\title{
BIODIVERSITY PLANNING FOR VICTORIA UNIVERSITY OF WELLINGTON'S KELBURN CAMPUS
}

Frances Mary Jean Forsyth

A thesis submitted to Victoria University of Wellington in fulfilment of the requirements for the degree of Master of

Science in Ecology and Biodiversity

Victoria University of Wellington

2016 


\section{FRONTISPIECE}

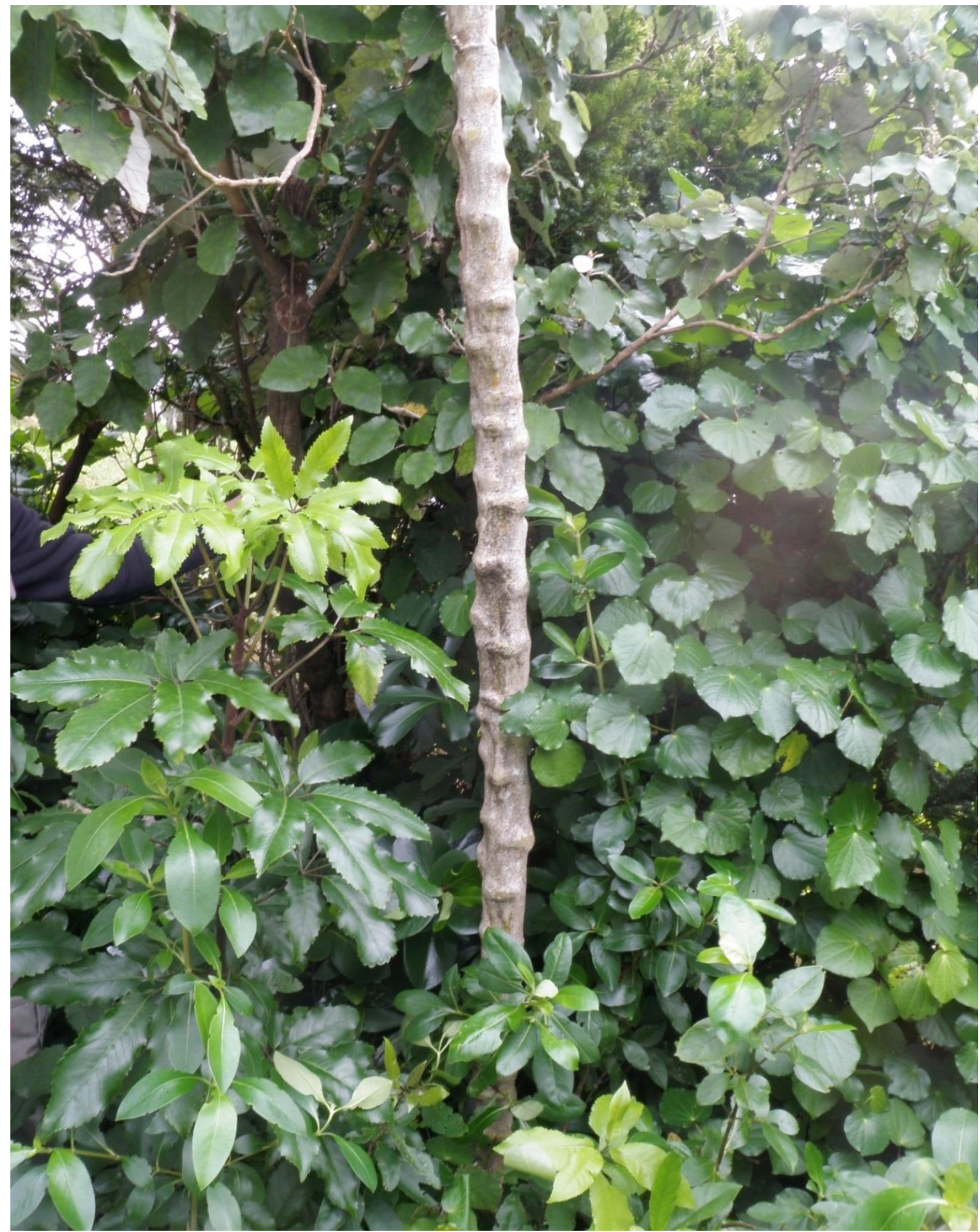

The stem of a lancewood (Pseudopanax crassifolius) and the able arm of research assistant Yong Tang centre left. 


\section{ABSTRACT}

Urbanisation changes the biotic and abiotic elements of natural environments irrevocably and almost always results in losses of indigenous species and habitats and the creation of new habitats. Humans are attracted to cities for social and economic reasons but put considerable effort into making life in cities more pleasant by creating urban green spaces where they can go, or which they can look at, to re-connect with the natural environment. Historically, large organisations and institutions, including universities, have also created park-like gardens for the benefit of their workers and students.

This research concerns the 3.87 ha of garden and wilderness green space areas on the Victoria University of Wellington Kelburn campus (New Zealand). Established on a steep hillside in suburban Wellington in the early 1900s it now lies along the boundary of the Central Business District. Effective management of the grounds has become a priority in order that increasing numbers of students and staff may get more benefit from the services they provide, and the natural capital of both the campus and the city can be enhanced. A management plan incorporating recommendations from this research could guide biodiversity and environmental enhancement of the campus. As well as supporting urban biodiversity, and students and staff, these enhancement actions will strengthen and improve relationships with stakeholders, raising the profile of the university and bring its biodiversity policies in line with local government.

For this study I measured tree frequency, density and species diversity on the Kelburn Campus and compared present day tree species richness with historic records for the campus, the Wellington Botanic Garden native forest remnants, and a local bush reserve. I also determined recruitment rates for campus trees. A total of 177 tree and shrub species were identified including plantings of 17 rare indigenous species. The overall diversity score was moderate (Shannon Weiner 3.023), and species richness on the campus had diminished from a high of 146 species in 1990 . Without intervention species richness is likely to fall even further given that 81 species are currently represented by four or fewer trees. Recruitment data for weedy non-local species (both introduced and non-local indigenous) showed that there were significant numbers of these species in most size groups from seedling to mature trees. This indicates that greater control of these species is required.

In the second part of the study I questioned members of the campus community about how they valued its green space, where they went and why, what they liked about their favourite 
places, and what they would like to see more or less of in campus green space. The results were, in general, consistent with the literature. Male staff were prepared to travel further than students to get to their favourite places and also showed a preference for exercise over relaxation; females showed slightly more preference than males for warm and sheltered spots, and students preferred relaxation and socialising over exercise as their reason for going to their favourite places. Access and seating were important and a large proportion of respondents wanted more warm sunny places and more birds. Large trees, native plants, flowers and lawns were also popular. These preferences were common to both students and staff.

Victoria University expects that the Kelburn campus population could double in size over the next twenty years or so. This will place pressure on campus green space, five percent of which was lost to development in 2015. Through my research I have demonstrated that biodiversity gains could be achieved through effective management of pest plant species and judicious planting. Permanent protection and planned management of campus green space and recognition of it as a capital asset will be important for retaining staff and students, and for improving relationships with neighbours and stakeholders. Specific recommendations include:

1. Research into the food value for birds of Pseudopanax hybrids compared with local Pseudopanax species.

2. Research into the likelihood of local Pseudopanax species being forced into local extinction by hybrid species.

3. Develop a pest plant management plan.

4. Determine which soils in campus green space areas have high biodiversity potential and select plants accordingly.

5. Determine the needs of the multicultural campus community for green space.

6. Promote green space areas to staff and students as destinations and provide explanatory information regarding the natural and other values of particular sites.

7. Enhance natural and infrastructural elements of green spaces with planting, pest control, seating, shelter, and canopy gaps for sunshine.

8. Review access routes for pedestrian comfort, future capacity, connectivity with the surrounding neighbourhood, and accessibility for variously 'abled' people. Give campus roads and pathways names and signage. 


\section{Acknowledgements}

This research would not have been possible without the support of many people to whom I owe a debt of gratitude. I wish to thank: Wayne Linklater and Stephen Hartley (supervisors), Campus Management Services and the Centre for Biodiversity and Restoration Ecology for the provision of a Biodiversity Planning Scholarship, Andrew Wilks from Facilities Management (for keeping me on track regarding what they wanted to learn from the research), Yong Tang (field assistant par excellence), Harry Thomas (for telling me about the scholarship), Kirsten Forsyth (for egging me on after seeing the scholarship advertised on a wall outside her classroom), Paul Blaschke (for being the third person to tell me I must do this and for providing encouragement along the way), Andrew Jensen (Grounds Manager, Bark Ltd. for providing archival material), Terese McLeod (for providing the background information about the maara kai), Mike Orchard (for helping with the identification of various trees and providing information about when they were planted), and Matt Velde (mapping advice and encouragement). 
Abstract. . V

Acknowledgements. viii

\section{Contents}

1. CHAPTER ONE: General Introduction and Overview .............................................. 1

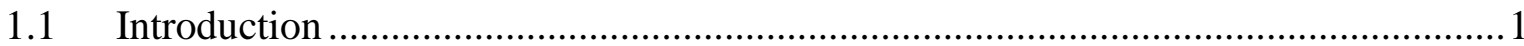

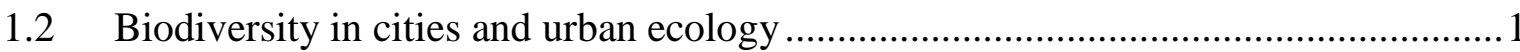

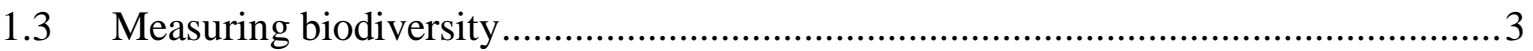

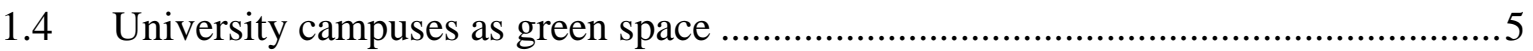

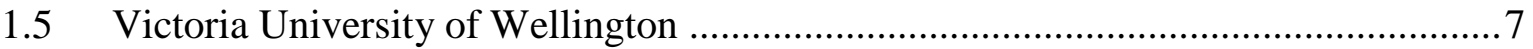

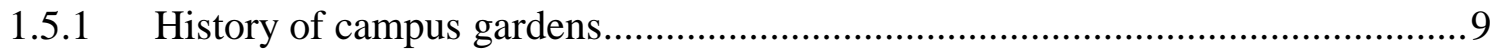

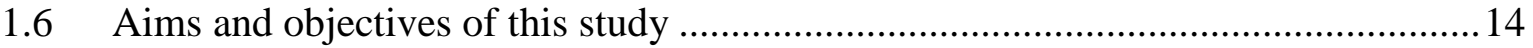

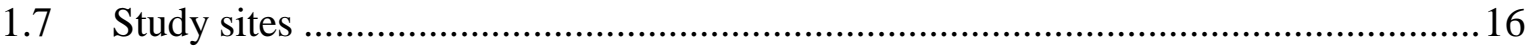

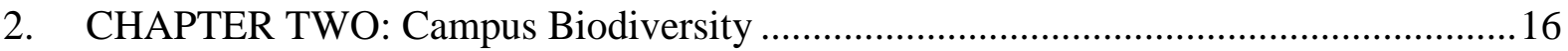

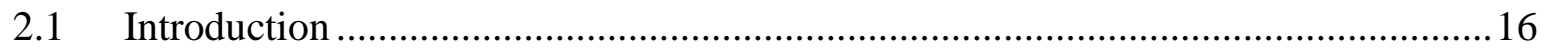

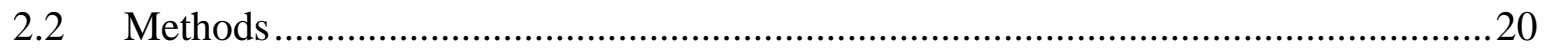

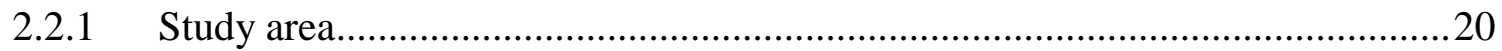

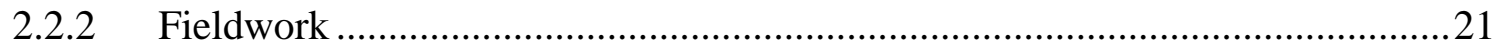

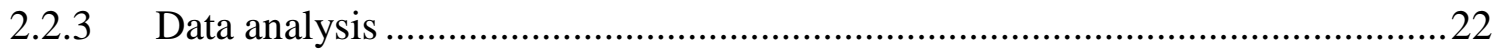

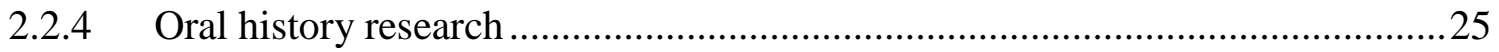

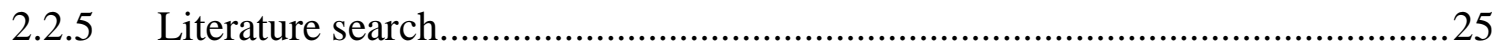

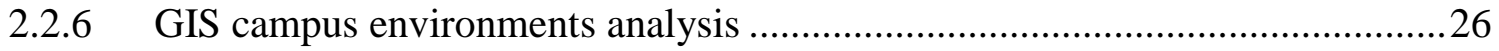




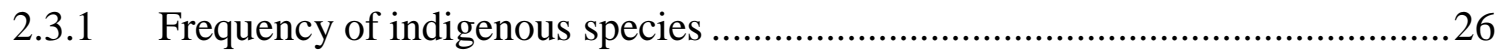

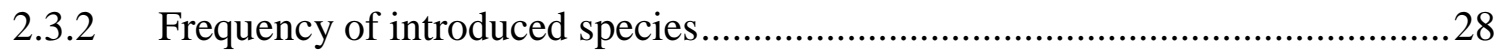

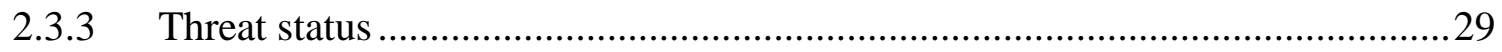

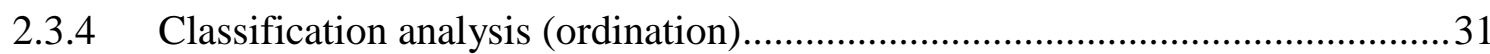

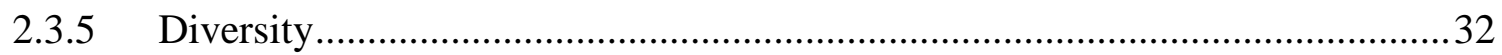

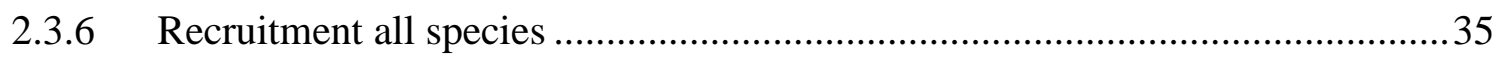

2.3.7 Change over time, history of campus species diversity .................................. 40

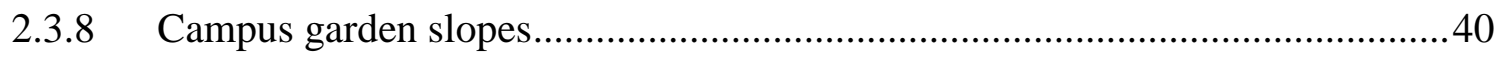

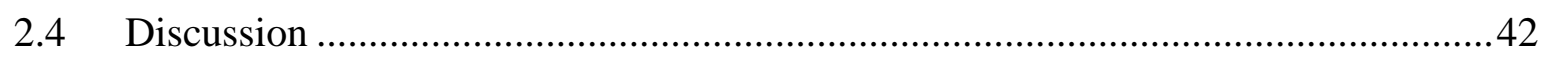

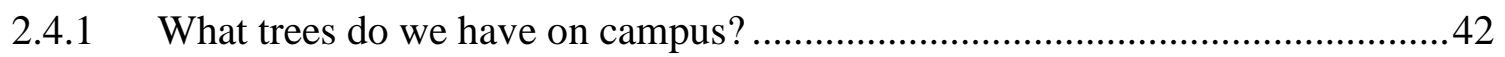

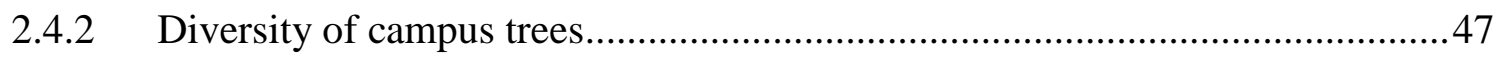

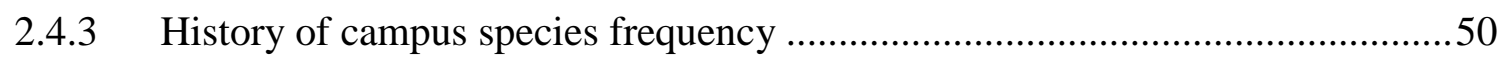

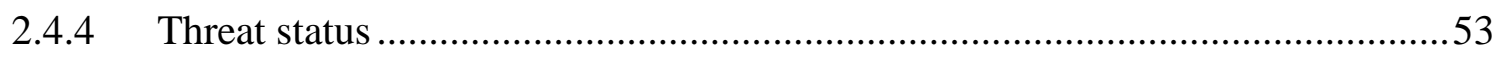

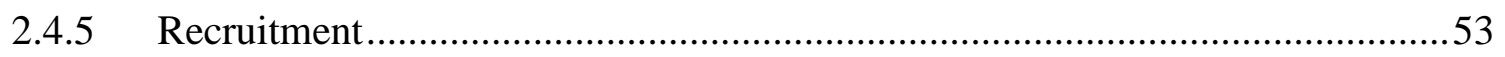

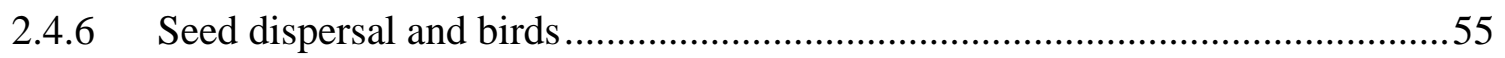

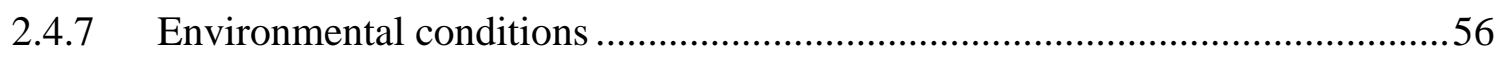

2.4.1 What might have been, Botanical Gardens forest remnants ............................56

2.4.2 What could be, Waimapihi Reserve restoration ...........................................57

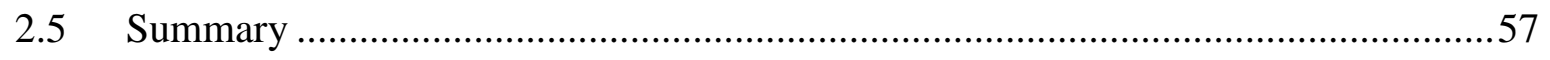

3. Chapter Three: Perceived Values of Campus Green Space ..........................................58 
3.1.1 The values of institutional urban green space .................................................58

3.1.2 Historical values attached to VUW campus ...................................................59

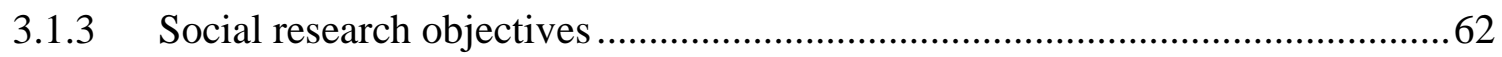

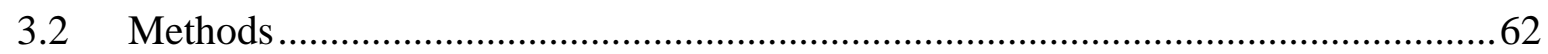

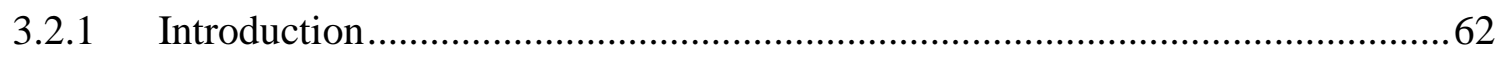

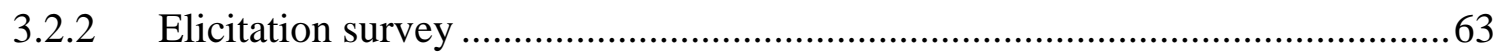

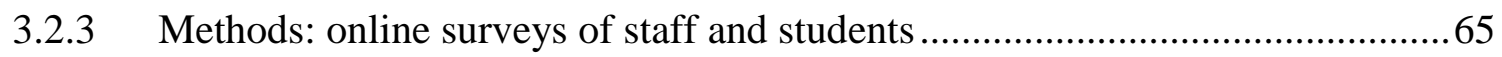

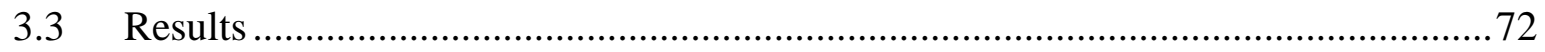

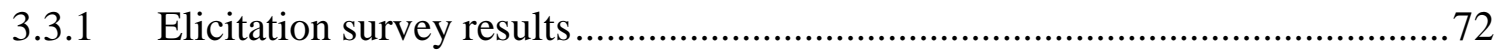

3.3.2 Staff and student online survey results ....................................................... 75

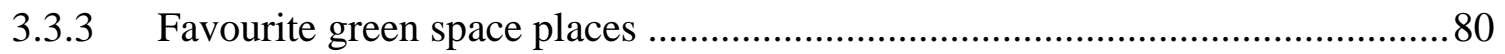

3.3.4 Wish lists- things that staff and students want more, or less, of ........................ 84

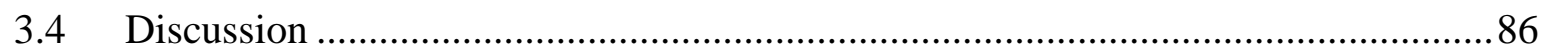

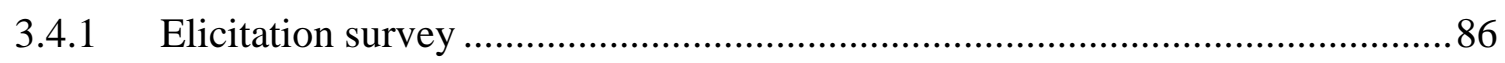

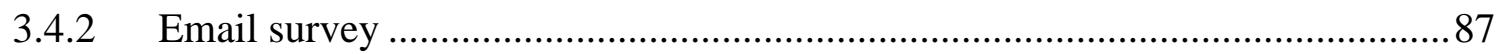

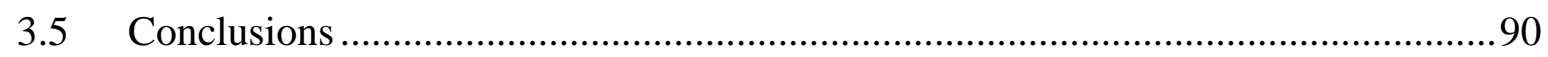

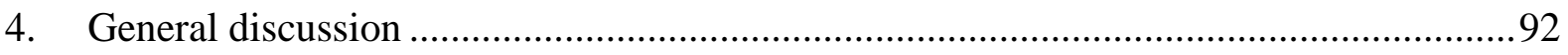

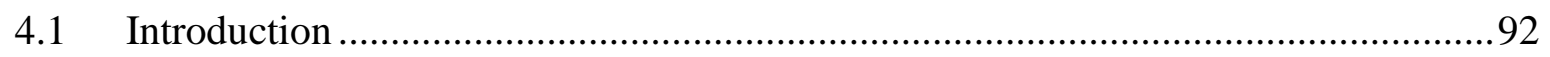

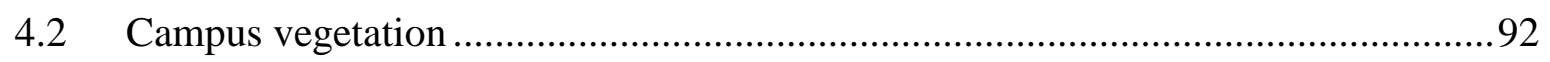

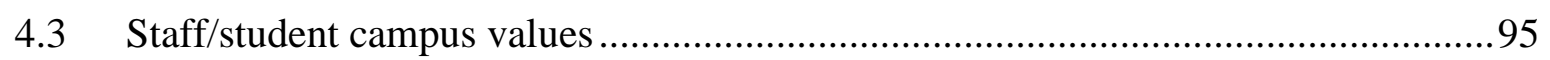




\section{APPENDICES}

1.1 All tree species recorded on the Kelburn campus between 1961-2015

1.2 Bark (grounds contractor) management zones

2.1 Inventory of all species occurring on the Kelburn

2.2 Species that occur only infrequently

2.3 Locations of campus plant collections

2.4 Tree species recorded from the indigenous forest remnants at Wellington Botanic Garden and Kelburn campus

2.5 Comparison of campus indigenous species with a checklist for Waimapihi Reserve, Aro Valley

3.1 Ethics Committee approval for an elicitation survey

3.2 Elicitation survey questions

3.3 Permission form for elicitation survey participants

3.4 Staff email survey questions

3.5 Student email survey questions

3.6 Ethics Committee approval for an email survey

3.7 Have your say tear tab poster for students

3.8 VIC News article

3.9 VUWSA Facebook page about the student survey

3.10 Staff/student favourite greenspace places

3.11 Distance staff are prepared to travel to their favourite greenspace 



\section{CHAPTER ONE: GENERAL INTRODUCTION AND OVERVIEW}

\subsection{Introduction}

Urbanisation results in losses of natural indigenous species and habitats and the creation of new habitats. However, humans appreciate and create urban green space, and indigenous species have a way of hopping back into town and joining in whether we want them or not. Although many of the species that are present in urban landscapes are generalists of both indigenous and exotic types (Müller et al. 2013) recruitment from urban forest remnants accompanied by judicious planting can improve diversity within regenerating urban green spaces. This means that there are biodiversity gains at both the local and regional scales which, if managed well, can result in resilient biotic communities that protect and conserve indigenous ecological values as well as contributing to human well-being, and to education about, and understanding of, indigenous biodiversity.

Just over half of the world's population live in cities, and this is expected to rise to $66 \%$ by 2050 (United Nations 2014). This means that urban ecosystems will be the main way that many urban dwelling people experience nature first hand.

\subsection{Biodiversity in cities and urban ecology}

People have been coming together in cities and towns for thousands of years. While they come together for social and economic reasons people still miss the natural environment of the countryside and wilderness, which, in the main, is destroyed when a city is developed. Historically, people have coped with their sense of loss by the development of private gardens and the provision of public parks and street trees. These soften the hard lines of the city and provide limited services such as shade, quiet, birdsong, food, fuel, beauty, and outdoor spaces to gather and exercise in. These, and other services including stormwater management and carbon sequestration are known as ecosystem services, a term popularised in the reports of the Millenium Ecosystem Assessment Group (Sarukhán et al. 2005).

In the meantime, some elements of the plant and animal communities that were present before the development of the city, remain and flourish. These are usually the generalist species, prolific and adaptable, common, and therefore frequently despised. 
These indigenous species, and others introduced by immigrants from distant climes combine to create highly diverse communities (Kühn et al. 2004; Müller et al. 2013; Van Kluenen et al. 2015)

Remnant pockets of indigenous vegetation and associated fauna may survive in ravines and on cliff-tops, places too difficult to develop. Other remnants may survive in public reserves or on private property where they can provide an instant garden, a living museum, or a living structure for the display of fashionable amenity plants.

The protection and enhancement of urban biodiversity is recognised not only as a way of making cities more liveable for humans (Foreman 2008), but also as a means for conserving and restoring the particular natural ecosystems that were present on city sites prior to development (Palmer et al. 2004; Pickett et al. 2011). The areas where cities develop are generally lowland, near estuaries or harbours, close to the resources needed to support the people and industry of the city. This means that biodiversity particular to such habitats is almost totally destroyed, and any remnants of the original ecosystems of the area are usually critically under- protected (McKinney 2002; Walker et al. 2007). Conserving urban biodiversity is also an important way to demonstrate to city-dwelling people the processes vital to human sustainability (Hostetler et al. 2011).

Those of us who are fortunate enough to live in Wellington City appreciate that although the original forest of the area is largely gone, a combination of early planning decisions and rugged topography means that there are now many areas throughout the city where development has not occurred and regeneration of the forest is taking place. In combination with city parks, urban gardens and a number of city and community forest planting enterprises, this regenerating forest now provides a valued green network across the city (Wellington City Council 2013). Many of these areas now have well-established forest, native bird populations, and also a degree of legal protection (Miskelly et al. 2005; WCC 2013). They also have varying levels of protection from the threats posed by pest plants and animals (Greater Wellington Regional Council 2009). One might say that they are on an ecological trajectory towards the re-establishment of some of the original ecosystems present before the forest was cleared. Or are they? 
Breaking down biogeographical barriers by importing plants from other countries and areas can result in damage to local ecosystems if those species become naturalised (van Kleunen et al. 2015). Managing the balance between recruitment and mortality of trees in urban forest is a key challenge for those wishing to integrate conservation, horticultural practise and landscape aesthetics (Manning et al. 2006; Muthulingam and Thangavel 2012). The cultural influence of introduced plants is strong, they remind immigrants of home, but for the children of those immigrants, and of the indigenous people, the introduced species come to represent home and even, perhaps, the identity of New Zealand (Park 2006; Meurk 2013). What would the New Zealand landscape look like without radiata pine and macrocarpa trees?

Urban ecological studies, although relatively recent in the history of scientific research, are increasingly informing the management of urban biodiversity (Foreman 2008; Pickett et al. 2011). If we are to be successful in our endeavours to maintain the natural character of our city through the growing green network we must continue to develop our understanding of the processes at play and communicate these to those charged with management of it (Alvey 2006).

As cities develop they destroy and modify indigenous habitats. However, in the wake of urban development there is demand for green space and leafy areas to provide cultural and recreational services (Meurk et al. 2013). New habitats are created in parks and gardens while modified natural habitats such as riparian areas, transport corridors and green belts may be managed not only as infrastructure, amenity and cultural assets, but also to encourage a high diversity of indigenous and exotic species.

\subsection{Measuring biodiversity}

Biodiversity is the variety of plant and animal life, and micro-organisms in the world and the ecosystems in which they are found. Species diversity is a widely adopted metric for assessing biodiversity (Chiarucci et al. 2011). Whittaker (1972) described measures to determine species level diversity. These were species richness, the Simpson Index, and the Shannon Wiener Index. Species richness is a simple count of species in a community, area or region. It does not take into account the abundance of species, or how common/rare a species is within a particular community. The 
Simpson Index is a similarity index and measures the abundance of each species relative to all others in the community, and is weighted on dominant species The Shannon Wiener Index shows both richness and abundance across the whole community. This makes it a useful measure for when you inventory an entire community in order to capture all of the rare/uncommon species, rather than just sampling the community. It is not practical to measure biodiversity across all species of plant, animal and microbe in a community so usually a proxy group is measured such as trees in a forest community or biofilms in a marine community.

Measurement of vegetation has been undertaken for several centuries now, and in a wide variety of permutations in order to explain the occurrence of both individual species and groups of species. Humboldt (1769-1859) described communities based on dominant species and believed that generally these communities could be understood in terms of the environmental conditions where they were found. His theories were based on careful plant specimen collection and cataloguing, along with records of environmental factors (Stohlgren 2007). This led to a strong focus amongst ecologists on biogeography and the local, regional and global distribution of plants. At the same time botanists and ecologists began observing, measuring and recording changes in plant communities on a variety of scales and developing theories around areas such as species interactions, relative abundance, species succession and community equilibrium (Real and Levin 1991).

Although the above techniques for measuring diversity and the definitions of biological diversity are widely used there is still some disagreement about what they really measure and how effective they are for making that measurement (Hurlbert 1971, Poole 1974; Ricotta 2005; Chiarucci et al. 2011). One issue is that sampling cannot completely replace a full inventory. However, an inventory can be onerous or even impossible to achieve. Another issue is that there is a difference between the diversity of, for example sales figures or the characters and type faces of alphabets; and the diversity of living things like plants or animals. This is especially so when the diversity of trees is being used to reflect biodiversity as a whole in that particular community.

It is desirable when assessing vegetation to know more than merely the number of species present. Measures of species abundance and their abundance relative to other 
species are useful, as are also measures of recruitment from seedlings to saplings and canopy species. This is especially so in large gardens such as a university campus where there is a combination of planting and natural recruitment occurring, including hybridisation, and the immigration of invasive exotic, and non-local indigenous, species. By measuring and analysing all of these things at the Victoria University Kelburn campus we can come to some understanding of what is in the gardens, what is missing, the contribution of amenity trees, and the trajectory of the species mix. Then we will be able to make decisions regarding the future management of the gardens.

\section{$1.4 \quad$ University campuses as green space}

Increasingly, large corporate bodies in both the public and private sectors are appreciating their role as managers of biodiversity amongst other things usually considered e.g. financial bottom line, health and safety, energy efficiency, corporate social responsibility (Houdet et al. 2012; HEFCE 2013; Overbeek et al. 2013). In 2006 the global business community was officially asked to contribute to the objectives of the Convention on Biological Diversity (CoP 8 decision VIII/17) and in 2010 a global study initiated by the G8 and five major developing countries (TEEB for Business) developed key action points for businesses with regard to biodiversity and ecosystem services. Not for profit organisations have been a part of the new management approach by developing frameworks to enable positive impacts for corporate land management practices e.g. the Corporate Wildlife Enhancement Programme run by the Wildlife Habitat Council (USA) and the Biodiversity Benchmark run by the Wildlife Trusts (UK).

As well as there being opportunities for corporate volunteer days there are now many conservation projects on business and industrial estates involving species and habitat protection, provision of 'stepping stone' habitat and consciousness raising (Snep et al. 2009; Snep et al. 2011; Serret et al. 2014)

Campus biodiversity is recognised as a marketing draw card by many universities around the world. This is an extension of the promotion of leafy campus environments to encourage students and academics to choose a particular University for study or a career. The University of Northampton recognises both the marketing 
and ecological values of campus biodiversity and has created a web-based tool to measure plant diversity on British campuses (HEFCE 2013). Such tools are being incorporated into university sustainability plans around the globe, along with energy and water efficiency, waste minimisation, sustainable construction and design, and sustainable procurement policies.

The University of Puerto Rico campus botanical garden, as with most campus gardens, consists of many parts. It offers multiple programmes, including for the public, encompassing recreation, collection, research, ecology, conservation and invention (Corner 2005). The university decided in the late twentieth century to capitalise on the development of a new light rail line for the city and make the campus gardens a destination. Known as the San Juan Jardín Botanico it covers 120 ha and contains the Urban Forest of the New Millennium, an urban forest conservation project.

Ahmedabad University in Gujarat State, India caters to over 200,000 students and has an area of 105 ha. Plants across this campus have been sampled revealing the presence of 451 species of angiosperms, two gynosperms and three pteridophytes (Modi and Dudani 2013). The survey identified the campus as one of the most important green belts of Ahmedabad City (population 7 million).

Campus gardens can also be rich in plant species as well as havens for staff and students. Thirteen campuses within five central urban districts in Guangzhou, China (population 2.13 million) were included in a major forest diversity study undertaken by Jim and Liu from the University of Hong Kong (2001). The study was of parks, street trees, and campus gardens that were greater than one hectare and which totalled more than 220 ha. Campuses had the greatest species richness (215) of all of the sites surveyed and featured many fine indigenous trees.

Auckland Unitec's Mt Albert campus (55 ha) is the site of an arboretum project that has involved the identification and cataloguing of over 2,000 trees and shrubs. As research assistant Daisy Tang put it "it is important to remind people of the great features that are right here" (anon 2013). The arboretum has its own website which is the main public interface for the arboretum. Landscape Architecture Senior Lecturer Penny Cliffin points out that the trees are not only a record of the natural environment 
but also provide evidence of human history in the area. The project has also developed a self-guided walk with plant labels linked to a phone app that links to the website (anon 2015).

Massey University has also initiated an arboretum project at their Palmerston North Campus. The Massey project is listed with Botanic Gardens Conservation International, the world's largest plant conservation network with 500 members in more than 100 countries (www.bgci.org). The Massey University grounds, which are listed as a New Zealand Botanical Garden, are said to have 11,500 varieties of plants and trees (www.massey.ac.nz).

\subsection{Victoria University of Wellington}

The Kelburn campus of Victoria University lies on a hill on the western side of the city's Central Business District (Figure 1.1). This provides staff and students with fine views of the city and harbour, but also leaves them and the campus exposed to the winds for which the city is famous.

Victoria University has extensive planted gardens and areas of regenerating forest, and a growing awareness of the biodiversity potential of urban landscapes and the need to evaluate the ecological and social outcomes of biodiversity management planning and implementation. A number of ecological research projects on urban themes have been supported by the university in recent years including: ecological foot-printing, ecological resilience and urban design, community uptake of urban greening initiatives and the effects of this on the well-being of people, seedling survival in urban re-vegetation projects, and urban human-wildlife conflict. A biodiversity plan for the university's main campus based on sound ecological principles has the potential to:

- Enhance biodiversity values within and outside the campus boundaries

- Complement and enhance local government pest management strategies

- Enhance the value of the campus vegetation and fauna for teaching and amenity purposes, and

- Generate research opportunities for staff and students. 


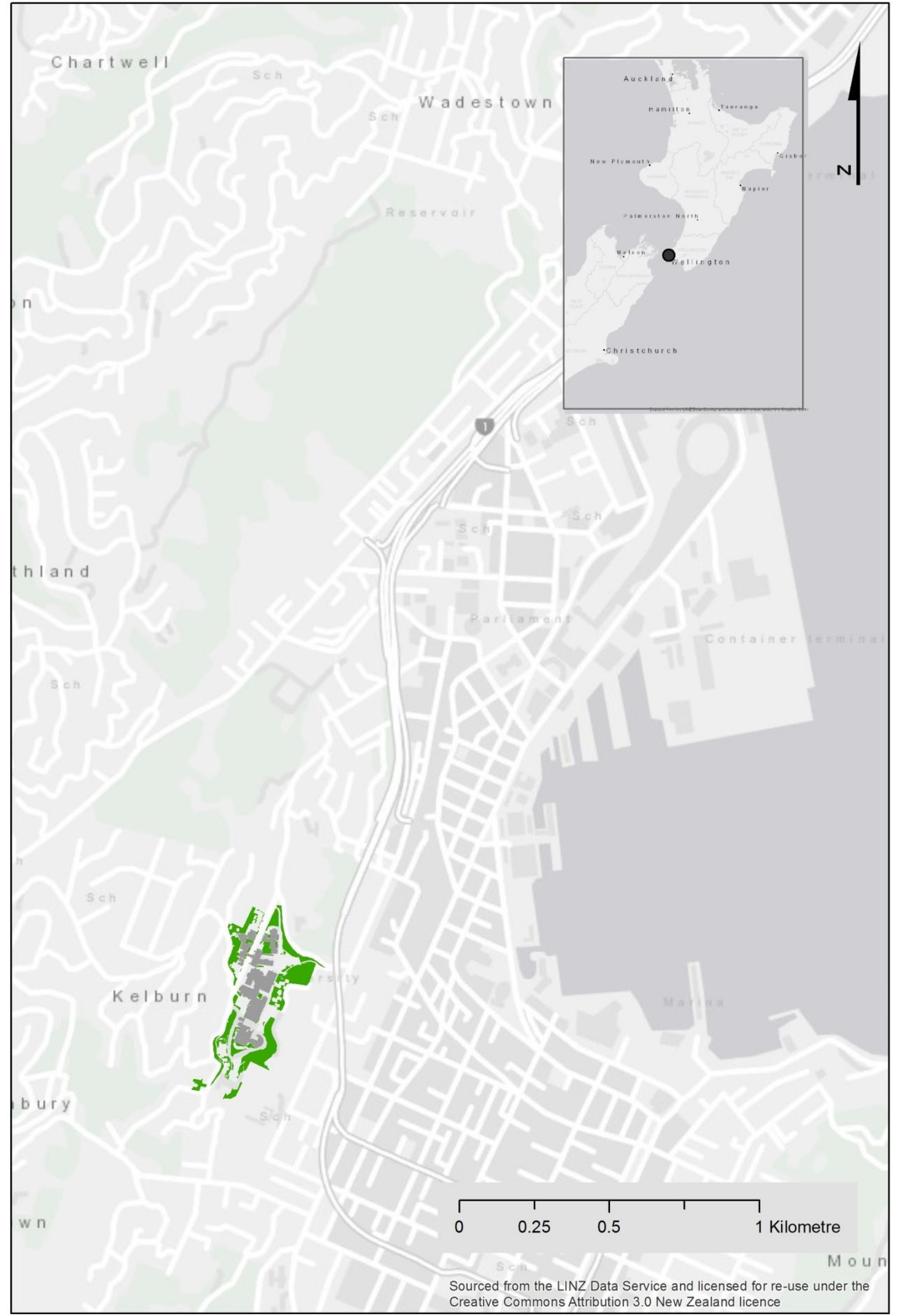

Figure 1.1: Location of the Victoria University of Wellington, Kelburn campus. The campus gardens are shown in green surrounding the main buildings of the campus. 
Research into the biodiversity values and associated issues of the university campus will have value for Victoria University of Wellington (VUW) in terms of its institutional responsibility to be a 'good neighbour' and as a 'collaborator' with local government. It should also inform future management of campus green space to the benefit of staff and students who work and study there.

Victoria University is a major land manager in the centre of Wellington. It has an environmental policy that includes a commitment to environmental protection, raising environmental awareness and providing community leadership (Policy document provided by Facilities Management Policy Group). It is university policy to exceed environmental standards set by local, regional and central government, actively seek to enhance the biodiversity of natural areas and investigate opportunities to introduce more natural areas into the built environment.

Wellington City has a strong focus on biodiversity management, and the City Council is part of a global network known as the Biophilic Cities Project. The main tenet of that project is to increase the connection between people and nature (www.biophiliccities.org) In raising a biodiversity planning scholarship the VUW Centre for Biodiversity and Restoration Ecology recognises that the university should be a part of that. The university's environmental policies to take responsibility for sustaining campus biodiversity and enhancing ecosystems are strengthened by its engagement in community networking and partnerships.

\subsubsection{History of campus gardens}

In 1901, Charles Pharazyn, a Wairarapa farmer made the Council of Victoria, one of the four university colleges of New Zealand an offer of $£ 1,000$ if it chose to establish a campus in Kelburn (Barrowman 1999). The college therefore acquired just over six acres (2.6 ha) in Kelburn and work began immediately to level the steep site in preparation for construction of what was to become known as Hunter Building. Soon after this tennis courts and a pavilion were developed beside the building (Plate 1.1) but it was recognised that "much turfing, grassing, and tree-planting is still necessary to make them sightly ... the grounds of a University College ought to be attractive, but ours as yet are far from that" (Annual Report for 1909 AJHR 1910 E7 cited in Barrowman p16). At about this time the campus earned the title 'the Old Clay Patch' due to the high dust levels from the clay paths. 


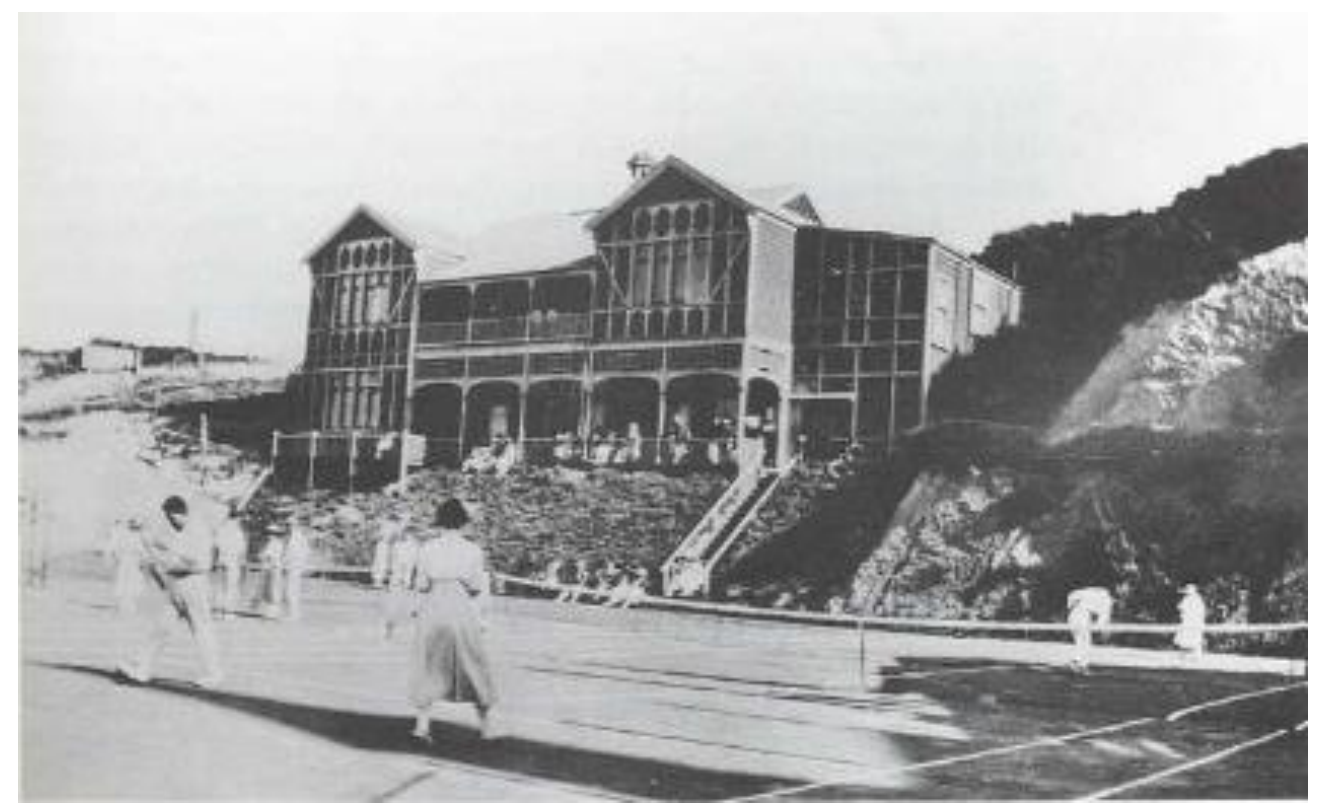

Plate 1.1: Tennis courts, now the site of the Student Union building, with the pavilion behind and bare rock banks typical of the era. The Student Union Building was built on this site in 1960 and the pavilion demolished. VUW 2/236 1921-22

This was the extent of major improvements to the grounds until the late 1920s when the Salamanca Road/Kelburn Parade intersection was widened and a clay bank there was replaced by the sloping lawn and shrubberies that we see today (Plate 1.2). 


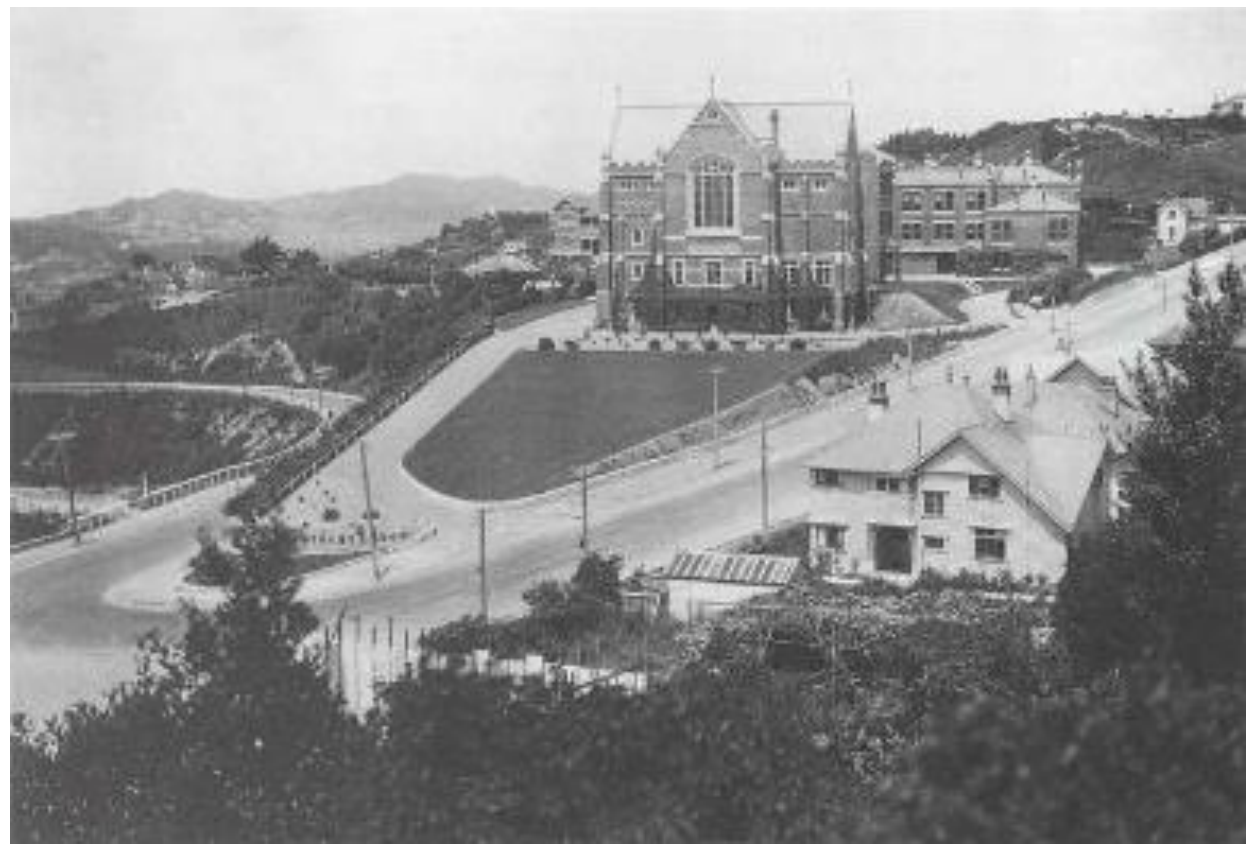

Plate 1.2: The Hunter building and recently landscaped campus entrance in the early 1930s. VUW 2/204 Crown Studio

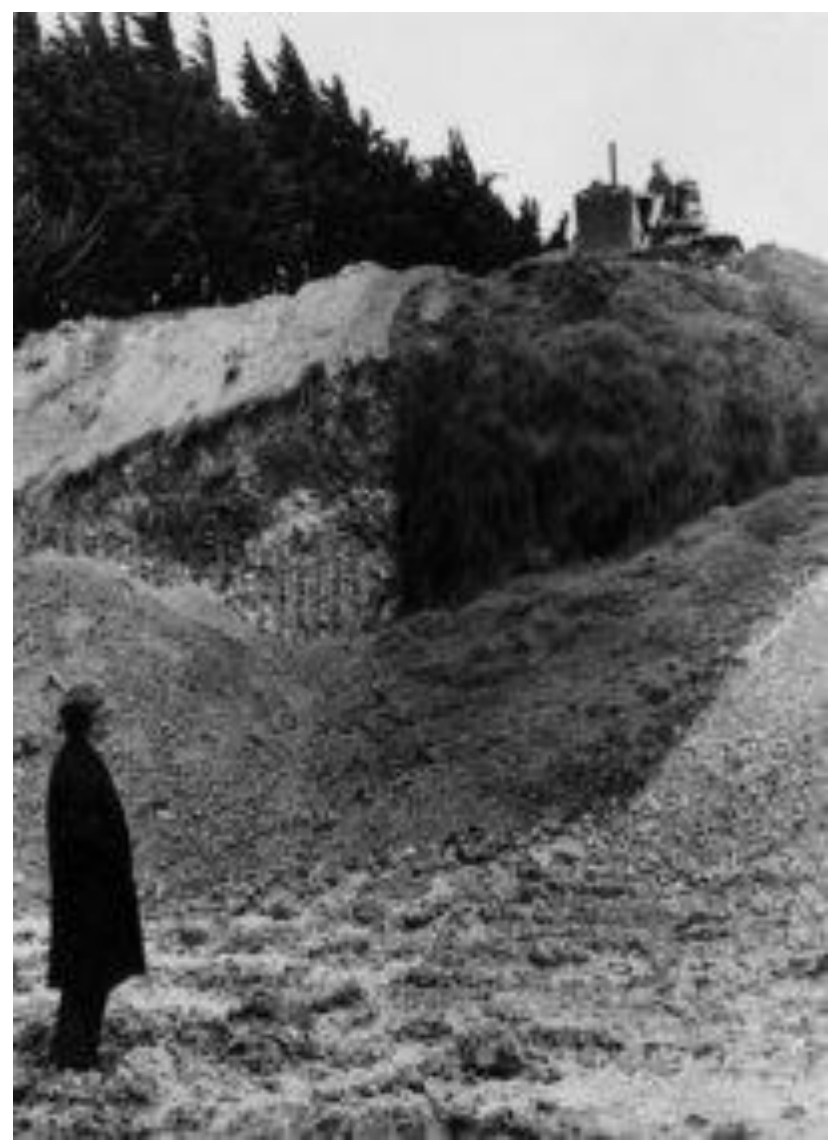

Plate 1.3: Sir Thomas Hunter, first Principal of Victoria College watching the levelling of land for the university in November 1948. ATL C23836

The simple approach of carving building platforms from the rock and then attempting to landscape the rocky perimeters of new buildings (Plate 1.3) was repeated again and 
again throughout the twentieth century and continues today with the construction of the Gateway Project between Kelburn Parade and the Cotton building.

From 1961 to 1982 the position of Grounds Superintendent was held by a Quaker by the name of Joe Short. Joe was a qualified gardener with a National Diploma of Horticulture. As well as a team of gardeners and labourers Joe had greenhouses and plant nursery areas where plants were raised for use on the campus. During his term at the Kelburn campus Joe compiled a list of plants that were growing on the campus (Appendix 1.1). The list includes 55 indigenous trees and large shrubs, including 21 species no longer present today. It also includes 133 introduced species, including 106 species no longer present today.

Fill from building excavations went into nearby gullies creating flat sites unsuitable for building. These were used for the Salamanca Road tennis courts and the Boyd Wilson field. Above the Boyd Wilson field the rock was excavated in tiers that remain evident today. The thin soils that developed under a gorse cover on these tiers were planted in the 1980s with kanuka (Kunzea ericoides) and other hardy colonising trees (pers comm. Mike Orchard, Grounds Superintendent 1986-1996 11/04/2015). Steep banks around the campus, particularly those which were part university owned and part road reserve such as the banks between the Hunter building and Salamanca Road, were planted initially with hardy, coastal, indigenous species such as pōhutukawa (Metrosideros excelsa) and many large specimens of this species are still present in the modern gardens. The natural distribution of pōhutukawa is north of a line between Taranaki and the Mahia Peninsula in the North Island of New Zealand, and in the Three Kings Islands. The Salamanca Road pōhutukawas were later underplanted with Camelia cultivars. 


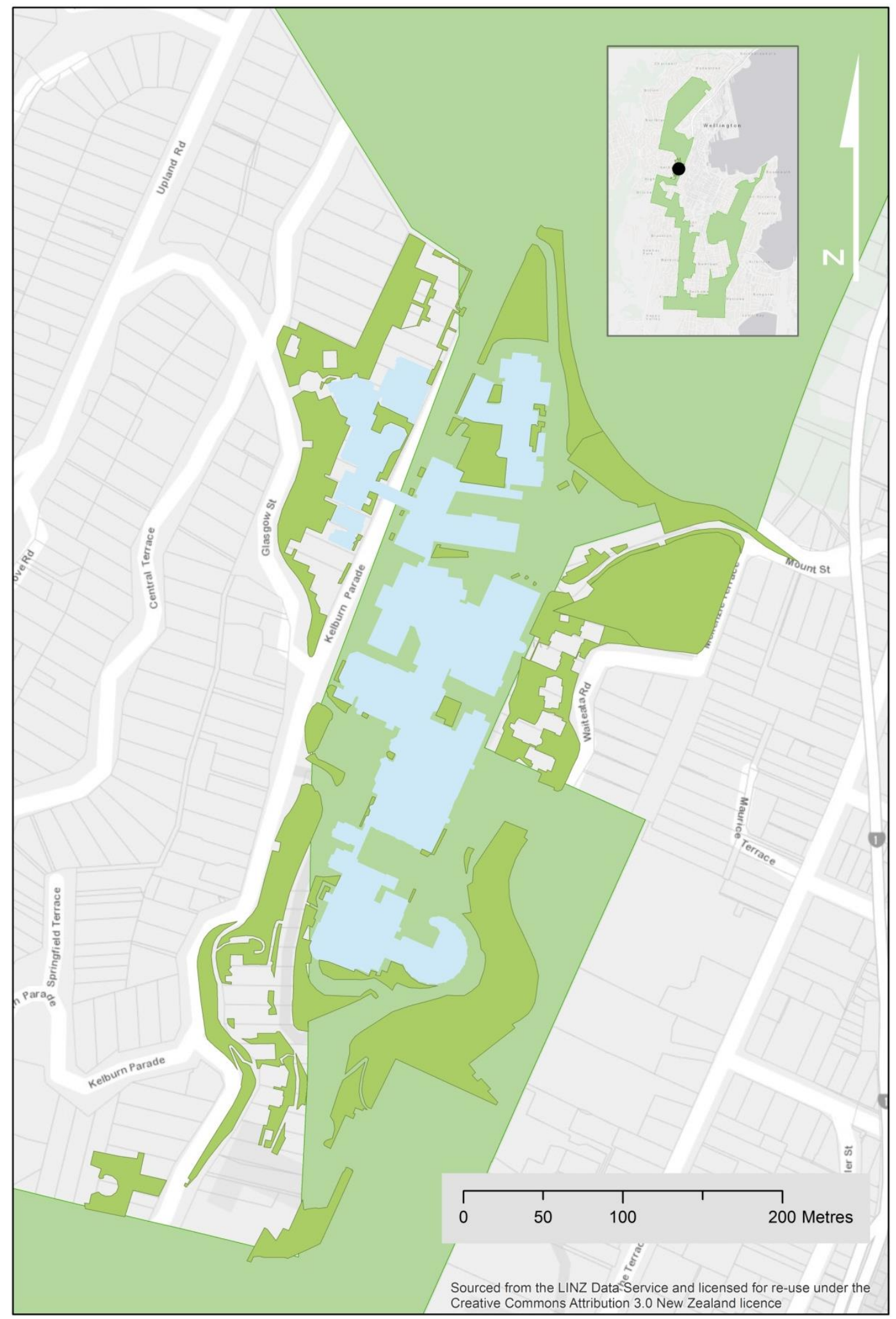

Figure 1.2: The relationship of the existing Victoria University of Wellington, Kelburn campus gardens (mid green shading) and main campus buildings (pale blue) to the area set aside as Town Belt in 1841 (light green shading). The insert, top right, shows the 1841 Town Belt in its entirety with Wellington Harbour top right and the position of the VUW campus. 
In 1841625 ha of land surrounding inner city Wellington was reserved by the Crown for a green belt, known as the Town Belt. This was a result of planning by the New Zealand Company which ran a private colonisation scheme from Britain in the mid 19th century. The company secretary John Ward wrote "It is indeed desirable that the whole outside of the Town, inland, should be separated from the country by a broad belt of land which you will declare that the Company intends to be public property on condition that no buildings be erected on it." (Cook 1992). The purpose of this land was for public recreation and to secure the beautiful appearance of the city. In 1873 when the Crown conveyed the land to Wellington City Council the Town Belt area as stated in the Deed was 429.5 ha. Land continued to be lost from the Town Belt including 2.4 ha in 1901 for the establishment of Victoria College, Kelburn (Figure 1.2). A further 5.4 ha was added to the Kelburn campus in 1949 (Wellington City Council 2013). In 2013 only 389.68 ha remains of the land subject to the 1873 Town Belt Deed. However, an additional 130.34 ha of relatively contiguous land is owned by Wellington City Council and managed as Town Belt. A present day remnant of the Town Belt, Kelburn Park/Kumutoto Reserve lies immediately to the north of the Kelburn campus. To the south lies land which was previously Town Belt and is now owned by the Crown and managed by the Ministry of Education. Wellington City Council is negotiating for the return of the undeveloped part of this block into the Town Belt.

Kelburn Park and Kumutoto Reserve are managed by the City Council to return the woodland to podocarp broadleaf forest, to retain and enhance the village green character of the sportsfield and croquet club, to retain the existing character of amenity and pohutukawa plantings, and to protect and manage heritage cabbage trees between the sportsfield and Salamanca Road. Students and staff from Victoria University are actively involved in research and restoration activities in Kumutoto Reserve. The Devon/Abel Smith area is to be managed to return to podocarp broadleaf forest. There is no active volunteer restoration group working there.

\subsection{Aims and objectives of this study}

The purpose of my study is to develop a biodiversity management plan for Victoria University's Kelburn campus structured around ecological dimensions but with a strong social salience. 
1. Determine campus biodiversity values:

1.1. Determine what is there and what is not there by creating an inventory all of the tree species on campus,

1.2. Identify the common and uncommon species, any plant collections, and threatened species on campus,

1.3. Determine the diversity values on campus by comparing the vegetation in the various areas on the campus,

1.4. Determine what plants are successfully recruiting and what this means for the future of the of the vegetation under the current management regime,

1.5. Show the relative change of campus vegetation over time by comparing the vegetation on the Kelburn campus with historic inventories for the campus,

1.6. What might have been, compare campus vegetation with local indigenous forest remnants in the nearby Botanical Gardens,

1.7. What could be, compare campus vegetation with a local community forest restoration,

1.8. Discuss environmental factors affecting plant success.

2. In order to determine the value placed on campus green space by the university community I wanted to identify where staff and students liked to go during their time on campus and how far they were prepared to travel from their usual work place to get there. I was also interested to know what were the significant influences on the use of campus green space and if gender made any difference to choices. Finally, I wanted to know whether the current campus green space meets staff and student expectations.

3. General discussion:

3.1. Identify opportunities for enhancing campus biodiversity

3.2. identify opportunities for utilisation of campus green space as an educational resource 
3.3. Show the contribution that campus natural capital makes towards achievement of the Victoria University sustainability policy and the biodiversity objectives of Wellington City,

3.4. Determine how to optimise campus community expectation with amenity and biodiversity goals.

This information is presented alongside historical information regarding the development of the built landscape of the Kelburn campus. Together with the results of my fieldwork and surveys this will be used to show how the current biodiversity values for the gardens came about.

\subsection{Study sites}

Trees were identified and measured across the Victoria University of Wellington (VUW), Kelburn campus (Figure 1.1 ). The geographic extent of the survey work was limited to areas managed by the grounds maintenance contractor (Appendix 1.2) .

\section{CHAPTER TWO: CAMPUS BIODIVERSITY}

\subsection{Introduction}

The continued decline of biodiversity (plants, insects, animals and their habitats) is a matter of serious global concern (Horwich and Kretsch 2015). The current global rate of growth of urban areas is unprecedented and because urbanisation mostly occurs at the boundaries of land, river and sea the biodiversity effects are disproportionately large (Gaston 2010). However, ecosystems that support biodiversity provide humans living in cities with vital services such as removal of pollution and carbon from the air, the interception and infiltration of rainfall, shading and cooling of buildings, improving public health, and providing beauty and joy (Horwich and Kretsch 2015). For example the replacement cost of London's 8.4 million trees in terms of the ecosystem services they provide has been calculated as being $£ 6.1$ bn (Rogers et al. 2015). In the Rogers et al. report institutional trees in London, including university 
campuses were calculated as having an amenity value of $£ 2.7$ bn or $6 \%$ of the total value of Greater London's trees. This makes the protection, conservation and restoration of remnant biodiversity in cites absolutely vital. We need to incorporate nature into our cities in a way that supports them rather than replacing them (Dolesh 2014).

Assessing and monitoring biodiversity is important in order to determine any changes that might occur to an ecosystem over time as a result of management or natural disturbance. Because biodiversity is so complex, involving plants, animals, insects, microbes etc assessment can be made at a number of scales. There are a number of difficulties involved with measuring biodiversity of both a conceptual and practical nature (FAO 2010). Gillison et al. (2013) found that vegetation structure (mean canopy height, basal area and leaf litter depth) was one of several assessment indicators that could be used to accurately predict animal diversity. The London iTree study of Rogers et al. above also used a variation of this vegetation structure proxy in order to determine biodiversity values.

When the Victoria College of the University of New Zealand as it was known first established a campus in Kelburn the site was considerably smaller than it is now. In 1949 the university was given 13 acres (5.26 ha) of the Town Belt by the government (Barrowman 1999). This land was to the south of the existing six acre (2.43 ha) campus at that time which included the Hunter, Old Kirk and Robert Stout buildings. The university also purchased a number of residential properties on the western sides of Kelburn Parade and Waiteata Road and on Fairlie Terrace.

The current extent of campus gardens was, until the summer of 2014-2015, approximately 3.85 ha. Approximately 0.21 ha of garden was lost when excavations for a new building were undertaken. The gardens are made up of a large number (more than 60) of areas divided by buildings, paths and roads, and ranging in size from several square metres to over seven thousand square metres. Only rarely were these on relatively level accessible ground, and those blocks that were, generally comprised strips beside buildings and often contained only a small number of hardy, cheap trees and shrubs such as cabbage trees (tī kōuka, Cordyline australis), fierce lancewood (Pseudopanax ferox) and the ubiquitous pōhutukawa. 
Many of the more botanically interesting species were hidden amongst other trees, at the bottom of high retaining walls or up steep banks far from any path. Some of these interesting trees were under threat from gardeners tidying up, kaka ripping off their bark or the weight of large, leaning brush wattle trees. Not to mention the mass removal of trees to make way for a new building.

Objectives:

1.1. Determine what is there and what is not there by creating an inventory all of the tree species on campus,

1.2. Identify the common and uncommon species, any plant collections, and threatened species on campus,

1.3. Determine the diversity values on campus by comparing the vegetation in the various areas on the campus,

1.4. Determine what plants are successfully recruiting and what this means for the future of the of the vegetation under the current management regime,

1.5. Show the relative change of campus vegetation over time by comparing the vegetation on the Kelburn campus with historic inventories for the campus,

1.6. What might have been, compare campus vegetation with local indigenous forest remnants in the nearby Botanical Gardens,

1.7. What could be, compare campus vegetation with a local community forest restoration,

1.8. Discuss environmental factors affecting plant success. 


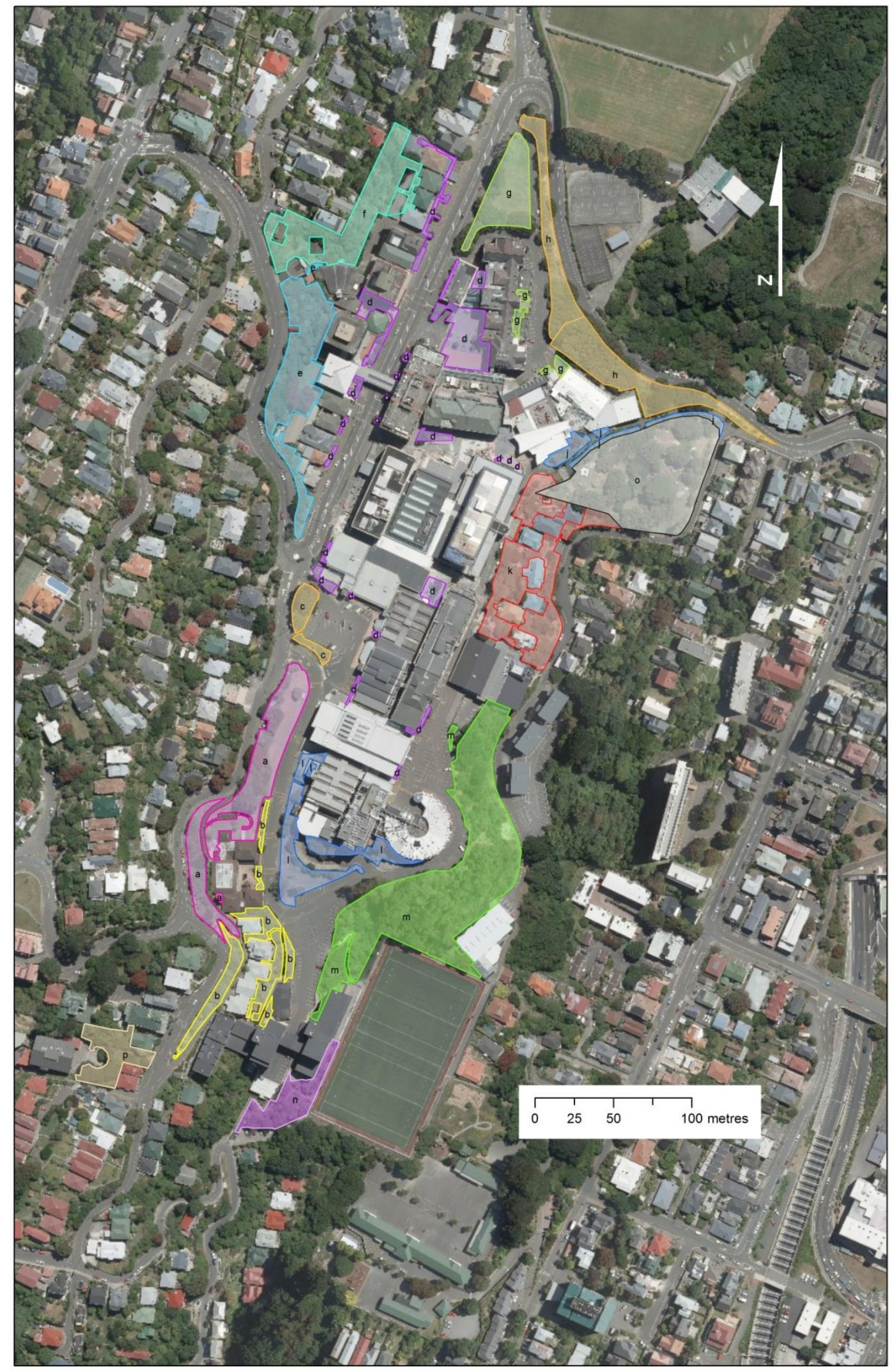

Figure 2.1: Kelburn campus and the fifteen vegetation blocks surveyed for this project. Each block is colour coded and labelled with the block code. Note that some blocks comprise multiple areas while others are one self-contained unit. 


\subsection{Methods}

\subsubsection{Study area}

The tree biodiversity study was conducted on the Kelburn campus of Victoria University of Wellington, New Zealand (Figure 1.1). A 3.87 ha area of the Kelburn campus formed the extent of the study area (Figure 2.1). The Kelburn campus lies at the boundary of the Wellington central business district and the suburb of Kelburn and dates from 1901.

Although Victoria University has an extensive property portfolio in Wellington the study area was determined to be only that which has extensive university controlled gardens. The day to day management of these gardens has been contracted out since approximately 1998. These areas were selected because the university wishes to know more about what is there, the effects of management, and how the gardens might be managed differently in the future.

I had been asked by Facilities Management, the university department that manages the contract for the garden maintenance, to make an inventory of what was there, including identifying rare and unusual plants. Ecologists studying vegetation do not always inventory every single plant at a site. Instead they tend to save time and energy by taking samples from plots and extrapolating the data. Sometimes, all that is collected from a survey is a plant checklist with no indication of the abundance of species or the composition of the canopy. Although the phrase urban forest is considered to include all woody vegetation in a city (Nielsen et al. 2014) Nielsen and his colleagues found that inventories tended to focus on individual street trees, although this was changing. Forty six of the 57 papers they reviewed involved direct measurements, and the information that was most commonly collected was species, size, DBH and crown size. The first three parameters provide useful information about a vegetation block, while crown size is more relevant to street tree health, where aesthetics, and shade qualities may have a higher priority. Probably because the majority of studies are of street trees recruitment from seedlings is not usually recorded.

A study by Jim and Liu (2001) is unusual in that information was collected on all trees in urban parks and temples (43,988 trees), all street trees (46,967 trees), and 
samples from fourteen college and university grounds (24,185 trees). As with other studies much of the information collected related amenity characteristics (shade, aesthetic and environmental considerations). However, emphasis was also given to determining the contribution introduced plants made to urban forests, particularly from an amenity perspective, and also to natural recruitment of indigenous species. This made me more confident that my choice of survey methods would yield useful information for the management of the Kelburn campus.

\subsubsection{Fieldwork}

In order to determine the current diversity values for the campus vegetation I undertook field work to collect data between December 2013 and October 2015. A field assistant measured trees while I identified them and recorded measurements and other relevant information.

The campus terrain, and in places the dense tree canopy, made it too difficult to divide the campus into a grid pattern and because the GPS unit often showed a large margin of error of \pm 12 m a decision was made to divide the campus vegetation into blocks with topographically defined boundaries. These blocks and boundaries were useful units of classification because they are also used by the gardeners to demarcate work areas and the level of maintenance applied.

Campus green space was divided into 56 blocks based on topography and landscape features such as pathways, buildings and roads. These included blocks on steep slopes ranging in size from $c .1,000-7,500 \mathrm{~m}^{2}$, to small strips alongside buildings and paved courtyards with amenity planting. The Mount Street cemetery, which is privately owned, but maintained by the university contractor, is contiguous with the Kelburn campus, and was also surveyed.

All trees that were equal to or greater than two metres in height were identified, measured and marked during a period between February 2014 and February 2015. The majority of trees were identified to species level either in the field or at the data entry stage. For a small number of trees identification to species level was not possible because they did not have visible reproductive organs at the time of measurement. Plant names used were those current in the New Zealand Plant Conservation Network database (www.nzpcn.org.nz) for indigenous New Zealand 
species, and the Integrated Taxonomic Information System (www.itis.gov) and the Australian Plant Name Index (www.anbg.gov.au/databases/apni-about/) for exotic species. The naming for Kunzea spp. follows the pre de Lange (2014) revision.

Tree height was estimated by eye and this measurement system was calibrated by measuring a number trees each week using an Abney level and tape measure.

Diameter at breast height $(1.3 \mathrm{~m})$ was recorded. Where trees had multiple stems the number of stems was counted and recorded. The largest, smallest and medium sizes of stem were then measured and recorded so that an estimate of total diameter at breast height could be calculated (Muthulingam and Thangavel 2012). Each tree that was identified and measured was then marked with a pink paint dot so that no tree was recorded more than once.

The five most prevalent groundcover/seedling species present on the ground beneath each tree were also recorded but not ranked for frequency.

\subsubsection{Data analysis}

The data from 5,967 trees was amalgamated from the original 56 blocks into 15 blocks for ease of analysis (Table 2.1). These 15 blocks were based on aspect and topography, maintenance regime, and garden plot size. Obvious collections, such as the off-shore islands collection (Block j), were kept together. For mapping purposes each block comprises one or more polygons. 
Table 2.1: List of the 15 Kelburn campus vegetation blocks (Figure 2.1), their codes for identification purposes and their area. Note that there is no Block i. Vegetation totalling about 0.21 ha from all of Block c, approximately half of the north end of Block $a$ and the northern part of Block I was removed during the summer of 2014/15 prior to the construction of a building to house the Scholl of Biological Sciences.

\begin{tabular}{|c|c|c|}
\hline Block Description & Block Code & Block area $\left(\mathrm{m}^{2}\right)$ \\
\hline Music School north and west slopes & a & 3,238 \\
\hline Music School south and east slopes & b & 1,546 \\
\hline Garden beds south and west of Cotton car park & c & 489 \\
\hline Amenity planting strips beside buildings and in courtyards & $d$ & 2,385 \\
\hline $\begin{array}{l}\text { Glasgow Street and rear of marae, Murphy and Hugh } \\
\text { MacKenzie buildings }\end{array}$ & e & 2,824 \\
\hline $\begin{array}{l}\text { Rear of Von Zedlitz and even numbered Kelburn Parade } \\
\text { houses }\end{array}$ & $f$ & 2,719 \\
\hline $\begin{array}{l}\text { Hunter Lawn and Kelburn Parade border including main } \\
\text { entrance to Hunter }\end{array}$ & g & 1,662 \\
\hline Salamanca Road Pōhutukawa forest & $\mathrm{h}$ & 3,354 \\
\hline $\begin{array}{l}\text { Either side of the Mount Street path (off-shore islands } \\
\text { collection) }\end{array}$ & j & 573 \\
\hline Waiteata Road gardens & $\mathrm{k}$ & 2,922 \\
\hline Laby border gardens & I & 1,678 \\
\hline Boyd Wilson field to the Recreation Centre & $\mathrm{m}$ & 7,888 \\
\hline Te Puni Village Hostel southern slopes & $\mathrm{n}$ & 1,086 \\
\hline Mount Street cemetery & 0 & 5,109 \\
\hline Fairlie Terrace odd numbered houses & $p$ & 999 \\
\hline
\end{tabular}

Frequency analysis

Data for each of the 15 blocks was sorted and analysed in excel using the VLOOKUP, COUNTIF and SUMIF functions. This enabled the calculation of species occurrence, frequency, and basal area, as well as sorting by tree height for each block.

Common and un-common species overall and by block were determined and indigenous species with a national threat status of At Risk or Threatened (de Lange et 
al. 2013) were identified using the Plant Conservation Network website (www.nzpcn.org.nz). Introduced species were also checked for threat status.

\section{Vegetation comparison by block}

Ordination analysis was undertaken on the densities per hectare of all species that occur in three or more blocks ( $n=83$ species). Two analyses were undertaken in R x64 3.1.3 , an open source software package for statistical computation and graphic display. The first was a principal coordinate analysis (PCO) to illustrate similarities and dissimilarities between the species composition of each block. The second was non-metric multi-dimensional scaling (NMDS) to find the relationship between the dissimilarities in the species/block matrix.

Diversity analysis

Species diversity was calculated for all of the blocks using Shannon's diversity index (Magurran 1988)

$$
H^{\prime}=-\sum_{i=1}^{R} p_{i} \ln p_{i}
$$

Where $\mathrm{H}$ is the Shannon diversity index; $\mathrm{Pi}$ is the proportion of the entire population of the block made up of species $\mathrm{i} ; \mathrm{R}$ is the number of species encountered; and $\Sigma$ is the sum from species 1 to species $\mathrm{S}$. The Shannon diversity index is commonly used to characterise species diversity in a community.

A diversity score was calculated for all of the 15 blocks and for the campus as a whole.

\section{Recruitment}

Trends for the potential future canopy of the forested areas were determined by analysing the distribution of tree species across size classes (understory, sapling, canopy) with respect to groundcover/seedling diversity

Recruitment data was analysed to determine the invasive characteristics of plants that would show whether they are, or might become, weeds. Species with a relative frequency (compared with all other species with seedlings on campus in that size 
class) of $\leq 1 \%$ in the size classes: seedlings, $2 \mathrm{~m}$ and $3 \mathrm{~m}$, were separated from the rest of the data set as these were considered to have a low rate of recruitment.

\subsubsection{Oral history research}

A number of people were approached for information on the history of the campus gardens and their use for educational purposes. These included: Andrew Jensen, current Grounds Manager, Bark Ltd (November 2013), Mike Orchard, Grounds Superintendent 1986-1996 (11 April 2015), Alan Hoverd, Technical Team Leader, School of Biological Sciences VUW (2 April 2015) Stephen Hartley Senior Lecturer Conservation Biology VUW (16 April 2015), Wayne Linklater, Associate Professor of Conservation Science VUW (27 April 2015), Rob Lucas, Greenhouse Technician, SBS VUW early to mid 1980s (30 April 2015), Emeritus Professor John Dawson, VUW (27 April 2015), Matt McGlone VUW Alumnus early 1960s (1 May 2015), Lesley Milicich, Technician, SBS VUW (13 May 2015), Emeritus Professor Phil Garnock-Jones VUW (16 March 2016). I would like to thank these people for agreeing to be interviewed.

\subsubsection{Literature search}

A literature search was conducted for relevant species lists relating to remnant and regenerating indigenous forest in the vicinity of the Victoria University campus. Comparisons were made between the plant species identified during the field study of the campus and lists for the campus from 1961-82 and from 1990 in order to determine which plants had been successful and what changes had occurred in species diversity. These historic species lists were contained in a cardboard box along with other material pertaining to the historic management of the campus grounds. The box was stored in the office of the garden maintenance contractor. All of the material from the cardboard box is now held by the Manager of Information and Records Management, Victoria University of Wellington, awaiting accession. It will then be available to anyone wishing to research the history of the campus grounds.

Comparisons were also made between the campus indigenous tree diversity and indigenous tree diversity in the forest remnants in the nearby Wellington Botanical Gardens based on records made by Buchanan (1875) and Myers (1987). And finally the campus indigenous plant diversity was compared with a plant checklist from a 
nearby reserve where restoration planting and weed control has been undertaken for the last 30 years (Wellington Botanical Society 2007)

\subsubsection{GIS campus environments analysis}

Topography of the campus forest patches was analysed in Arc GIS to determine the percentage of steep slopes. The slopes were separated into a gradient using Jenks natural breaks optimisation, a data clustering method (Jenks 1967) This was then related to the history of land use to help determine age and development of soils in blocks

\subsection{Results}

Altogether 177 tree and shrub species were identified and measured on the Kelburn campus; 112 indigenous species and 65 introduced species (Appendix 2.1). In all they represent 115 genera from 66 families, and a total of 5,967 stems. There are 816 individual introduced trees and the remainder $(5,151)$ are indigenous. Indigenous trees and shrubs from 42 families are represented by 53 genera. Introduced trees and shrubs from 34 families are represented by 60 genera.

\subsubsection{Frequency of indigenous species}

The most commonly occurring species overall was kawakawa (Piper excelsum subsp. excelsum) (Table 2.2). Nine hundred and sixty four kawakawa with a total basal area of $32.34 \mathrm{~m}^{2}$ were recorded. Pōhutukawa (Metrosideros excelsa) trees had the highest recorded total basal area (273.05) and were also in the top ten for frequency. Ten of the eleven most frequently occurring species are indigenous and seven of these eleven are bird dispersed. 
Table 2.2: List of the commonly occurring species on the campus, the ten highest total basal area measurements, and an indication of how widespread each species is across the campus.

\begin{tabular}{|c|c|c|c|}
\hline Scientific Name & Total Stems & Basal area $\left(\mathrm{m}^{2}\right)$ & $\begin{array}{l}\text { Number of } \\
\text { Blocks Where } \\
\text { Present }(T=15)\end{array}$ \\
\hline Piper excelsum subsp. excelsum* & 964 & 32.336 & 15 \\
\hline Melicytus ramiflorus* & 607 & 55.525 & 14 \\
\hline Brachyglottis repanda† & 322 & 3.887 & 9 \\
\hline Pseudopanax arboreus* & 226 & 5.627 & 9 \\
\hline Metrosideros excelsa† & 211 & 273.052 & 15 \\
\hline Cordyline australis* & 207 & 14.566 & 15 \\
\hline Ulex europeus $\neq$ & 151 & 0.465 & 2 \\
\hline Pittosporum eugenoides* & 146 & 10.752 & 13 \\
\hline Cyathea medullaris $\dagger$ & 137 & 4.788 & 12 \\
\hline Pittosporum crassifolium* & 128 & 6.174 & 7 \\
\hline Coprosma robusta* & 119 & 1.613 & 12 \\
\hline Griselinia littoralis & 119 & 57.323 & 10 \\
\hline Pittosporum tenuifolium* & 90 & 17.079 & 14 \\
\hline Camellia sp. & 79 & 13.485 & 8 \\
\hline Eucalyptus sp & 65 & 11.771 & 3 \\
\hline Olearia paniculata† & 59 & 14.551 & 10 \\
\hline
\end{tabular}

* Bird dispersed seeds, $\neq$ mechanically dispersed, $\uparrow$ wind dispersed (Thorsen et al. 2009)

Block h (beside Salamanca Road) has the highest proportion of high frequency species, followed by blocks $\mathrm{m}$ and e (Table 2.3). Blocks c, g and 1 (Cotton car park, Hunter and Laby) have a low proportion of the high frequency species. Block $\mathrm{p}$ (Fairlie Terrace west) has a very high proportion of kawakawa (42.6\%) and gorse is only present in two blocks (h, Salamanca; and m, Boyd Wilson). 
Table 2.3: List of the percent frequency of the eleven most common species by block.

\begin{tabular}{|l|l|l|l|l|l|l|l|l|l|l|l|l|l|l|l|}
\hline Species & a & b & c & d & e & $\mathbf{f}$ & $\mathbf{g}$ & $\mathbf{h}$ & $\mathbf{j}$ & $\mathbf{k}$ & $\mathbf{I}$ & $\mathbf{m}$ & $\mathbf{n}$ & $\mathbf{o}$ & $\mathbf{p}$ \\
\hline Brachyglottis repanda & & & & & 5 & 2 & & 0 & 1 & 3 & 1 & 1 & 3 & & 1 \\
\hline Coprosma robusta & & & & 0 & 2 & 1 & & 2 & 8 & 0 & & & & 1 & \\
\hline Cordyline australis & 6 & 5 & 15 & 13 & 3 & 2 & 23 & 2 & 5 & 3 & 21 & 1 & 1 & 10 & 5 \\
\hline Cyathea medullaris & 2 & 3 & & 1 & 3 & 8 & & 0 & 2 & 6 & 2 & 1 & 1 & & 9 \\
\hline Melicytus ramiflorus & 5 & 3 & 3 & 1 & 5 & 5 & 1 & 8 & 8 & 6 & & 18 & 15 & 6 & 3 \\
\hline Metrosideros excelsa & 2 & 4 & 3 & 5 & 1 & 0 & 11 & 8 & 2 & 3 & 7 & 2 & 6 & 21 & 2 \\
\hline $\begin{array}{l}\text { Piper excelsum subsp. } \\
\text { excelsum }\end{array}$ & 6 & 3 & 3 & 1 & 16 & 15 & & 28 & 11 & 22 & & 19 & & & 43 \\
\hline Pittosporum crassifolium & 1 & 0 & & & 3 & & & 8 & 4 & 2 & & 2 & & 10 & 0 \\
\hline Pittosporum eugenoides & 4 & & 3 & 4 & 2 & 8 & 1 & 1 & 2 & 2 & & 1 & 16 & 2 & 1 \\
\hline Pseudopanax arboreus & 1 & 4 & & 2 & 1 & 2 & 4 & & & 1 & & 8 & & & 1 \\
\hline Ulex europeus & & & & & & & & 4 & & & & 6 & & & \\
\hline
\end{tabular}

A large number of indigenous species are present in low numbers (Appendix 2.2). Seven species are represented by only four trees, eight species by three trees each, nine species by two trees each and sixteen by only one tree. Of particular interest are eight Threatened or At Risk species (Table 2.5). A number of common Wellington species are not present although they might be expected to have been planted or selfintroduced. The most unexpected missing species are two very common, canopy species of Wellington lowland forest; tawa (Beilschmiedia tawa) and kohekohe (Dysoxylum spectabile).

\subsubsection{Frequency of introduced species}

The most abundant introduced species is gorse (Ulex europeus). Camellia cultivars have the greatest recorded basal area and are the second most abundant introduced species (2.4). Seven of the ten most abundant introduced species are also listed as pest plants by either Wellington City Council (2014) or Greater Wellington Regional Council (2009). 
Table 2.4: List of the ten most commonly occurring introduced species on the campus, their frequency, total basal area, and an indication of how widespread each species is across the campus.

\begin{tabular}{|l|l|l|l|}
\hline Scientific Name & Total Stems & Basal area $\mathbf{( m}^{2} \mathbf{)}$ & $\begin{array}{l}\text { Number of } \\
\text { Blocks Where } \\
\text { Present }(\mathbf{T}=\mathbf{1 5})\end{array}$ \\
\hline Ulex europeus† & 151 & 0.465 & 2 \\
\hline Camellia cv & 79 & 13.485 & 8 \\
\hline Paraserianthes lophantha* & 75 & 0.214 & 5 \\
\hline Eucalyptus sp & 65 & 11.771 & 3 \\
\hline Cytisus scoparius* & 53 & 0.191 & 5 \\
\hline Acer pseudoplatanus & 38 & 8.011 & 9 \\
\hline Prunus serrulata* & 32 & 2.012 & 7 \\
\hline Ilex aquifolium* & 32 & 6.283 & 6 \\
\hline Fatsia japonica & 25 & 0.300 & 5 \\
\hline Euonymous cv* & 22 & 1.366 & 4 \\
\hline
\end{tabular}

* Listed in Our Natural Capital, Wellington City Council biodiversity strategy and action plan 2015.

† Listed in Pest plants of the Wellington region (Greater Wellington Regional Council document reference No. GW/BIO-G-09/67).

Forty one indigenous species are un common (four or fewer) including 16 which have only one. A number of these are threatened (2) or at risk (6). Forty two introduced species are present in low numbers (four or fewer). One of these, boobialla (Myoporum aff. insulare) is a ngaio from Tasmania which is known to hybridise with New Zealand ngaio (de Lange 2006). An unusual introduced species is a member of the Podocarpaceae which cannot be identified to genus and species level due to an absence of fruit. This tree is at the top entrance to the Mount Street Cemetery and is easily identified by its distinctive hammered bark.

\subsubsection{Threat status}

Seventeen of the indigenous species on campus are considered 'Threatened' or 'At Risk', with seven of these species originating from off-shore islands rather than mainland New Zealand (Table 2.5 below). These trees have all been planted. 
Table 2.5: 'Threatened' and 'At Risk' trees recorded on the Kelburn campus.

\begin{tabular}{|c|c|c|c|}
\hline Species & Threat Status & Distribution & Frequency \\
\hline $\begin{array}{l}\text { Coprosma macrocarpa } \\
\text { subsp. macrocarpa }\end{array}$ & $\begin{array}{l}\text { At Risk-Naturally } \\
\text { Uncommon }\end{array}$ & Three Kings Islands & 3 \\
\hline Coprosma virescens & At Risk-Declining & $\begin{array}{l}\text { North and South } \\
\text { Islands }\end{array}$ & 22 \\
\hline Hebe tairawhiti & $\begin{array}{l}\text { At Risk-Naturally } \\
\text { Uncommon }\end{array}$ & $\begin{array}{l}\text { North Island, East } \\
\text { Cape region }\end{array}$ & 3 \\
\hline Melicytus chathamicus & $\begin{array}{l}\text { At Risk-Naturally } \\
\text { Uncommon }\end{array}$ & Chatham Islands & 2 \\
\hline Melicytus obovatus & $\begin{array}{l}\text { At Risk-Naturally } \\
\text { Uncommon }\end{array}$ & Cook Strait, Takaka & 9 \\
\hline Meryta sinclairii & $\begin{array}{l}\text { At Risk-Naturally } \\
\text { Uncommon }\end{array}$ & Three Kings Islands & 36 \\
\hline Muehlenbeckia astonii & $\begin{array}{l}\text { Threatened-Nationally } \\
\text { Endangered }\end{array}$ & $\begin{array}{l}\text { North and South } \\
\text { Islands }\end{array}$ & 5 \\
\hline Myoporum semotum & $\begin{array}{l}\text { Threatened-Nationally } \\
\text { Vulnerable }\end{array}$ & Chatham Islands & 1 \\
\hline Olearia lineata & At Risk-Declining & South Island & 2 \\
\hline $\begin{array}{l}\text { Piper excelsum subsp. } \\
\text { psittacorum }\end{array}$ & $\begin{array}{l}\text { At Risk-Naturally } \\
\text { Uncommon }\end{array}$ & Off-shore Islands & 12 \\
\hline Pittosporum obcordatum & $\begin{array}{l}\text { Threatened-Nationally } \\
\text { Vulnerable }\end{array}$ & $\begin{array}{l}\text { North and South } \\
\text { Islands }\end{array}$ & 1 \\
\hline Planchonella costata & At Risk-Relict & $\begin{array}{l}\text { Norfolk Is., North Is. } \\
\text { and Off-shore Is. }\end{array}$ & 6 \\
\hline Pouzolzia australis & $\begin{array}{l}\text { At Risk-Naturally } \\
\text { Uncommon }\end{array}$ & $\begin{array}{l}\text { Norfolk Is., Lord } \\
\text { Howe Is. and } \\
\text { Kermadec Is. }\end{array}$ & 1 \\
\hline Pseudopanax ferox & $\begin{array}{l}\text { At Risk-Naturally } \\
\text { Uncommon }\end{array}$ & $\begin{array}{l}\text { North and South } \\
\text { Islands }\end{array}$ & 85 \\
\hline Sophora molloyi ${ }^{*}$ & $\begin{array}{l}\text { At Risk-Naturally } \\
\text { Uncommon }\end{array}$ & $\begin{array}{l}\text { North Island and } \\
\text { Cook Strait }\end{array}$ & $34(16)$ \\
\hline Streblus banksii & At Risk-Relict & $\begin{array}{l}\text { North and South } \\
\text { Islands }\end{array}$ & 8 \\
\hline Teucridium parvifolium & At Risk-Declining & New Zealand & 2 \\
\hline
\end{tabular}

* Eighteen Sophora molloyi were removed in late 2015 to make way for a new building.

Other trees of note include New Zealand mountain five-finger (Pseudopanax colensoi var. colensoi) and canelo Drimys winteri), a flowering tree from South America, in the Waiteata Block; an unusual Podocarp of unknown species from China, in the Cemetery Block; Poor Knights coprosma (Coprosma repens aff. Poor Knights), with very small leaves, in the Mount Street Walkway Block; and several interesting Australian species, Taxandria marginata, a relative of the New Zealand kānuka (Kunzea) and mānuka (Leptospermum) trees, and an unknown species or cultivar of the Correa genus. These last two can be found in the vicinity of Hunter Building along with other more familiar Australian plants (Appendix 2.3). 


\subsubsection{Classification analysis (ordination)}

Non-metric multidimensional scaling in two dimensions (NMDS2) (R package), Principal Coordinates Analysis (PCO) Gower 1966.

When the blocks in the ordination are colour coded according to their maintenance regime a clear pattern emerges (Figure 2.2). Old, large gardens where a moderate level of recruitment is allowed by the gardeners are grouped together (blue triangles). Blocks with no recruitment allowed are loosely grouped (red triangles). The two blocks around the music department ( $a$ and $b$ ), lie across the moderate and high maintenance zones (blue red triangles). Green triangles represent low maintenance blocks. 


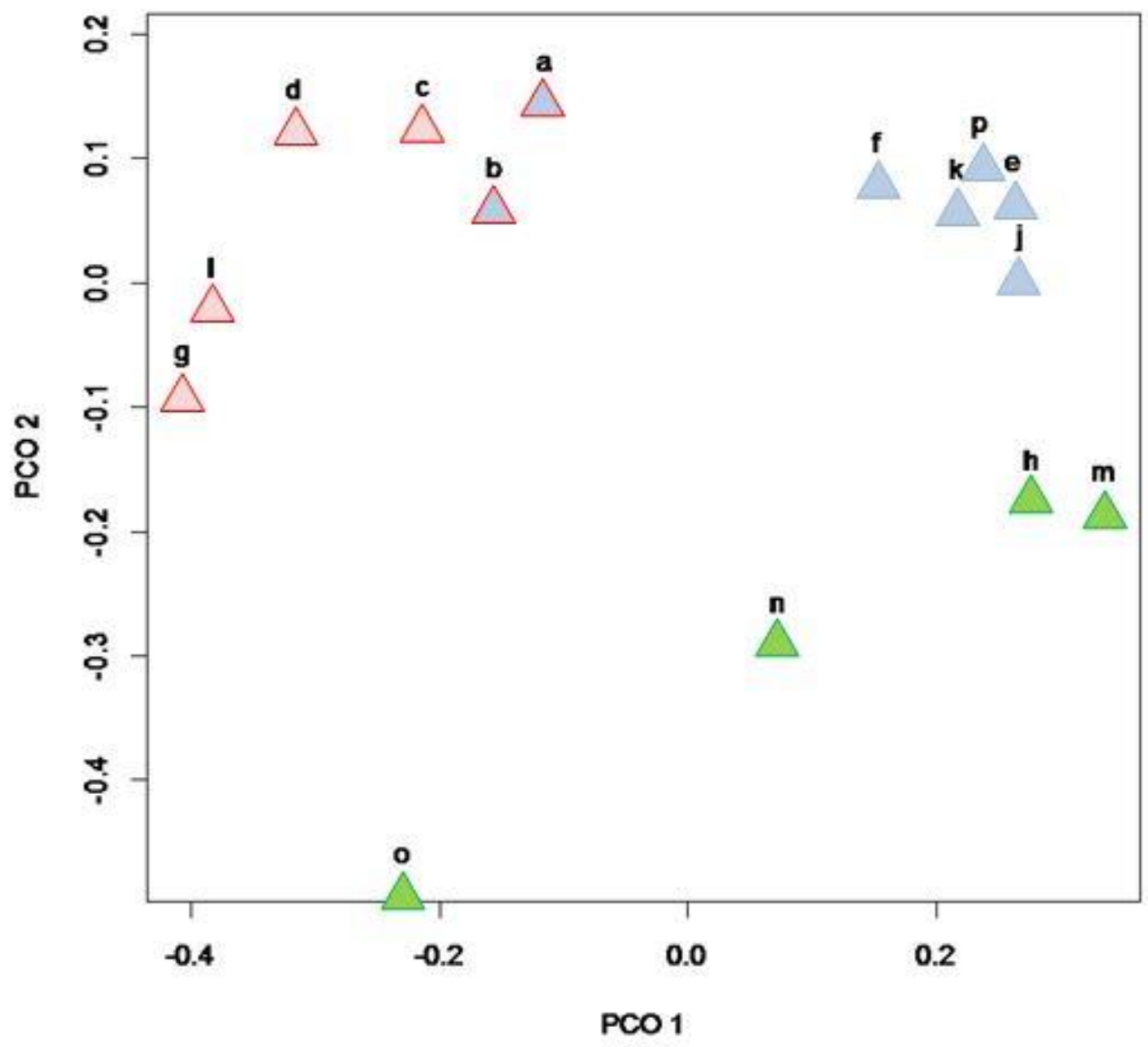

Figure 2.2: Principal Coordinates Analysis results showing clear groups: old large gardens along Waiteata Road (blue); Music Department (blue red); high maintenance, no recruitment (red); and low maintenance, high recruitment (green)

\subsubsection{Diversity}

The overall Shannon Wiener diversity index score for the campus was 3.023. The block with the highest score was Waiteata with 3.064 and the lowest score was for the Hunter lawn and gardens with 0.821 (Figure 2.3). Generally values for Shannon Wiener diversity scores should lie between 1.5 and 3.5, and in exceptional cases up to 4.5 (Kent 2011). One fifth of the vegetation blocks on campus achieved scores of less than 1.5 . 
There is no relationship between diversity index scores and block area (Figure 2.4).

However, there is a high degree of variation in tree density between vegetation blocks (Figure 2.5) and there is a slight positive relationship $r^{2}=0.3116$ between tree density and diversity index scores (Figure 2.6).

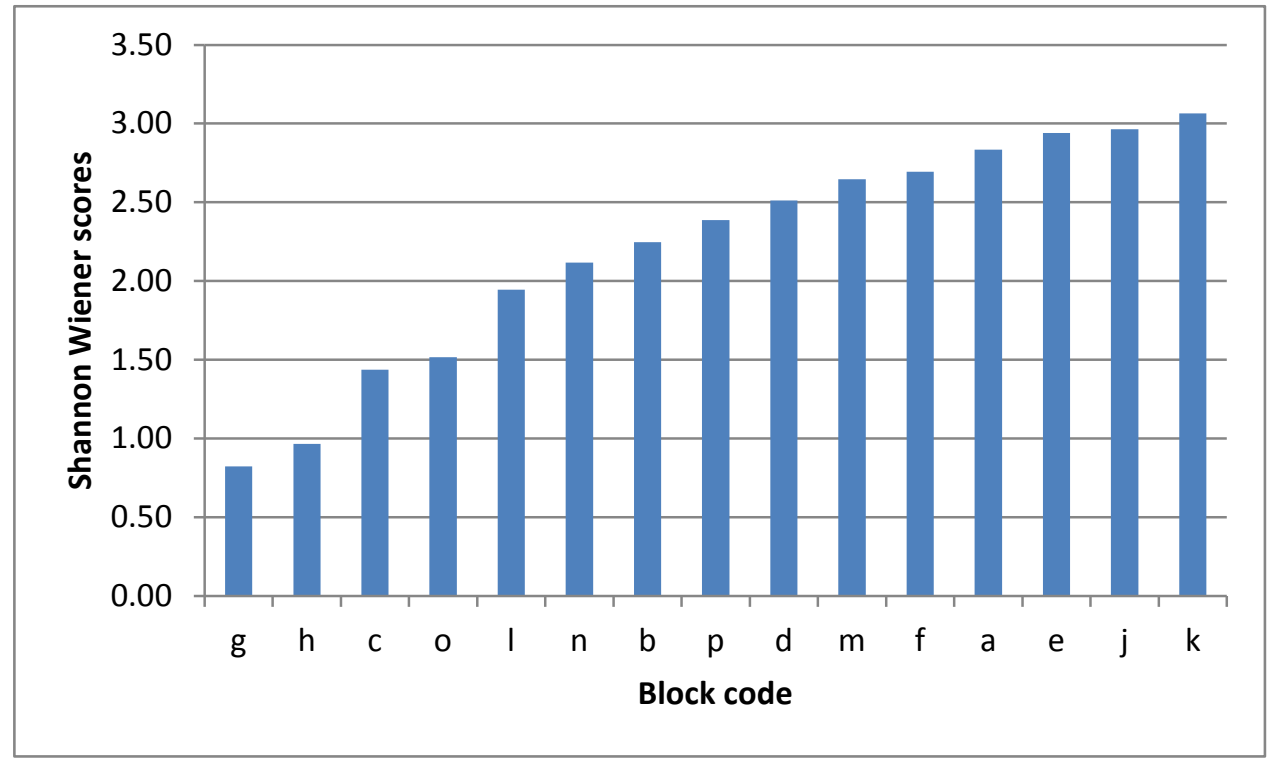

Figure 2.3: Shannon Wiener diversity index scores for each block. Although there is a score for Block $D$ this should be ignored as that block comprises 23 small separate blocks, some of which have only one tree. 


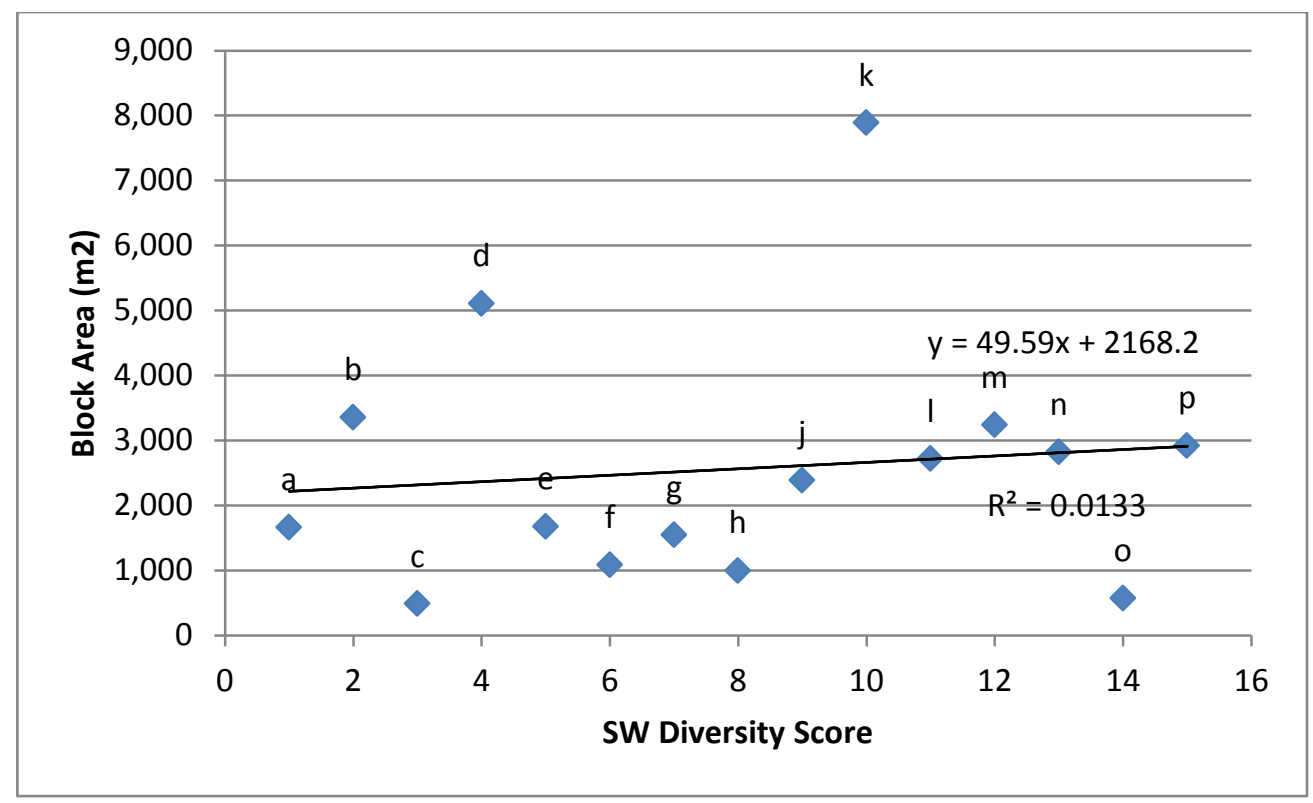

Figure 2.4: Comparison of area and score for the various vegetation blocks on campus. The $p$-value is 0.7 indicating that there is no significant relationship between diversity and block area.

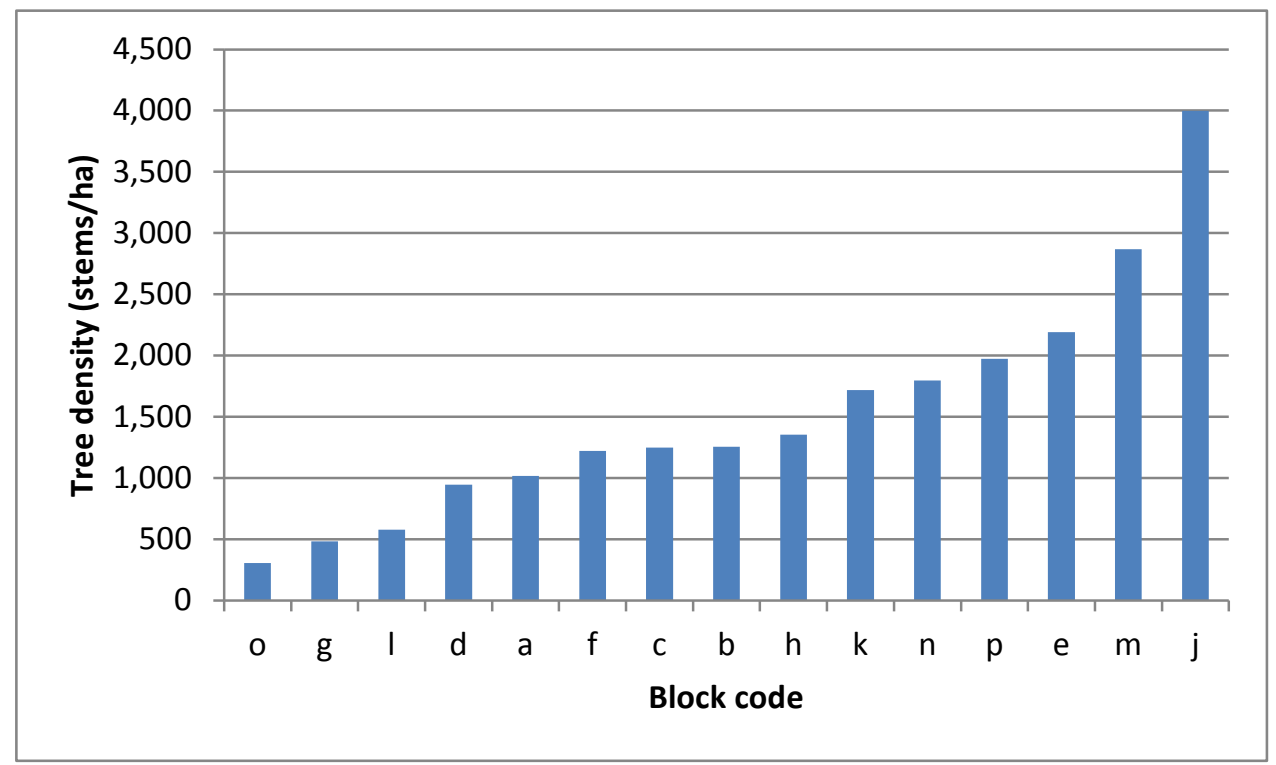

Figure 2.5: This graph shows the high level of variation in tree density between vegetation blocks. 


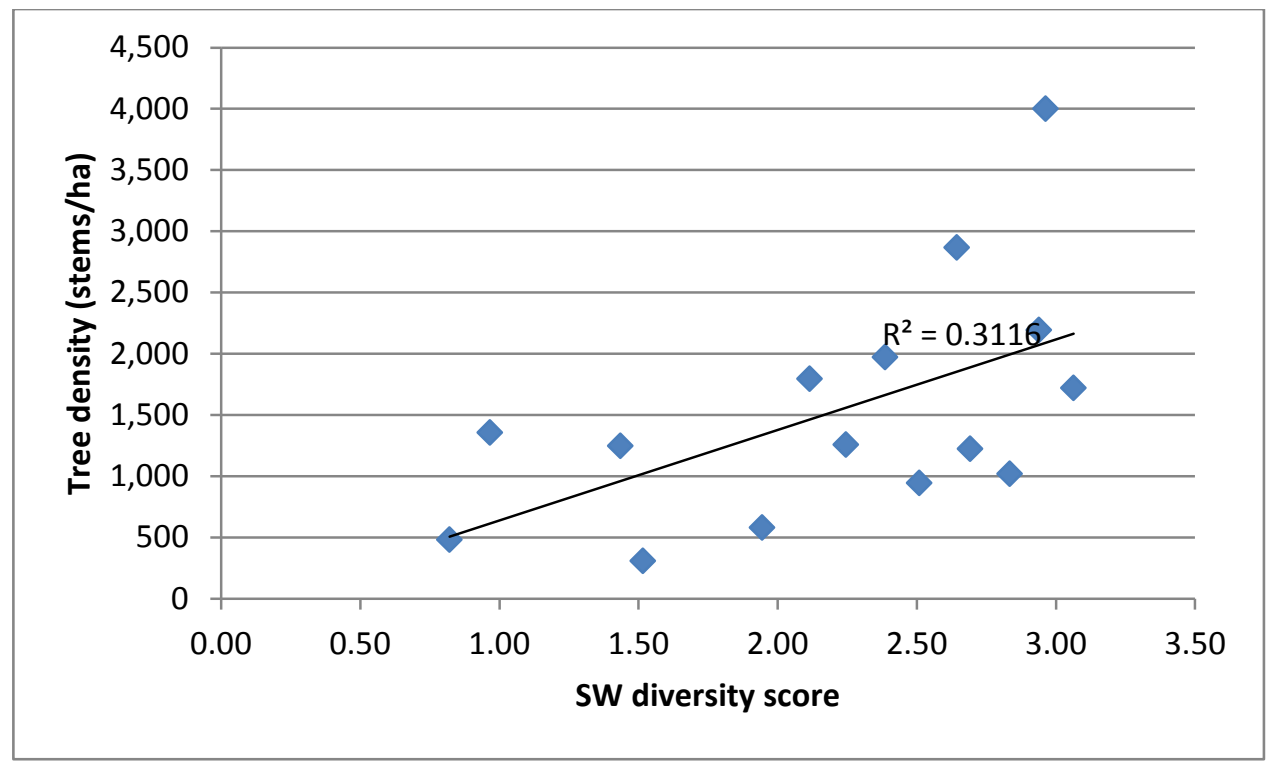

Figure 2.6: Relationship between tree density and Shannon Wiener diversity index scores. The $p$-value is 0.03 indicating a significant relationship between tree density and SW scores.

\subsubsection{Recruitment all species}

Eighty one of the 177 tree species recorded on campus had successfully seeded into the gardens (Figure 2.7 A-F). Sixty three of these are indigenous species and eighteen are introduced species. Fourteen of the recruiting indigenous species are non-local and one species reproducing freely is a hybrid between a local and a non-local species (Pseudopanax crassifolius $\mathrm{x}$ lessonii). Tree species that were not present in the canopy were not observed in the groundcover/seedling population. Kawakawa has the highest rate of recruitment with rangiora and mahoe as runners up. 


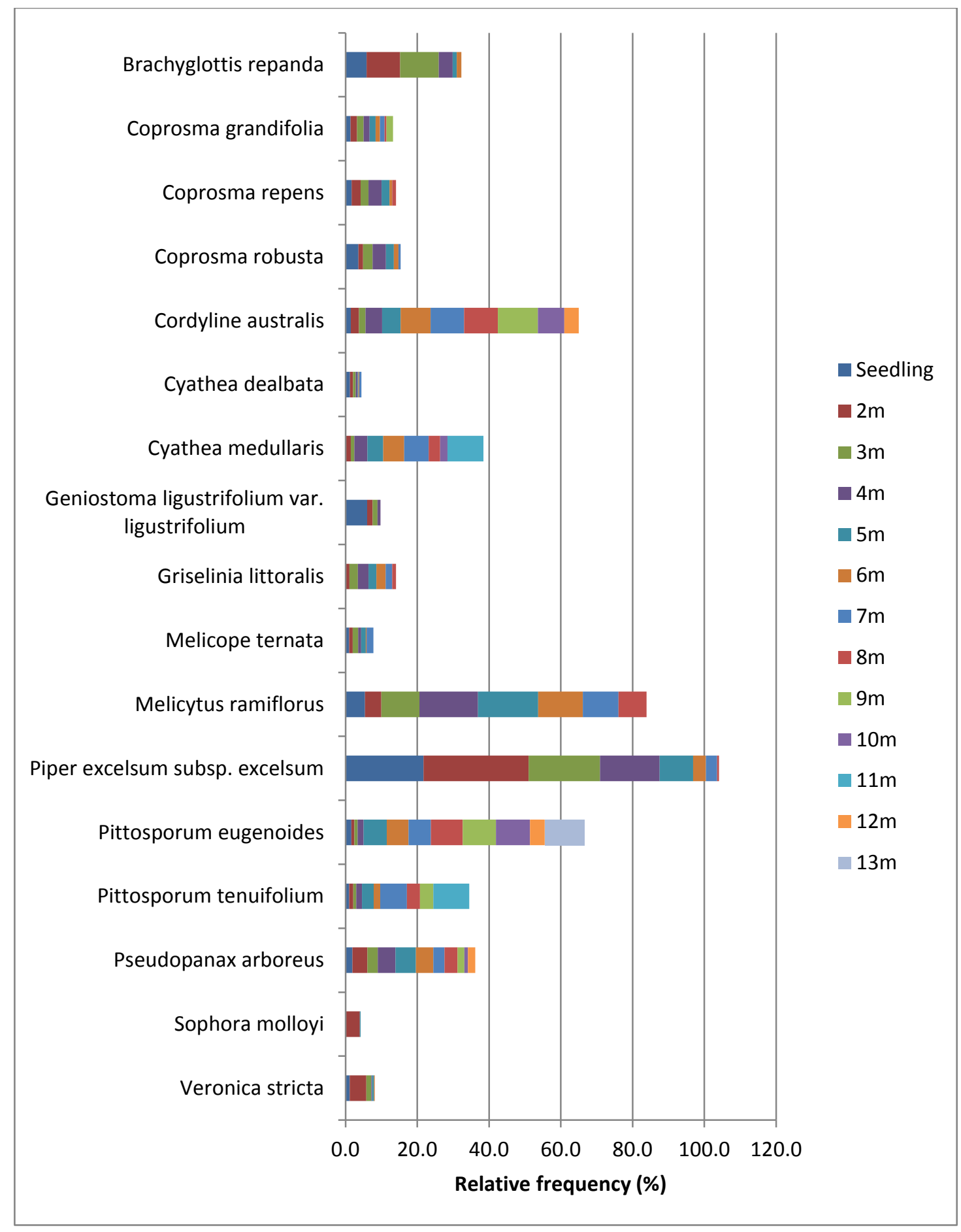

Figure 2.7A: Frequency by size class of local indigenous species (with a frequency of greater than one percent in each of the first three size classes) relative to all species with seedlings on the campus. These species are recruiting well. Sophora molloyi has a threat status 'At Risk - Naturally Uncommon'. 


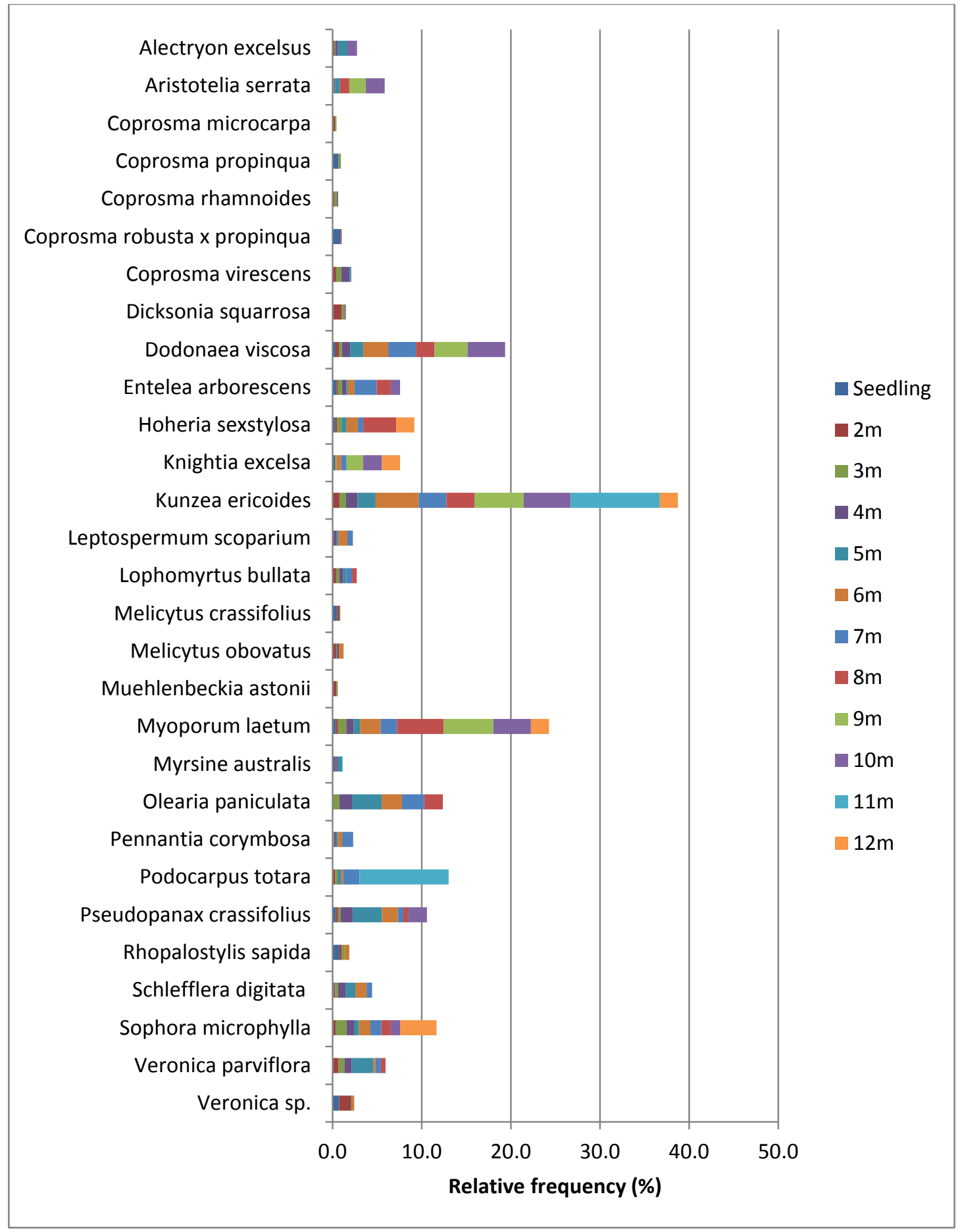

Figure 2.7B: Frequency by size class of local indigenous species (with a frequency of less than or equal to one percent in each of the first three size classes) relative to all species with seedlings on the campus. These species are not recruiting well. Coprosma virescens has a threat status 'At Risk - Declining'. Melicytus obovatus has a threat status 'At Risk - Naturally Uncommon'. Muehlenbeckia astonii has a threat status 'Threatened - Nationally Endangered'. 


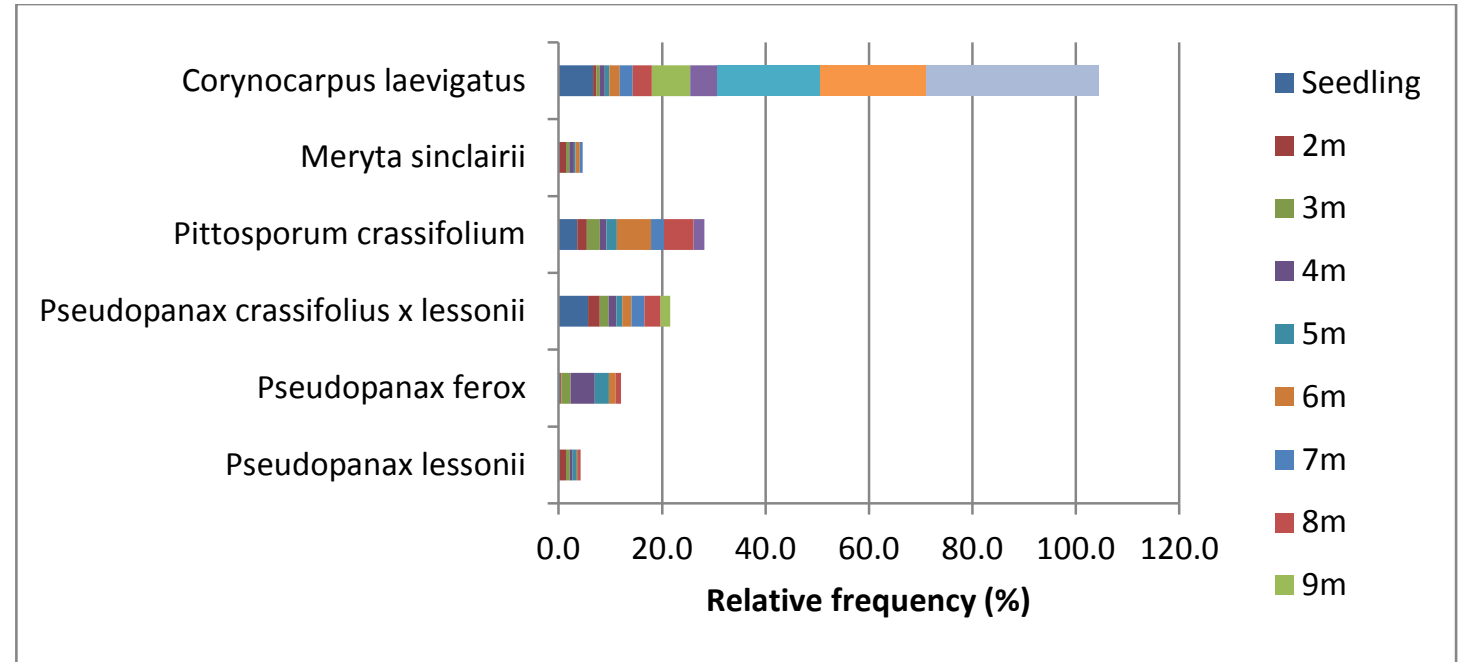

Figure 2.7C: Frequency by size class of non-local indigenous species(that have frequency of greater than one percent in each of the first three size classes) relative to all species with seedlings on the campus. This group includes a local/non-local hybrid. These species are all recruiting well. Meryta sinclairii has a threat status 'At Risk - Naturally Uncommon'.

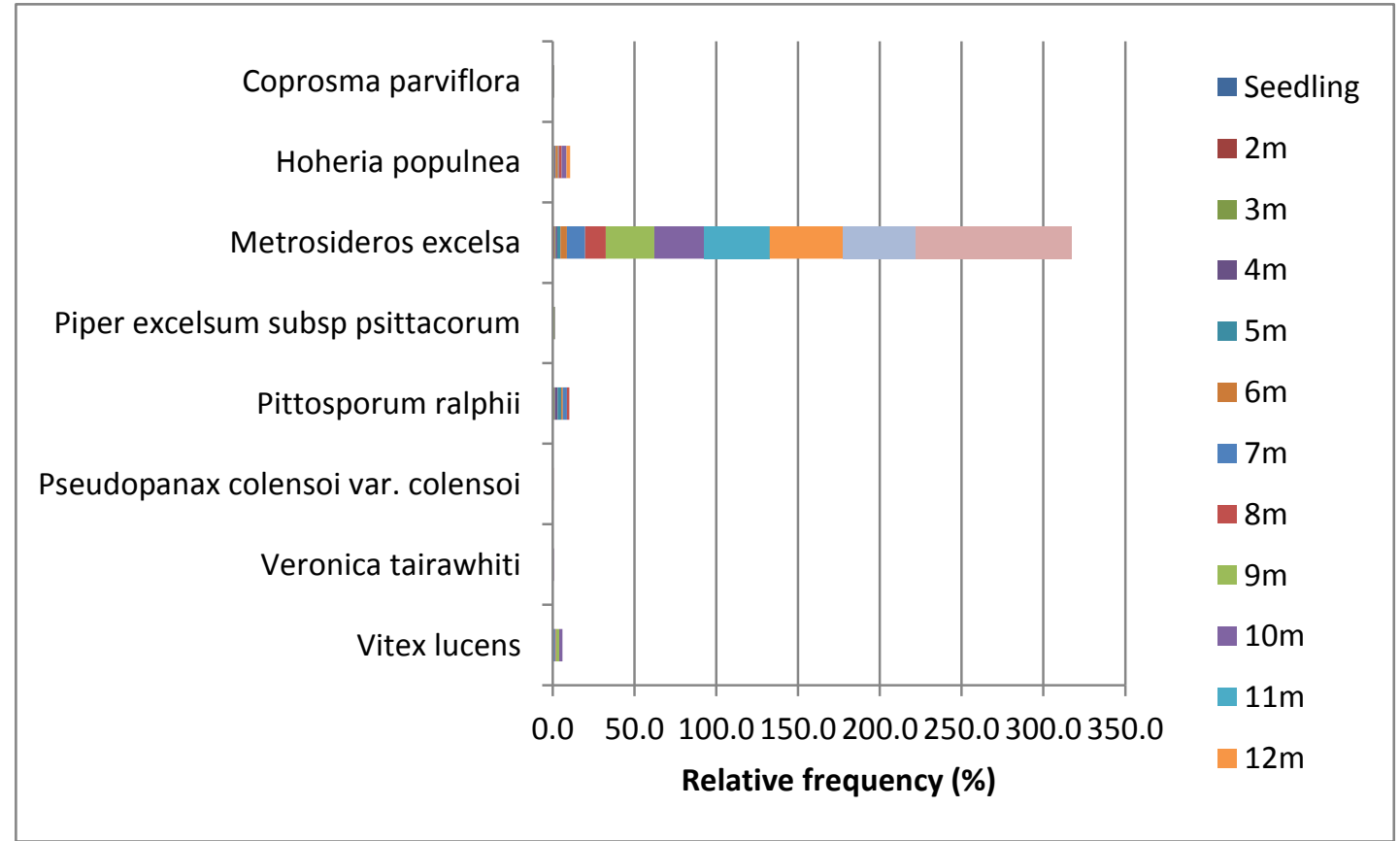

Figure 2.7D: Frequency by size class of non-local indigenous species(that have frequency of less than or equal to one percent in each of the first three size classes) relative to all species with seedlings on the campus. These species are not recruiting well. Piper excelsum subsp. psittacorum has a threat status 'At Risk - Naturally Uncommon'. 


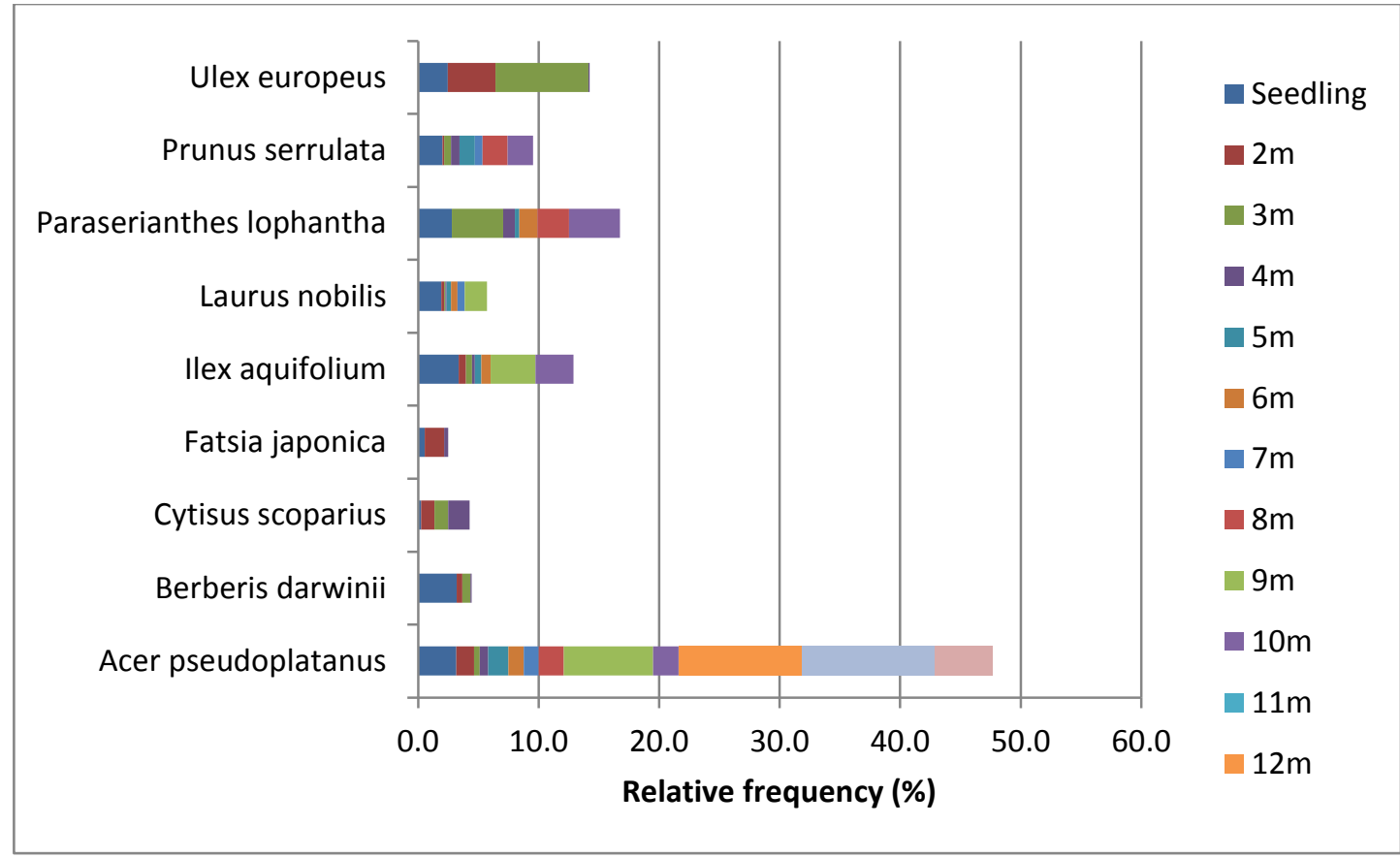

Figure 2.7E: Frequency by size class of introduced species(that have frequency of greater than one percent in each of the first three size classes) relative to all species with seedlings on the campus. These species are recruiting well.

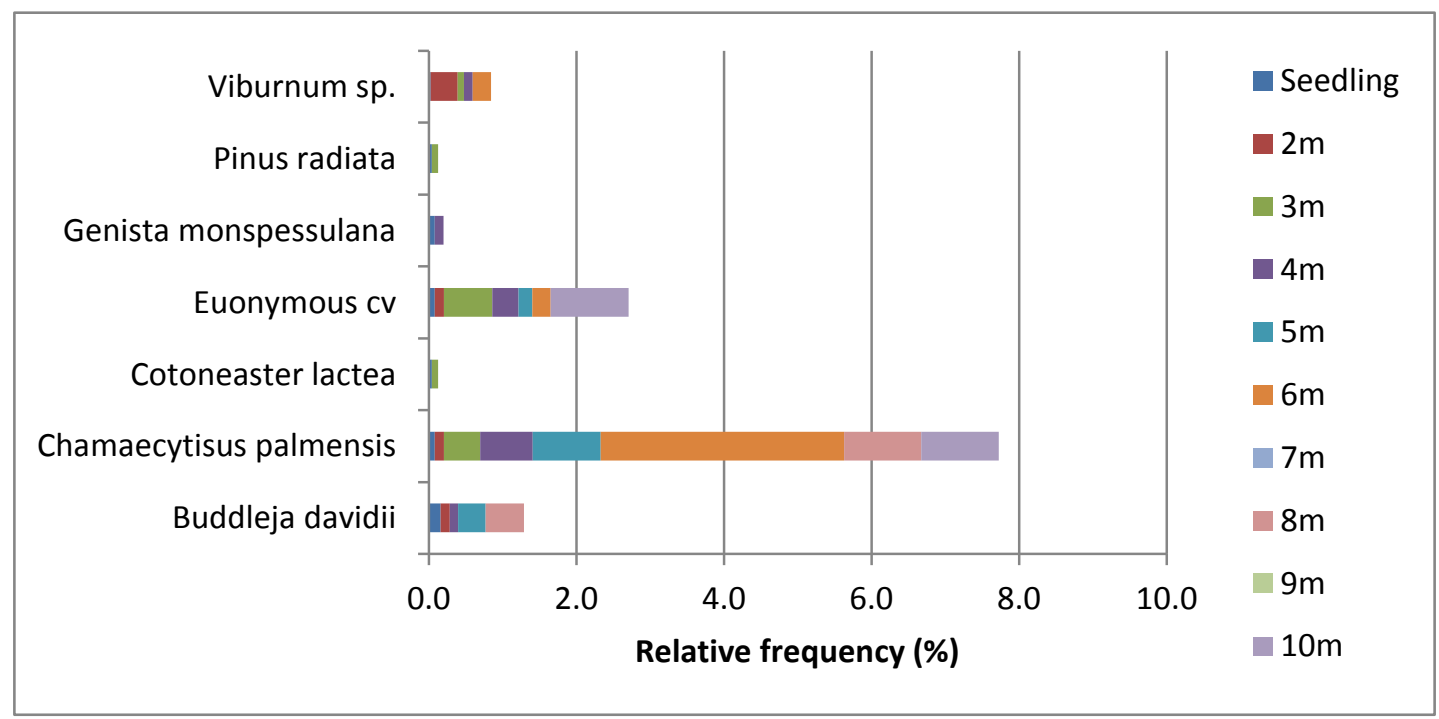

Figure 2.7F: Frequency by size class of introduced species(that have frequency of less than or equal to one percent in each of the first three size classes) relative to all species with seedlings on the campus. All but one of these species are not recruiting well. 
It is unusual that brush wattle (Paraserianthes lophantha) has a high seedling rate (144) and a moderate frequency (77) but has no saplings in the two metre range. It does have 52 saplings in the three metre size class however, and representatives in the 4,5,6, 8 and 10 m sizes.

\subsubsection{Change over time, history of campus species diversity}

Over the twenty five years between 1990 and the present day 60 indigenous species and 86 introduced species have been lost from the campus,. Lost indigenous species include Cordyline spp. (2), Carmichaelia spp. (8), Olearia spp. (9), and Veronica spp. (22).

\subsubsection{Campus garden slopes}

Three environmental factors were thought to have an effect on the success of indigenous species on the campus; slopes, soils and wind exposure. The GIS slope analysis determined that approximately $8,400 \mathrm{~m}^{2}$ of the $38,500 \mathrm{~m}^{2}$ campus gardens had a gradient of greater than 40 degrees (Figure 2.8). This equates to one fifth of the campus gardens lying on steep slopes. 


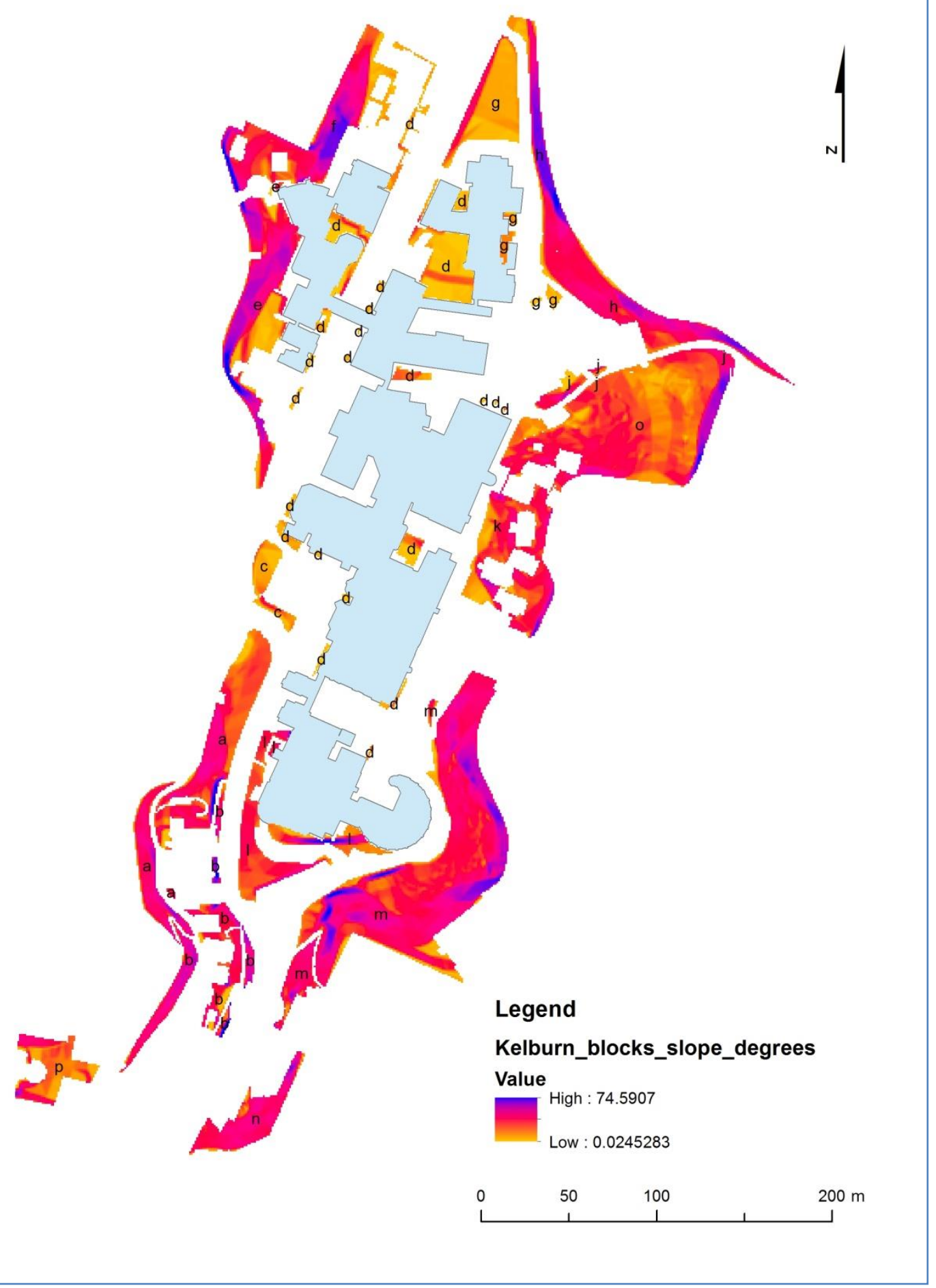

Figure 2.8: Slope angles of campus gardens. Twenty percent of campus gardens lie on slopes of forty degrees or more. The gradient data has been clustered using Jenks Natural Breaks Classification. 


\subsection{Discussion}

Any natural plant community is likely to have species that are abundant and others that are less successful. What we have on campus is a number of groups of plant communities, some of which are one hundred percent planted and others that may have up to fifty percent or more naturally recruited species in combination with planted trees. Overlying this is an uneven management regime whereby some areas are in the wilderness style, a contrived and sometimes romantic wild garden of a type that became fashionable in the mid-18th century (Leach 2000) while others are managed in a more austere institutional style of landscape gardening. The advantage of the wild garden is that it is considered to almost look after itself, with minimal intervention. Layered over this is a 21 st century ideal whereby wild gardens are expected to enhance natural capital values, in particular indigenous ecosystems (VUW no date). This has resulted in some unusual plant communities on campus.

\subsubsection{What trees do we have on campus?}

We have a long list of species ranging from those which were chosen for their ability to survive and even flourish on poor soils with high, and often salt-laden, winds. Trees were also selected for their beauty, a somewhat subjective criteria usually influenced by fashion. The pōhutukawa has always been a winner in these stakes in New Zealand and it is no surprise that it has been planted widely across the campus. Flowering trees will always be winners and this may also explain the presence of so many camellias. This plant family from eastern and southern Asia has been in cultivation in Asia for centuries and is hardy in New Zealand. It produces large and colourful flowers in winter and spring.

We have a large range of mainly indigenous species that make up the bulk of the plantings. These are dominated by fruiting species that are bird dispersed and are likely to have been planted as much to attract birds as to develop a self-sustaining base of trees for the gardens. They come from a number of families common to many New Zealand forests including Pseudopanax, Cordyline, Brachyglottis, Olearia, Cyathea, Griselinia, Geniostoma, Piper, Pittosporum, Veronica, Coprosma and Melicytus. 
The list of trees that are uncommon on the campus is a long one, and was possibly even longer during the three decades up to the mid 1990s when active planting programmes were being undertaken. During these years a strong effort was clearly being made (based on historic species lists) not only to beautify the campus grounds, but also to showcase indigenous species for educational purposes, and to enhance biodiversity values at the campus. Many introduced species that are common garden trees were planted including both conifers and broadleaved trees. Mike Orchard has mentioned (pers comm. 11/04/2015) that he deliberately sought out sites where environmental conditions might enable some of the larger indigenous trees to grow. He was unsuccessful with rimu (Dacrydium cupressinum) and mountain tōtara (Podocarpus laetus), and could only find space for one or two other gymnosperms.

\section{$\underline{\text { Frequently occurring species }}$}

In this author's experience, the species which are most abundant on campus are similarly abundant in other Wellington urban forest areas. Kawakawa, māhoe, cabbage tree, karo and karamu are at the forefront with Pittosporums other than karo not far behind This is due in part to the attractive fruits that many produce and the ability of many to recruit in the shade of a canopy of existing trees, both indigenous and introduced. These abundant species and others which are wind dispersed have not only been planted extensively on campus but many are also actively recruiting into the campus gardens (Figures $2.7 \mathrm{~A}-\mathrm{F}$ ). Where the recruiting species are local and indigenous and situated in the lower maintenance areas of the campus this is desirable and encouraged. In the 1980s and 90s mamaku were often transplanted from sites where they had self-sown to other places on campus (Mike Orchard pers comm. 11/04/2015). Utilising natural regeneration is a cost effective way to encourage the restoration of indigenous forest cover, particularly on steep sites where planting may be hazardous.

Frequently occurring introduced species include camellia and eucalyptus species, popular, evergreen trees for the larger garden. Camellia species have been widely planted across the campus particularly under the pōhutukawa trees above Salamanca Road. Eucalyptus have proven to be hardy on sites where little else would grow such as the grassy slope below Laby and across the road from the Music Department (Mike Orchard pers comm. 11/04/2015). Both of these species will die out eventually as 
they are not recruiting on campus. It is unclear whether or not there is any plan to deal with senescent introduced species that are widespread across the campus.

The other eight species in the top ten group of introduced trees are all weedy species to a greater or lesser degree. All of them feature in the illustrated guide to common weeds of New Zealand (Popay et al.) although none are listed in the National Pest Plant Accord (biosecurity.govt.nz) and only one, gorse, is listed in the Wellington Regional Pest Strategy (gw.govt.nz/pest-plants). All species except gorse and fatsia are listed by Wellington City Council as pest plants in their policy document Our Natural Capital (2015). Australian brush wattle (Paraseriantes lophantha), sycamore (Acer pseudoplatanus), flowering cherry (Prunus serrulata) and holly (Ilex aquifolium) are all moderate to large sized trees that produce a large number of fruit that is highly palatable to birds. These species are recruiting well on the campus. Gorse (Ulex europeus), broom (Cytisus scoparius), Fatsia japonica and Euonymous are smaller in stature and also recruiting.

Gorse, introduced to New Zealand as a hedge plant by European settlers, produces prolific seed that is mechanically ejected from the pod and can remain in the soil seed bank for up to sixty years (Popay et al. 2010). This species, when established, can provide a nursery crop to shelter regenerating indigenous species. It has established on campus under an area of coppiced eucalypts at the top of Block m, which runs above the Boyd Wilson Field north to the Recreation Centre. Here the gorse is seeding extensively onto very steep ground above Waiteata Road. The management regime for the area is low and comprises irregular coppicing of the eucalypts accompanied by planting, but little weed control. Evidence for this is the prevalence of other weed species at the site such as honey suckle, ivy and flowering cherry. 


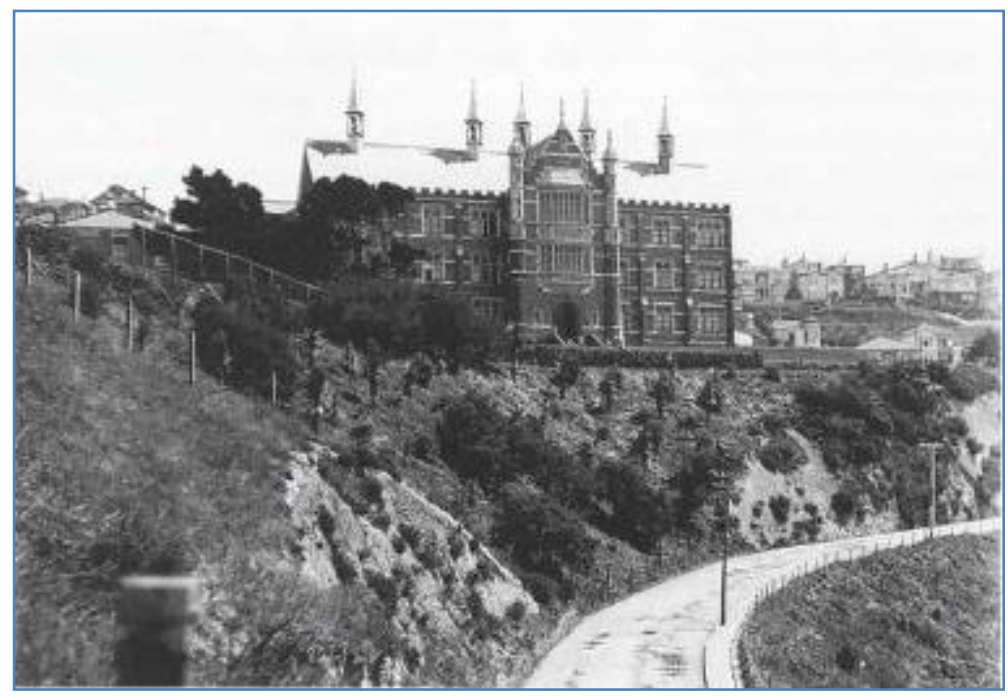

Plate 2.1: Hunter building and Salamanca Road in 1918 showing recently planted pōhutukawa trees. Adkin Collection. ATL 32178 1/4.

Two non-local indigenous species are among the most abundant species on campus. These are pōhutukawa (Metrosideros excelsa) and karo (Pittosporum crassifolium). Pōhutukawa is a hardy coastal species with a natural distribution north of a line from Taranaki in the west and Mahia Peninsula in the east. It has been planted extensively across the campus most noticeably in the dense forest alongside Salamanca Road which dates from 1918 (Plate 2.1). The large pōhutukawa on the marae behind 42 Kelburn Parade is of a similar size to the large trees in this forest and is likely to be of a similar age. This species has a low frequency of seedlings and saplings in the $2 \mathrm{~m}$ and $3 \mathrm{~m}$ cohorts and does not appear to be recruiting strongly. This is likely to be a good thing because, although pōhutukawa is regarded as an iconic New Zealand species (Simpson 2005) it has supplanted the local northern rātā (Metrosideros robusta) in the cities' forests, a circumstance that many Wellington residents deplore. 


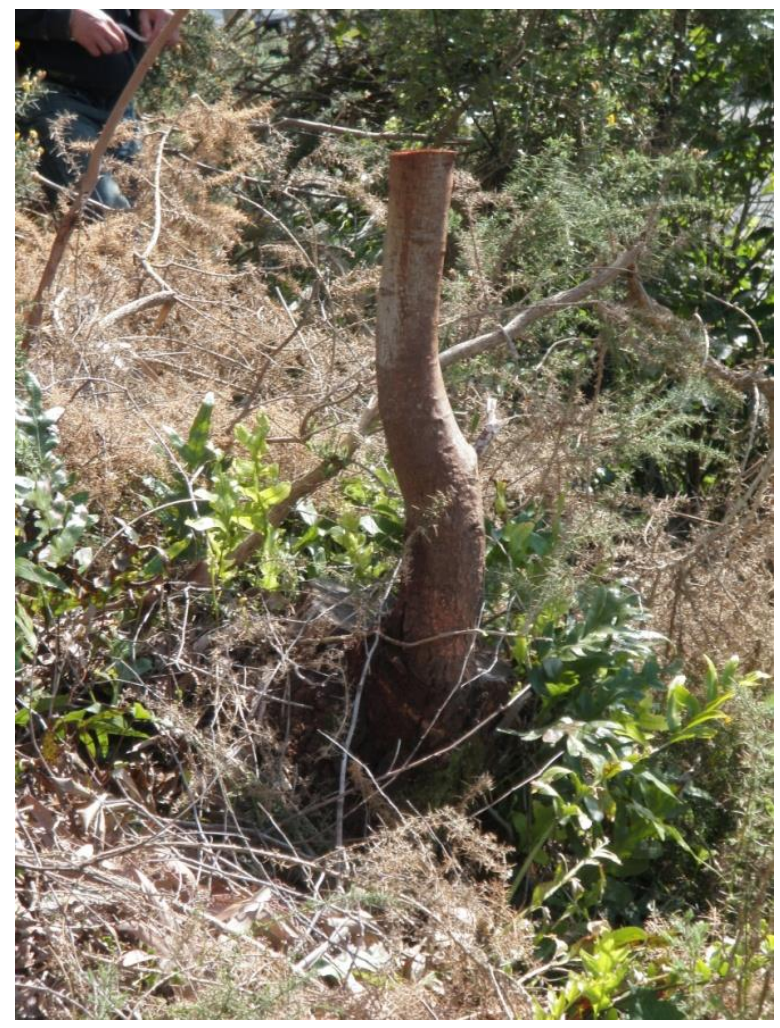

Plate 2.2: Recently coppiced eucalypt in Block $\mathrm{m}$. The surrounding gorse had been cut rather than sprayed.

The abundance of karo is of more concern. With a natural distribution in the North Island from Te Paki in the north to White Cliffs and East Cape (nzpen.org), karo is widely naturalised further south and is becoming more prevalent in Wellington's forest areas (Perrie et al. 2011). Karo has been planted so widely in the Wellington region that it is now self-propagating extensively including on Matiu-Somes Island in Wellington Harbour where a Karobusting group has been established according to the Department of Conservation website. This species has been, and continues to be, planted on campus with a group of young karo appearing recently in Block a alongside Kelburn Parade. Karo is recognised as a pest plant in the Wellington City Council Our Natural Capital policy document.

\section{Species that occur infrequently}

Many of the uncommon species; those planted in small numbers, those with a short life-span, and others that had the misfortune to look scruffy after a time due to poor management, have been lost. However, there remains a long list (82) of species with only one to four representatives on the campus. These may be relicts of once larger populations or may always have been uncommon. They may not have been planted in 
large numbers either because they were difficult to source or because of a lack of appropriate habitat to plant them into.

Most of these uncommon species are not recruiting. They may not produce viable seed due to pollen limitation, a lack of fertilisation, appropriate pollinators, because environmental conditions are unsuitable or because seedlings are weeded out. They may be planted to far apart for cross pollination to occur.

There appeared to be little interest in these rare and uncommon species amongst both the garden staff or School of Biology staff that I interviewed. However, one academic thought that the introduction of a plant identification app. for use on a mobile phone could draw more attention to these trees, some of which are very interesting from a botanical point of view, and help to protect them. However, nothing will protect them from a gardener who cannot identify and value them, or whose contract does not require this.

\subsubsection{Diversity of campus trees}

The Shannon Wiener diversity scores for the Kelburn campus were moderate to low (Kent 2011). I could find no directly comparable site to the Kelburn campus in the literature. New Zealand sites for which Shannon Wiener scores had been calculated comprised one hundred percent indigenous species. Research into the plant diversity of urban forests is a relatively recent field of study, particularly in New Zealand forests of mixed indigenous and introduced species. Many plant checklists available in the New Zealand Plant Conservation Network database do not mention introduced species, or list them separately as adventives with no indication of what proportion of the vegetation comprises introduced species. For instance a list for the native forest remnants in the Wellington Botanic Garden (Myers 1987) makes no mention of the fact that a large number of introduced species are present amongst the remnant indigenous species.

Globally urban plant diversity is being conducted and analysed using a wide variety of methods and levels of sampling effort which makes comparison difficult (Nielsen et al. 2014). According to Gentry (1988) species diversity in natural forest varies globally with distance from the poles with higher diversity scores recorded just south of the equator. Bellingham et al. (1999) also found that species diversity of New 
Zealand indigenous forest declined with increasing latitude. The 14 New Zealand forests Bellingham et al. surveyed had diversity index scores that ranged from 0.01 at Craigieburn in the Southern Alps, to 2.33 at Whitcombe in the West Coast region. Burns (2007) found that the slightly higher diversity in New Zealand forest was due to denser plant populations than in the northern hemisphere. When Burns controlled for geographic variation in plant density the diversity patterns were reversed, indicating that northern hemisphere forests have a higher tree diversity.

Jim and Liu (2001) looked at species diversity at 14 institutions in Guangzhou, 13 of which were university or college campuses; and at 21 parks and temples, and urban roadside forest. Guangzhou is known as the garden city of China and has a humid, sub-tropical climate. As with the Kelburn campus, all of Jim and Liu's study areas had an exotic species component that gave them a higher species richness score than the degraded natural forests without exotics in the nearby, surrounding countryside. Jim and Liu found that although species diversity for institutional gardens, as measured by Shannon's index, was high at 4.68, it was, nevertheless, lower than either the roadside forest areas (5.46) or the parks (5.80). The authors do not discuss how they aggregated the scores for the different areas and no standard error calculation is provided. The institutional grounds tended to have younger vegetation than the other areas as they fall into newer districts. The institutional forests had higher species richness than the other areas but may have had lower mass, measured by basal area, than the other forests which were spread more evenly across the city. Guanzhou, at 23 degrees north, is considerably closer to the equator than Wellington (41 degrees south) and urban forest there would be expected to show higher diversity than Wellington urban forest.

There have been a number of other studies of urban forest and street trees in Bangalore and Chennai, India (Sudha and Ravindranath 2000; Nagendra and Gopal 2010; Nagendra and Gopal 2011; Muthulingam and Thangavel 2012); and in Oxford, Ohio (Porter et al. 2001) which reported Shannon Wiener diversity index scores (Table 2.6). Those from the tropics reported generally low scores with the exception of the Chennai study (Muthulingam and Thangavel 2012). This was based on 100, 10 x 10 plots rather than an all tree survey as was the case in Guangzhou and at Kelburn. 
A collective diversity index score of 2.79 was calculated for Chennai, which the authors regarded as a moderate result.

Table 2.6: Shannon Wiener scores and geographical reference data for a number of sites around the world.

\begin{tabular}{|c|c|c|c|c|}
\hline Survey Site & Reference & Latitude & $\begin{array}{l}\text { Shannon } \\
\text { diversity } \\
\text { index }(\mathrm{H})\end{array}$ & $\begin{array}{l}\text { Indigenous or } \\
\text { mixed exotic }\end{array}$ \\
\hline Wellington, New Zealand & & $41^{\circ} 29^{\prime} \mathrm{S}$ & & \\
\hline Kelburn campus & & & 3.02 & mixed \\
\hline Guangzhou, China & Jim and Liu 2001 & $23^{\circ} 13^{\prime} \mathrm{N}$ & & \\
\hline 14 campuses & & & 4.68 & mixed \\
\hline Chennai, India & $\begin{array}{l}\text { Muthulingam and } \\
\text { Thangavel } 2012\end{array}$ & $13^{\circ} 08^{\prime} \mathrm{N}$ & & \\
\hline Chennai City & & & 2.79 & mixed \\
\hline Bangalore & $\begin{array}{l}\text { Sudha and } \\
\text { Ravindranath } \\
2000\end{array}$ & $12^{\circ} 99 \mathrm{~N}$ & & \\
\hline Parks & & & 1.697 & mixed \\
\hline Colleges & & & 1.475 & mixed \\
\hline Bangalore & $\begin{array}{l}\text { Nagendra and } \\
\text { Gopal } 2010\end{array}$ & $12^{\circ} 99 \mathrm{~N}$ & & \\
\hline Bangalore wide street & & & $1.1 \pm 0.08$ & mixed \\
\hline Bangalore medium street & & & $1.0 \pm 0.08$ & mixed \\
\hline Bangalore narrow street & & & $1.0 \pm 0.09$ & mixed \\
\hline Bangalore & $\begin{array}{l}\text { Nagendra and } \\
\text { Gopal } 2011\end{array}$ & $12^{\circ} 99 \mathrm{~N}$ & & \\
\hline Bangalore parks (old) & & & $1.1 \pm 0.3$ & mixed \\
\hline Bangalore parks (int.) & & & $1.1 \pm 0.7$ & mixed \\
\hline Bangalore parks (new) & & & $0.9 \pm 0.6$ & mixed \\
\hline Oxford, Ohio & Porter et al. 2001 & $39^{\circ} 51^{\prime} \mathrm{N}$ & & \\
\hline Residential & & & 2.69 & mixed \\
\hline Ohio (golf course) & & & 2.30 & mixed \\
\hline Ohio (apartments) & & & 2.19 & mixed \\
\hline Ohio (business district) & & & 2.06 & mixed \\
\hline Ohio (recreational area) & & & 1.94 & indigenous \\
\hline Ohio (preserve) & & & 1.70 & indigenous \\
\hline
\end{tabular}

Burns (2007) states that plant species diversity is difficult to characterise, particularly as area based estimates of diversity from plots can be confounded by variations in 
population density. Muthulingam and Thangavel do not describe the management regime for their plots or the levels of natural recruitment. For these reasons and also due to the proximity of the Chennai sites to the equator, the study is not directly comparable with that for the Kelburn campus.

Oxford, Ohio, at latitude $39^{\circ} 51^{\prime} \mathrm{N}$ could be roughly comparable with Kelburn $\left(41^{\circ} 29 ' \mathrm{~S}\right)$. However, the Porter et al. study does not include urban forest, instead it compares small, circular plots (0.04 ha) from large vegetation patches (100-1,400 ha) in peri-urban reserves with plots of the same size in suburban, high density residential and business district sectors. The urban plots included pavement, buildings and grass, as well as trees. Suburban areas scored highest for diversity (SW 2.69) and scores fell with increasing urbanisation (apartments 2.19; business 2.06), and with increasing 'naturalness' (golf course 2.03; recreational area 1.94; preserve 1.70).

The total tree basal area in the Ohio study was said to decrease as sites became more urban despite differing significantly among sites. The total basal area per hectare scores for the Ohio sites were several orders of magnitude lower than the Kelburn score of $2,965.9 \mathrm{~m}^{2}$ (preserve $34.8 \mathrm{~m}^{2}$; recreational area $15.1 \mathrm{~m}^{2}$; golf course $4.9 \mathrm{~m}^{2}$; suburban $4.8 \mathrm{~m}^{2}$; apartments $1.8 \mathrm{~m}^{2}$ and business district $4.6 \mathrm{~m}^{2}$ ). A total of 16 plots were sampled at each of the six sites, and every tree $>3 \mathrm{~cm}$ DBH was measured. However, Porter et al. do not discuss how each plot site was selected.

Overall, compared with the sites from the above studies the Kelburn campus appears to have moderately high diversity.

\section{$\underline{\text { Ordination analysis }}$}

It is clear from the ordination analysis that the maintenance regime is having a strong influence on species diversity by limiting recruitment through weeding and the removal of over-mature plants, or un-pruned plants that have become untidy.

\subsubsection{History of campus species frequency}

The diversity of species on the Kelburn campus has changed greatly over the years rising from 192 species in the 1961-82 era to a high of 246 species in 1990 (Table 2.7). Species frequency the fell to 177 in 2014 . Losses to 2014 were greatest for introduced species which decreased in frequency by 52\% between the 1960 s and 
2014. However, during the same time period indigenous species increased by $127 \%$ between the 1960s and 1990 only to fall by $10 \%$ between 1990 and 2014 . The period up until 1995 was a time when those working in the campus gardens were enthusiastic and proactive about planting indigenous species (Mike Orchard pers comms. 11/04/2015). The focus since the grounds maintenance was contracted out appears to have been on tidiness rather than on maintaining or enhancing the indigenous species mix.

Only twenty eight indigenous species were present on all of the species lists (Table 2.8). These represent large trees which have high amenity value and are present in low numbers, and commonly recruited species. Mike Orchard mentioned that during his time as Grounds Supervisor self-recruited mamaku were so prevalent garden staff often dug them up and transplanted them to save on plant purchase costs.

Eighteen introduced species are listed on all species lists (Table 2.9). These generally comprise amenity trees. However, some species that were commonly planted in the 1960s (e.g. sycamore, fatsia and holly) are now regarded as pest plants.

Table 2.7: Historic and current species frequency on Kelburn campus.

\begin{tabular}{|c|c|c|c|}
\hline Time Period & $\begin{array}{l}\text { Number of Indigenous } \\
\text { Species on Campus }\end{array}$ & $\begin{array}{l}\text { Number of Introduced } \\
\text { Species on Campus }\end{array}$ & Total Species \\
\hline $1961-1982$ & 55 & 137 & 192 \\
\hline 1990 & 125 & 121 & 246 \\
\hline 2014 & 112 & 65 & 177 \\
\hline
\end{tabular}


Table 2.8: Indigenous species that have been present on the campus continuously between 1961 to 2014.

\begin{tabular}{|l|l|}
\hline Indigenous Species & Common Name \\
\hline Podocarpus totara var. totara & tōtara \\
\hline Cordyline australis & tī kōuka, cabbage tree \\
\hline Rhopalostylus sapida & nīkau \\
\hline Brachyglottis repanda & rangiora \\
\hline Coprosma repens & taupata \\
\hline Coprosma repens & taupata \\
\hline Corokia buddleioides & korokio \\
\hline Corokia cotoneaster & korokio \\
\hline Dodonaea viscosa & akeake \\
\hline Entelia arborescens & whau \\
\hline Griselinia littoralis & papauma, broadleaf \\
\hline Hoheria populnea & houhere, lacebark \\
\hline Knightia excelsa & rewarewa \\
\hline Leptospermum scoparium & manuka \\
\hline Melicytus ramiflorus subsp. ramiflorus & māhoe, whiteywood \\
\hline Meryta sinclairii & pūka \\
\hline Metrosideros excelsa & pōhutukawa \\
\hline Metrosideros kermadecensis & Kermadec pōhutukawa \\
\hline Piper excelsum subsp. excelsum & kawakawa \\
\hline Pittosporum crassifolium & karo \\
\hline Pittosporum eugenioides & tarata, lemonwood \\
\hline Pittosporum ralphii & karo \\
\hline Pittosporum tenuifolium & kōhūhū \\
\hline Pseudopanax crassifolius & horoeka, lancewood \\
\hline Sophora microphylla & kōwhai \\
\hline Sophora tetraptera & large-leaved kōwhai \\
\hline Vitex lucens & pūriri \\
\hline Cyathea medullaris & mamaku \\
\hline & \\
\hline
\end{tabular}


Table 2.9: Introduced species that have been present on the campus continuously between 1961 to 2014.

\begin{tabular}{|l|l|}
\hline Introduced Species & Common Name \\
\hline $\begin{array}{l}\text { Chamaecyparis lawsoniana "Wissel's } \\
\text { saguaro" }\end{array}$ & \\
\hline Juniperus chinensis & \\
\hline Acer pseudoplatanus & sycamore \\
\hline Aucuba japonica & Japanese laurel \\
\hline Buddleja davidii & butterfly bush \\
\hline Calistemmon citrinus & bottlebrush \\
\hline Chamaecytisus palmensis & tree lucerne, tagasaste \\
\hline Chimonanthus praecox & wintersweet \\
\hline Choisya ternata & mock orange \\
\hline Euonymus japonicus & spindle tree \\
\hline Fatsia japonica & Japanese aralia \\
\hline Genista monspessulana & Montpellier broom \\
\hline Ilex aquifolium & holly \\
\hline Magnolia grandiflora & southern magnolia \\
\hline Nematolepis squamea & satinwood \\
\hline Paraserianthes lophantha & brush wattle \\
\hline Pieris japonica & lily of the valley tree \\
\hline Rhododendron spp. & \\
\hline
\end{tabular}

\subsubsection{Threat status}

'Threatened' and 'At Risk' indigenous species present on campus (Table 2.5) are of botanical interest and may be useful for education purposes. They may also be useful for propagation purposes should any of the natural populations come under greater threat. Unfortunately, as all of these specimens are planted, their presence does not confer 'Significant' status on any of the vegetation according to Wellington City Council significance criteria (Myfanwy Emeny, WCC, Urban Ecology pers comm. $1 / 08 / 2016$.

\subsubsection{Recruitment}

Although 17 indigenous species are recruiting well in campus gardens a greater number (29) are not recruiting well. There are a number of reasons why this may be. One, pollen limitation, as described by Ashman et al. (2004), two, a lack of 
pollinators and seed dispersers for example Kelly et al. (2010); three, unsuitable environmental conditions; and four, seedlings are being weeded out by gardeners.

A number of non-local indigenous species are recruiting well, and may be said to have developed naturalised populations. The most frequently occurring of these is karaka. The natural distribution of karaka is inexact, due to widespread historic planting by Māori (www.nzpcn.org). However, it is generally accepted that its distribution would have been across the north of the North Island mainly in coastal situations. This species is not on the early plant species lists for the campus despite the fact that there are a large number of large karaka trees behind the marae. It is difficult to determine the age of karaka except anecdotally as they do not have clear growth rings. Karaka is well represented in all size classes from seedlings through to mature trees $>10 \mathrm{~m}$ in height, is recruiting across the campus and could be problematic in the future if it outcompetes local species.

Karo is another non-local that has naturalised across much of Wellington City. With a similar natural distribution to karaka this tree has been widely planted in Wellington due to its hardiness in the face of salt-laden winds. The fruit are very palatable to birds and is now naturalised across the region (nzpen). With examples in all size classes this species will become more common in the wilderness areas of the campus to the detriment of local species, unless action is taken to keep its spread in check. It is clear the current garden contractors favour this species as it was recently deliberately planted on the slopes above the Music Department.

Meryta sinclairii and Pseudopanax ferox are both threatened species which are highly popular as an amenity plant and are frequently to be found in Wellington gardens. Recruitment for both species is limited. However the prevalence of $M$. sinclairii behind the marae may be cause for concern.

Pseudopanx lessonii is an Auckland plant much loved and suggested for planting by landscape architects. It is likely to be present in many neighbouring gardens. However, this species hybridises freely with the local $P$. crassifolius. This relationship featured in a blog posted by Te Papa botanist Leon Perrie (10/06/2009 http://blog.tepapa.govt.nz/2009/06/10/our-promiscuous-pseudopanax-plants/). Hybrids of these two Pseudopanax are common across the campus though not, as yet, 
as common as local $P$. crassifolius. The local species is highly valuable as it produces huge crops of fruit that sustain native birds. It was also frequently observed during the inventory stage of my research, to be targeted by kākā for its sap. the hybrid plants do not appear to carry heavy fruit crops or to be targeted for sap so a change in vegetation dominance from the local five finger to the hybrid is unlikely to be beneficial for birds.

A number of weedy introduced species are recruiting well, to the extent that it is clear that they are not being managed effectively by garden staff. It is unclear whether this is due to a lack of direction or whether it is a non-compliance issue that is not being addressed by university administrators. For example there are two very large brush wattle trees behind the Music Department which ought to have been removed some years ago and which are now scattering copious seeds in the area.. The terrain is precipitous and little groundcover weeding is undertaken there. It is being found, increasingly, that introduced trees compete not only by being highly fertile but also by altering microbial soil functionalities to their advantage (e.g. Boudiaf et al. 2013).

\subsubsection{Seed dispersal and birds}

In recent years there has been an increase in populations of larger birds such as tui (Prosthemadera novaeseelandiae) and kererū (Hemiphaga novaeseelandiae) in Wellington. These birds are capable of dispersing large fruits (Kelly et al. 2010) but may not always move them far from the source. Kererū at Wenderholme Regional Park, Auckland had an abundant supply of food year round (Bell 1996) and spent most of their time in the core habitat. Rachel Bell concluded that far dispersal of seed would have been the exception rather than the norm. Wellington Botanic Gardens produce food year round for kereru and this is also the most observed species in the gardens according to NatureWatch. I observed very few kererū while undertaking my fieldwork on Kelburn campus between February 2014 and February 2015. Campbell (2006) considered that seeds were most likely to be dispersed less than $250 \mathrm{~m}$ from the source. It may be necessary to increase the amount of food available for large seed dispersing birds on campus in order to attract these birds from the Botanic Gardens. Persuading them to bring tawa fruit with them may be more of a problem.

Another bird species which may have an influence on the tree species composition of the campus gardens in the future is the kākā (Nestor meridionalis septentrionalis). 
The kākā population in Wellington has grown remarkably fast since the species was reintroduced in 2002 (Miskelly et al. 2005). Contrary to recent research (Charles 2013) which found that large, exposed, exotic conifers were the most likely trees to be targeted for bark damage/sap feeding, I observed many more five-finger trees (Pseudopanax aboreus) on the campus with damage than any other species. Almost all of the damaged trees that I observed were in out of the way spots. Although five finger ranks fourth for frequency on the campus, the species has a relatively low basal area $\left(5.63 \mathrm{~m}^{2}\right)$ indicating that many trees are as yet quite small. It is a valuable food tree for birds and may need to be planted more frequently on the campus.

\subsubsection{Environmental conditions}

One of the reasons for there being a disparity in the occurrence of local species on campus is likely to be due to a lack of suitable habitat for planting/recruiting into. As explained in my introduction, due to the process of ground levelling for the construction of campus buildings there was little soil remaining for the development of gardens. Areas that experienced the least soil disturbance were often on steep slopes where soil horizons were naturally shallow such as below Glasgow Street and on the Kelburn Parade slopes around the Music Department; or in the gardens of residential properties in Waiteata Road and at the beginning of Kelburn Parade, that have been incorporated into the campus.

Due to the difficult environmental conditions some species have been planted and not survived for example Metrosideros bartlettii (pers comm Mike Orchard).

\subsubsection{What might have been, Botanical Gardens forest remnants}

The selection of indigenous plants on campus is similar to that listed on checklists of two surveys of the primary forest remnants at the nearby (half a kilometre) Wellington Botanic Gardens (Buchanan 1875; Myers 1987. These lists (Appendix 2.4) are very similar to the current indigenous species list for Kelburn campus with some exceptions. Species that are not present in the campus gardens are: rimu (Dacrydium cupressinum), tawa (Beilschmiedia tawa), karamū (Coprosma lucida), kohekohe (Dysoxylum spectabile), kōtukutuku (Fuchsia excorticata), pukatea (Laurelia novae-zelandiae), mingimingi (Leucopogon fasciatus), horopito (Pseudowintera axillaris) and raukawa (Raukawa edgerleyi). There are also a number 
of species from outside the Wellington area on the campus that are not present in the remnant forest of the Botanic Gardens. These are planted species of amenity value, and often are also threatened species for example Meryta sinclairii.

The absence of tawa, kohekohe, kōtukutuku and Coprosma lucida is difficult to explain. None of these species appears to have been planted historically and none are present in the seedling population despite the Botanic Garden trees being less than one kilometre distant. There is always the possibility that any seedlings arising have been weeded out.

\subsubsection{What could be, Waimapihi Reserve restoration}

The 2007 checklist for Waimapihi Reserve, Aro Valley (one and a half kilometres distant from the campus) includes seven indigenous species that are not present in the campus gardens (Appendix 2.5). These are: rimu, Carmichaelia australis, Coprosma areolata, kohekohe, kōtukutuku and red beech. Fifty four species listed as present in the campus gardens are not recorded at Waimapihi Reserve. The vast majority of these are non-local species or hybrids. The one species of note missing from Waimapihi Reserve but present on campus is pigeonwood.

\subsection{Summary}

A complete inventory of trees on the Kelburn campus of Victoria University of Wellington has been made. A total of 177 tree and shrub species were identified and measured on the Kelburn campus; including 112 indigenous species and 65 introduced species. Species diversity on the campus was found to be moderate (Shannon Wiener 3.023). Species richness had diminished according to a comparison with historic records, this has affected introduced species more than indigenous ones. Some species that were expected to be present due their popularity as amenity specimens and their proximity in nearby gardens were not found. In particular tāwa (Beilschmedia tawa). The weediness of a number of introduced and non-local indigenous trees is problematic and is not being addressed by the garden management contractor. Unless this issue is addressed the future trajectory for the composition of wilderness areas on campus to resilient, self-supporting indigenous forest will be compromised. 


\section{CHAPTER THREE: PERCEIVED VALUES OF CAMPUS GREEN SPACE}

\subsection{Introduction}

\subsubsection{The values of institutional urban green space}

Trees and green spaces can ameliorate many of the problems of modern city life. Spending time in a park, living in a leafy suburb or even moving to one has proven health benefits (Alcock et al. 2014, Berto 2005, Home et al. 2012, Kaplan 1995, Kardan et al. 2015; Mitchell and Popham 2008, Tzoulas et al. 2007, Zhou and Rana 2012). Leafy campuses can also boost student performance (Wu et al. 2014) and worker well-being (Kaplan 1993), while views of, and walking in, green space can help you think better (Oppezzo and Schwartz 2014). American landscape architect Frederick Law Olmsted wrote in 1865 that being in a natural setting "gives the effect of refreshing rest and reinvigoration to the whole system" (cited in Ulrich et al. 1991).

So, urban green space makes us feel good, and is good for our mental and physical health. But what is it about green space that people like and value? A University College London Policy Briefing paper (Orr et al. 2014) summarises some of the challenges related to valuing urban green spaces. They write about the difficulty of measuring who uses such spaces, when and why; and the difficulty of measuring the ecosystem services provided by the green spaces and their monetary value.

While technology is proving useful to address these challenges, budget constraints are putting the maintenance and protection of such places under pressure. But as populations grow, so do demands on green space. Not only is more money required to maintain green space, there are strong temptations to develop urban green space. Local examples of this include Wellington City Council's suggestion to sell an inner city park (Jack Ilott Green) to developers, and Victoria University's expansion of its Kelburn campus with subsequent loss of green space for the development of the Victoria University Gateway Project.

What Orr and his colleagues (2014) do not say is that compared with those trained to identify and appreciate urban biodiversity, everyday users of urban green spaces in western countries tend to have a poor understanding of the ecosystem services that 
such spaces provide (Muratet et al. 2015). Notwithstanding this, residents in cities with high levels of pollution may be more aware of the ecosystem services provided by urban green spaces (Jim and Chen 2006). This mixed understanding of, or appreciation for green spaces presents a problem for scientists and policymakers who wish to obtain funding for the maintenance and protection of urban green space.

Many New Zealand tertiary institutions have large landscaped campuses. In fact gardens on campus were the norm until the 1990s when universities began to establish inner city campuses on scarce and expensive land, using existing buildings that were not purpose built for teaching. Victoria University, for example, now has a number of campuses in the Wellington Central Business District: the School of Architecture and Design was established in the Vivian Street in 1992; the Law School moved to the old Government Buildings on Lambton Quay in 1996; and in 1999 the university purchased Rutherford House across the road from the Government Buildings and had it refurbished for the Commerce School. The School of Architecture has no gardens but benefits from being immediately adjacent to Wellington City Council's Cobblestone Park while the other two schools at the Pipitea campus benefit from the Government Building gardens and Parliament grounds.

An example of a fairly typical New Zealand university campus is the Unitech Institute of Technology in Mt Albert, Auckland. Its campus trees form an arboretum which is used for education purposes and has a dedicated page on the institution's website. The Unitech campus reaches across 55 ha and has a tree inventory listing over 2,000 trees with more than 200 species. Landscape Architecture staff and students are actively involved in developing the arboretum and information about its trees can be accessed via online maps and phone apps. The arboretum project is funded by the Unitech Sustainability Fund. Massey University's Palmerston North campus also has an arboretum page under development and hosted by Botanic Gardens Conservation International. It also has a page dedicated to the campus grounds on the university website.

\subsubsection{Historical values attached to VUW campus}

In 1979 the Victoria University Council commissioned a review of its building and site programme. Submissions to this review were severely critical of the university's approach to planning (Barrowman 1999). There was, according to submitters, no 
integrated vision for the campus. As Barrowman observed, this was a criticism that had already been made by the Students Association in 1949. Specifically, submitters were critical of the failure of planners to consider pedestrians, microclimates and aesthetics. The promise made in 1962 by George Culliford, Assistant to the Chancellor, that in the future the university would avoid a haphazard 'conglomeration of buildings' had been an empty one. Culliford retired in 1977, although whether this opened the way for a planning review is unclear.

In 1982 Helen Tippet, Professor of Architecture at Victoria University, described the VUW campus as 'the worst campus in the developed world' (Barrowman 1999). The university and their planning consultants needed to recognise the wind tunnel effects of campus buildings and the regrettable tendency to use spaces between buildings for car parking. The university management had not managed to achieve its goal, stated by Culliford 20 years earlier, to form an organic, functional whole.

Barrowman also describes a school of thought among administrators that a university is comprised of minds rather than a place; the idea being that pragmatism and utilitarianism should guide planning. However, the appointment of a campus planning group in 1985 re-introduced the sense of place that had helped shape the earlier campuses. The first building project under this team, the Music School, included a strong landscape component with extensive planting. The Laby building, completed in 1984, was enhanced by the creation of an alpine/rock garden along the western side of the building. A lawn was laid to the south of Laby with plantings of Eucalyptus trees, the only plants that would grow there apart from pōhutukawa (Mike Orchard, pers comm. 11/04/2015). Unfortunately, the lawn is precipitously steep and being south facing is rarely used for rest or recreation. Furthermore, the lawn is not overlooked by the Music School which faces instead into a courtyard. The planting choice was, yet again, a pragmatic solution to the problem of exposed rock and clay where little else would grow.

The decade from 1986-1996 was an era when grounds staff had a strong background in botany and amenity horticulture and a particular interest in indigenous plants. There were also links between grounds staff and the academics of the School of Biological Sciences, with a number of grounds staff completing post-graduate and undergraduate qualifications in botany and ecology. Just over a decade earlier, Rob 
Lucas had been appointed to manage the greenhouses established on the roof of New Kirk in 1973 (Rob Lucas pers comm. 30 April 2015). A horticultural specialist rather than an academic, Lucas also had strong links with the native plant collections. Lucas left Victoria University in the early 1980s to take up an teaching position at the Open Polytechnic but remembers that Victoria University academics at the time took an interest in the native plant collections that were being developed around the campus by Grounds Superintendent Rob Short. During his time at Victoria, Lucas had been able to develop an extensive portfolio of photographs of native plants many of which were shot on the campus. These were used in the many books he later published with Professor John Dawson of Victoria University.

Sadly, the landscape/gardening gains of the seventies and eighties were short-lived. The development of the Alan MacDiarmid building saw the loss of a large part of the alpine collection. In the early 1990s grounds maintenance was contracted out and from this point on plants from collections were not replaced when they died. Areas of unusual native plants were removed from around buildings in Waiteata Road, apparently in order to tidy the gardens (Stephen Marshall pers comm. 2/04/2015). This outcome may have resulted from poorly trained garden staff and managers, budget constraints, contract omissions, or a combination of all of these factors.

The recent (2013) development of the Hub and the Tim Beaglehole Courtyard resulted in the loss of native brooms, some interesting small leaved shrubs along with pōhutukawa trees. New plantings in the courtyard add little to the botanical diversity of campus plantings because they comprise only a few species most of which are already in common use across the campus (Griselinia littoralis, Arthropodium cirratum, and Asplenium bulbiferum). Several Lord Howe Island palms planted in the courtyard (Howea forsteriana) are commonly mistaken for nīkau (Rhopalostylis sapida) by both university staff and students.

In the summer of 2014-15 excavations were undertaken between Kelburn Parade and Cotton, Alan MacDiarmid and Laby buildings for the foundations of a new building, known as the Gateway Project, to house the School of Biological Sciences. The excavation resulted in the loss of approximately $2,000 \mathrm{~m}^{2}$ of well established gardens with approximately 400 trees. Before their destruction, these gardens were assessed as part of the quantitative survey reported in Chapter 2. The trees included 53 species 
with an average height of $4.7 \mathrm{~m}$ (stddev 2.25), and a total basal area of approximately $700 \mathrm{~m}^{2}$. Most of the trees were more than 30 years old. Also lost were sloping lawns that were utilised by students, the last of the alpine plant collection, and the only southern rata (Metrosideros umbellata) on the campus. Under the Growing Graduates Scheme (begun in 2013), Victoria University is planting 2,000 native trees a year for five years. Nevertheless, it will be some decades before these trees can be said to mitigate the Gateway losses.

Victoria University has ambitious plans to grow in both size and influence over the next twenty years (VUW web post 1 July 2015). With many valuable plants and green spaces already lost or compromised, and opportunities for extending the green spaces somewhat constrained, it is timely that we take stock not only of what is present on the campus in the way of trees but also what values the people currently working and studying on the campus give to campus green space.

\subsubsection{Social research objectives}

The purpose of this study is to determine the value the university community places on campus green space. Understanding the views and priorities of the campus community is important if the mistakes of the past are to be avoided, and if the campus green space is going to usefully provide for the needs of staff and students into the future. I wanted to know where staff and students liked to spend their nonacademic or work time on campus, and how far they were prepared to travel from their usual work place to get there. I was also interested to know what the significant influences on people's use of campus green space were, and if gender made any difference to their choices. Finally, I wanted to know whether the current campus green space meets staff and student expectations.

\subsection{Methods}

\subsubsection{Introduction}

The objective of my survey is to determine the value that the university community places on the Kelburn campus green space by asking questions about where they go and why, and what they like about it. I undertook two surveys. The first, an elicitation survey, was a series of short, face to face interviews to determine what questions to include in the main survey, and the form that the main survey should 
take. The second, an email survey, was designed to determine campus values in greater detail, and from a larger proportion of the university community.

\subsubsection{Elicitation survey}

The elicitation survey involved face to face interviews with 27 members of staff who held academic and non-academic positions in various faculties at VUW. I used open ended questions so that respondents volunteered information about their values and their relationship with campus green space. Elicitation is a way of collecting information from people that is not readily available from any other source, for a specific purpose (Cooke 1994).

I was interested to find out people's perception of green space and the campus green space in particular, and also how much understanding they had of the role of urban green space as an ecosystem that provides benefits to the living things, including humans, that live within that system.

Interview survey questions were developed and submitted to the VUW Human Ethics Committee for approval, which was granted on 13 March 2015 (Approval No. 21538, Appendix 3.1).

One hundred and forty five university staff were selected at random to be contacted by email with a request for an interview. Staff were selected from the VUW website by generating random pairs of letters for first name and last name from a set of letters in a board game in combination with a random number selection application (www.random.org) for choosing the first, second, third, etc. person with that initial combination. Determining how many people to interview came down to how long it took the Ethics Committee to approve my study; how much time I had available to contact and confirm participants, and how many days were available to interview participants.

Baker and Edwards, in their 2014 research paper on sample size for qualitative interviews, had a number of different answers to the question of sample size including: one interview may be enough if it is sufficiently detailed; between 20 and 60 interviewees with a mean of 30; 20 for an MA thesis and 50 for a $\mathrm{PhD}$; and also, keep asking until there are no new answers. Adler and Adler (in Baker and Edwards, 
2014) point out that qualitative researchers place less reliance on numbers than researchers using quantitative methods, and often question fewer people than quantitative researchers, but in greater depth. When interviewing someone, as opposed to seeking a response to a written questionnaire, the interviewer has some leeway to delve deeper into a subject. Such 'delving' can help to frame the questions in any subsequent survey.

Emails were sent to the 145 university staff in March 2015 (Appendix 3.2) requesting recipients to volunteer for an interview. Records of responses and non-responses were kept. Non-respondents were contacted a second time and a second non-response was counted as a refusal to participate. Respondents to the first and second rounds of emails were contacted again by email to arrange an interview time and place. Interviews were undertaken with 28 respondents between 17 March and 13 May 2015.

Respondents were interviewed at a place and time of their choice and interview duration was approximately half an hour. Each person participating in the survey completed and signed a permission form (Appendix 3.3). They were asked five questions about campus green space:

- What did they understand the phrase campus green space to mean?

- Whereabouts in campus green space did they go?

- What did they use campus green space for?

- What was important to them about campus green space? And,

- Did they have anything else to say about campus green space?

I asked broad questions and allowed the participants to answer in their own words. Occasionally, especially when conversation stalled, participants were shown a map of the campus (Kelburn Campus Map 2015) or asked further questions such as which route do you take when you come and go from the campus, and what can you see from your office window? Participants were also asked demographic questions (gender, age and role at the university (Appendix 3.4)).

Interviews were transcribed and analysis followed the six-step process for thematic analysis as described by Braun and Clarke (2006). The steps were: 
1. Familiarisation with the data

2. Generating initial descriptor phrases

3. Searching for themes

4. Reviewing the themes

5. Defining and naming themes

6. Analysis of the results

\subsubsection{Methods: online surveys of staff and students}

\section{$\underline{\text { Survey design and deployment }}$}

Two online surveys were designed, one each for staff and students (Appendix 3.5). The difference recognised that students did not usually have an office or permanent workspace. In all other respects the surveys were identical. All participants were asked for their favourite and second favourite outdoor places to go. These questions were based on the results of the elicitation survey that appeared to infer that green space was an accessible place, either as somewhere to observe, or somewhere to walk past or through.

Once the survey questions had been finalised they were submitted to the VUW Human Ethics Committee (Approval No. 22271 dated 27/8/2015), (Appendix 3.6).

Participants were asked if they wanted more or less of 14 specific green space matters, including biodiversity, comfort, personal security, information and management. Specific choices were offered because the elicitation survey showed that, without prompting, few people were able to describe aspects of green space in a manner that would provide useful information to guide future management plans.

KoBo Toolbox (kobotoolbox.org) open source software was used for the survey because it has a mapping component that allows the collection of geographic point data which can then be imported into ArcGIS. This meant that survey participants could show where on the campus they liked to go and, in the case of staff, where their office was located. Having the mapping functionality meant that I was able to find out more about the distance people travel to their favourite places and allowed participants to nominate more than one favourite place. 
There was no question about the cultural background of people in the campus community and whether or not that influences the way people use campus green space. While this would have been a very interesting question to explore given that there are many students and staff from overseas using the campus, it would have lengthened the survey and I wanted to limit the time taken to complete the survey to ten minutes.

An article was placed in the University's weekly online newsletter inviting staff to participate (Vic News 14/09/2015). Students were contacted via posters with tear off tabs which were posted later that same week (Appendix 3.7), and via a post on the VUW Students Association Facebook page (28/09/2015), (Appendix 3.8). The posters were deployed across the entire Kelburn campus on notice boards and in rest rooms.

After one week a second tranche of posters were posted and a week later (8/10/2015) school administrators were identified and visited personally with a request to communicate the surveys to staff and students in their school. The following schools participated in the circulation of the web links to the online surveys.

- $\quad$ School of Engineering and Computer Science

- $\quad$ School of Art History, Classics and Religious Studies

- School of English, Film, Theatre and Media Studies

- School of History, Philosophy, Political Science and International Relations

- $\quad$ School of Languages and Cultures

- $\quad$ School of Linguistics and Applied Language Studies

- $\quad$ School of Social and Cultural Studies

- $\quad$ School of Maori Studies, Te Kawa a Māui

- $\quad$ Executive Assistant to the Vice-Chancellor Maori

- International Institute of Modern Letters

- School of Biological Sciences

- School of Chemical and Physical Sciences

- $\quad$ School of Mathematics and Statistics

- School of Psychology

By the third week, feedback from participants highlighted a technical issue with KoBo Toolbox necessitating minor changes to the surveys. Administrators posted 
links to the revised surveys via their online school news, and in some cases posted the student survey link on Blackboard.

$\underline{\text { Analysis }}$

Survey text responses were coded using thematic analysis (Braun and Clarke 2006), grouped first into themes and then amalgamated under codes. For example, where someone had written "I pass through walking from CBD to work" in response to the question why do you go to your favourite place? I put that response into the Pass through category, or theme which was later coded to proximity along with themes referring to nearby or close to office/lecture theatre (Table 3.1).

Staff and student relative preferences for what they would like more or less of in campus green space were graphed.

Table 3.1: Themes derived from the thematic analysis of responses to the questions: "Why I go to my favourite place", and "What I like about it". These have been grouped and given code words and a code letter for the linear analysis.

\begin{tabular}{|c|l|l|}
\hline Letter & Code Words & Themes \\
\hline A & Don't use & don't use, no access, no time \\
\hline B & $\begin{array}{l}\text { Ecosystem } \\
\text { Services }\end{array}$ & sun, warmth, shelter, fresh air, outside, shade \\
\hline C & Flora and Fauna & $\begin{array}{l}\text { nature, garden, flowers, trees, grass, lawns, birds, } \\
\text { insects, green }\end{array}$ \\
\hline D & $\begin{array}{l}\text { Infra-structure } \\
\text { Services }\end{array}$ & seat, path, wifi \\
\hline E & Intellect & read, study, work, listen to music, play music \\
\hline F & Mental Health & time out, peace, relax, quiet, seclusion, escape \\
\hline G & Physical Health & run, walk, play sport, exercise \\
\hline H & Proximity & near, pass-through, \\
\hline I & Refreshment & lunch, coffee, food, eat \\
\hline J & Social & meet people, be among people \\
\hline K & View & view, beauty \\
\hline
\end{tabular}


$\underline{\text { Issues with distance data }}$

Some survey respondents clearly struggled with the mapping technology in KoBo Toolbox, judging by their comments e.g. 'the map is rubbish'. A number of staff favourite places were placed between 1-180 km from the campus (Figure 3.1).

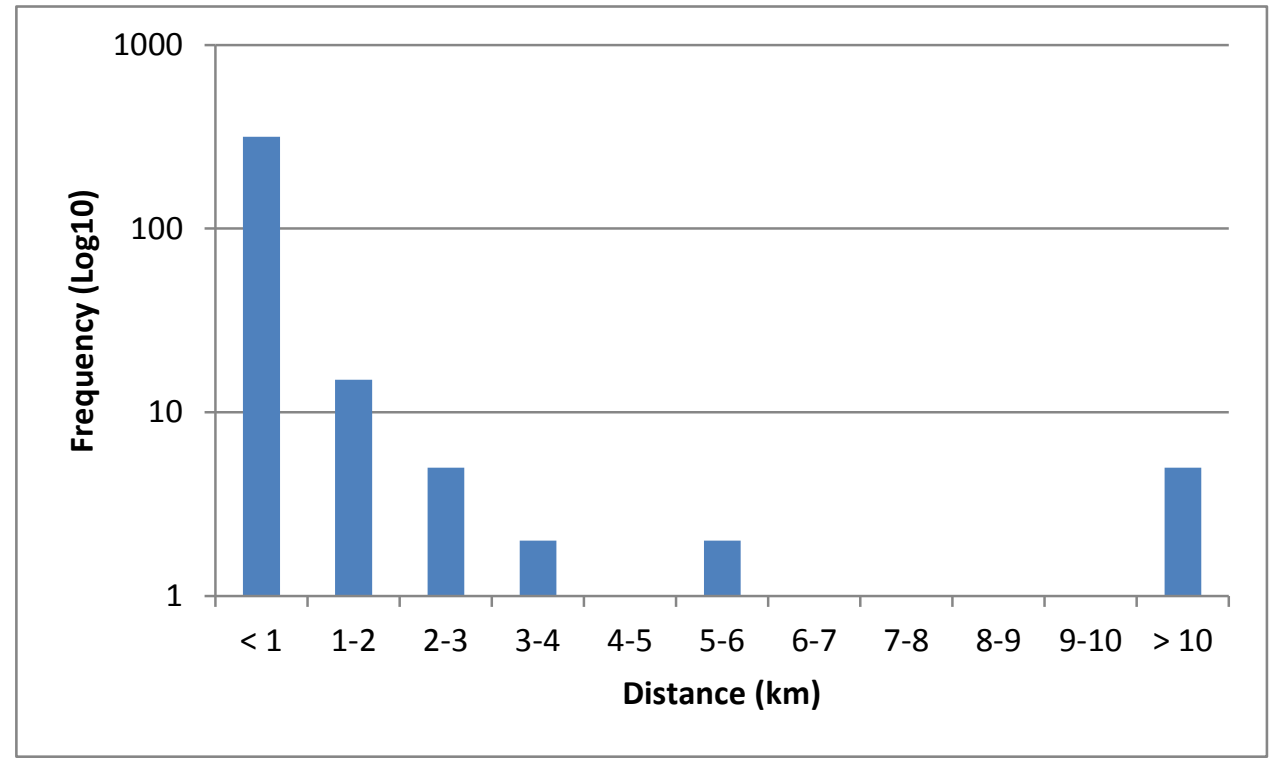

Figure 3.1: Frequency histogram for the distance all respondents (staff and students) placed their favourite places from either their office or the Hub. All results greater than $958 \mathrm{~m}$ were later removed for the multivariate analysis.

Very few students indicated that their favourite place was anywhere other than on campus or in nearby public gardens. This may reflect the difference in the way the questions were asked of students and staff. The staff were asked to respond to the phrase During my working day my favourite outdoor place to go is here; while students were asked to respond to the phrase During my day at university in Kelburn my favourite outdoor place to go is here. The survey was asking about campus green space used by staff and students, and while it became apparent that a high proportion of respondents consider that the Botanic Gardens are an extension of the campus green space, it was difficult to understand their relationships with places further afield (such as on the Miramar peninsula or Wellington Harbour), so all records with 
favourite places further from the various offices or from the Hub than the distance to the far side of the Botanic Gardens were excluded.

The removal of these records from the analysis mean that 47 rows of data were removed representing $26 \%$ and $24 \%$ of staff first and second choices respectively, and $6 \%$ and $4 \%$ of student first and second choices.

\section{$\underline{\text { GIS analysis }}$}

Geographic coordinates data, which had been downloaded from the KoBo Toolbox survey results into an Excel spreadsheet, was transformed using the LINZ online basic conversion tool (http://apps.linz.govt.nz/coordinate-conversion/). The coordinates were transformed from the World Geodetic System 1984 to the New Zealand Tranverse Mercator 2000 projection for importation into Arc Map v10.2.

Data for first and second favourite places, office sites and, for the student data, the Hub, was merged into two attribute tables, one for staff and one for students. A point distance analysis was then undertaken for each dataset to give a straight line distance for each respondent between their office, or the Hub, to their favourite places. The information from each attribute table was then exported into an Excel spreadsheet and combined.

Using Arc Map, the favourite places to visit were grouped topographically, coded, and exported into Excel for analysis (Table 3.2) 
Table 3.2: Sites commonly identified as favourite places for visiting and the codes used for analysis.

\begin{tabular}{|c|l|}
\hline Code & Site Name/Description \\
\hline 1 & Tim Beaglehole Courtyard \\
\hline 2 & Wellington Botanic Garden \\
\hline 3 & Mount Street Cemetery \\
\hline 4 & Cotton /Rankine Brown Courtyard \\
\hline 5 & East Alan MacDiarmid \\
\hline 6 & Grassy Knoll \\
\hline 7 & Hunter Lawn \\
\hline 8 & Kelburn Park /Kumutoto Reserve/Salamanca forest \\
\hline 9 & Kirk /Stout/Hunter Courtyard \\
\hline 10 & Other \\
\hline 11 & Waiteata Gardens \\
\hline 12 & Rooftop Courtyards (Kirk/Student Union/Central Services Bldg) \\
\hline 13 & No Favourite Place \\
\hline
\end{tabular}

\section{$\underline{\text { Multivariate analysis }}$}

All GIS data, was combined with the demographic data and the data from the thematic analysis ready for further analysis.

The linear analysis dataset included the following information:

- $\quad$ First or second favourite place,

- $\quad$ Site of the first and second favourite places (Table 3.2),

- $\quad$ Reasons for going to the selected first and second favourite places and what was liked about the places (Table 3.3),

- $\quad$ Frequency of visits to the favourite places in both the warmer and colder months of the year (Table 3.4),

- $\quad$ Distance in a direct line from staff offices, or for students a direct line from the Hub, to their favourite places,

- $\quad$ Status: staff or student, and

- $\quad$ Gender, age group, role and duration of time they have been at the campus (Table 3.5). 
Table 3.3: Themes for the linear analysis.

\begin{tabular}{|l|l|l|}
\hline Letter & Code Words & Themes \\
\hline A & Don't use & don't use, no access, no time \\
\hline B & $\begin{array}{l}\text { Ecosystem } \\
\text { Services }\end{array}$ & sun, warmth, shelter, fresh air, outside, shade \\
\hline C & Flora and Fauna & $\begin{array}{l}\text { nature, garden, flowers, trees, grass, lawns, birds, } \\
\text { insects, green }\end{array}$ \\
\hline D & $\begin{array}{l}\text { Infra-structure } \\
\text { Services }\end{array}$ & seat, path, wifi \\
\hline E & Intellect & read, study, work, listen to music, play music \\
\hline F & Mental Health & time out, peace, relax, quiet, seclusion, escape \\
\hline G & Physical Health & run, walk, play sport, exercise \\
\hline H & Proximity & near, pass-through, \\
\hline I & Refreshment & lunch, coffee, food, eat \\
\hline J & Social & meet people, be among people \\
\hline K & View & view, beauty \\
\hline
\end{tabular}

Table 3.4: Frequency of visits to favourite places.

\begin{tabular}{|l|c|}
\hline Survey Question Option & Frequency Value \\
\hline Several times a day & 6 \\
\hline Most days & 5 \\
\hline Once a week & 4 \\
\hline Several times a month & 3 \\
\hline Once a month & 2 \\
\hline Rarely & 1 \\
\hline Don't visit or use & 0 \\
\hline
\end{tabular}

Table 3.5: Age bands, role groups and duration groups.

\begin{tabular}{|l|l|l|}
\hline Age Bands & Role Groups & Employment/Study Duration Groups \\
\hline 25 and under & Administrative & Less than one year \\
\hline $26-35$ & Support (campus services) & $1-3$ years \\
\hline $36-50$ & $\begin{array}{l}\text { Technical (teaching and } \\
\text { research technician) }\end{array}$ & $4-10$ years \\
\hline $51-70$ & Academic & More than ten years \\
\hline & Student & \\
\hline
\end{tabular}

Gender, age class, role (student staff), duration of term at campus, and differences in green space use including: distance travelled, frequency of use, why they went there, 
what they liked about the place, and first and second choices were analysed using multivariate ANOVA in general linear models of IBM SPSS Statistics v22.

\subsection{Results}

\subsubsection{Elicitation survey results}

Twenty seven people agreed to be interviewed out of a total of 145 people approached from a staff community of 2,975 people at 30 September 2015 (Mirela Ichim, VUW HR Planning and Reporting, pers comm. 13 June 2016). Because the sample size is small the results should be interpreted with caution. The lack of enthusiasm for participation in the survey could be explained, in part, by the timing of the survey, early in the first trimester when university staff are very busy.

The School of Biological Sciences was strongly represented in the survey sample, $n=6, t s=27$. This could be because the respondents recognised the researcher or because they have a special interest in campus green space. Respondents from the School of Biological Sciences were also the only people who reported utilising resources (e.g., plants collection, or wildlife monitoring) from campus green space, although some others used outdoor space for working with students.

Fifty one percent of respondents were academics, while $33 \%$ had support roles and another $15 \%$ had technical roles. Genders were roughly equally represented (males 13, females 14) while the age distribution of respondents of both genders was roughly normal.

Respondents had a variety of interpretations for the meaning of the phrase campus green space (people could indicate more than one meaning):

- $\quad$ outdoors $(23)$

- trees/plants/vegetation (19)

- accessible to/for the use of/to share with, people (12)

- lawns/grass (11)

- courtyard/wall with plants (5), without hard landscaping/buildings (2)

- calm space away from other people and work (4)

- $\quad$ place where you can see birds (4) 
- includes indoor areas with plants/tuatara enclosure (3), specifically excludes indoor areas (4)

- $\quad$ place for recreation (2)

At this early stage in the interview three people mentioned that they thought there wasn't very much green space/plants on the campus and a fourth said they couldn't think of any areas of campus green space. When shown a map of the campus almost everyone expressed surprise at the amount of green space there was on campus. Four people considered that inaccessible places, those which could not be viewed or walked past or through, did not count as green space.

The key descriptor phrases for where participants went are listed below followed by the number who mentioned those particular spaces. There are more than 27 responses listed because participants could select more than one and many reported using a wide variety of green space areas within the campus.

- Waiteata Road (10)

- Boyd Wilson/Te Puni Village (9)

- Hunter Lawn and shrubbery (9)

- Beaglehole Courtyard (9)

- Gateway pre-construction (6)

- Von Zedlitz walkway (6)

- Mount Street Cemetery (6)

- Grassy Knoll (5)

- Salamanca Road escarpment (5)

- Escarpment from the Recreation Centre to the Boyd Wilson field (4)

- Music block (south escarpment) (1)

- Nowhere/doesn't know places/ (3)

- Karori campus (3)

- Offsite: Kelburn Park/Botanic Gardens/Kumutoto Reserve (3)

- Marae (1 Karori \& 1 Kelburn)

- Glasgow Street escarpment (2) 
- Hunter courtyard (2)

- Roof courtyard SU building (1)

- Places with seats (1)

- McLaurin green wall (1)

- Central Services Building rooftop courtyard (1)

- Tuatara enclosure (foyer beside) (1)

- Fairlie Tce (western gardens) (1)

- Mount Street walkway (1)

When discussing what they liked about a place participants spoke quite generally about birds turning over leaf litter, the depressing look of wind-blown and drought stricken sites, the importance of having warm, sheltered outdoor places with seats, and that it is less stressful to work on the Kelburn campus than in any office in the CBD. There was strong consensus around the feelings of well-being that accrued from having usable or viewable green space nearby.

Key descriptor phrases for what they did in green space were:

- Recreation Theme Walk through (16), Eat lunch in (4), Run through (3), Sit on grass (3), Hang with/meet people (2

- Mental Health Theme: Rest and relaxation (7), Views it from indoors (12)

- Education Theme: Use as outdoor classroom/therapy space/show visitors (6), Collect material for labs/classes (5)

- No opportunity to get out into green space \& minimal views (6)

- Goes off campus for green space experience (3)

Key descriptor phrases for what was important to them about green space were: Human health, nature, education, biodiversity, and branding.

What else did they have to say about campus green space?

A strong theme amongst participants was leafiness and this was followed by accessibility. If it could not be walked in, sat in, or used by people in some way then an area was less likely to be considered green space. Participants were divided about whether or not the tuatara enclosure was green space and those who thought it was not usually said it was because they could not go inside with the tuatara. This is a 
contradiction to the opinion that green space is not accessible. (The tuatara enclosure is a small courtyard open to the weather, but protected with shade cloth. It is enclosed on all four sides, with three of the walls having windows onto the indoor foyer of Murphy building.)

Other key themes were that green space should be readily identifiable as green space and accessible; that it had ecological values; that it was important for branding and for education; that some green spaces were better than others; that effects of development on campus was not always positive for green space; that indoors can be green space; that the culture of members of the university community was not well recognised in terms of the provision of green space; and, that there could be better consultation with the university community regarding campus green space. One person commented that he enjoyed watching construction sites, but others mourned the loss of gardens and commented that they had not been consulted about this. They appreciated that someone was asking them about campus green space.

One of the participants commented that in three years no one had ever shown her a nice place to go outside. In fact she had been unable to find anywhere with green space near her office that she would like to spend time in. A number of participants had recently read about the award winning indoor gardens in Changi Airport Singapore and this influenced them when they talked about campus green space. They felt strongly that the campus lacked beautiful, warm, sheltered outdoor spaces that were leafy and had flowers as well as seating and good access. Campus green space, they said, was too steep and inaccessible. If it could not be created outdoors because of environmental conditions then they questioned why there couldn't be an indoor garden with water features, or even a butterfly garden.

A recurring theme was the lack of information about routes of pathways, and the general shortage of outdoor seating.

\subsubsection{Staff and student online survey results}

The elicitation survey informed the design of the online survey by highlighting the variety of places those early participants visited both on and off campus, and the variety of things they did when they were there. Seventy-four staff and ninety-nine students responded to the email survey. This is from a university staff population of 
2,975 at 30 September 2015 (Mirela Ichim VUW HR Planning and Reporting, pers comm. 13 June 2016), and a student population for 2015 of 21,457 (Rafiq Mahommed VUW Business Intelligence Analyst pers comm. 27 May 2016).

As with the elicitation survey, the respondents were self-selected rather than a random sample selection, and sample sizes were small compared to the populations $(2.5 \%$ of staff and $0.5 \%$ of students).

The staff who responded were mainly academics (51\%) with the rest having administrative positions (23\%), support positions (16\%), or technical positions (9\%).

The response rate was not representative of the staff or student population demographics, with a higher response rate from older people than from those in the under 25 year olds group (Figures 3.2 and 3.3). In particular, the response rate was disproportionately high from the 51-70 years old age band of the staff cohort, and disproportionately low for the 26-35 years old age band of the student cohort. In each of these groups there were more male survey respondents than females.

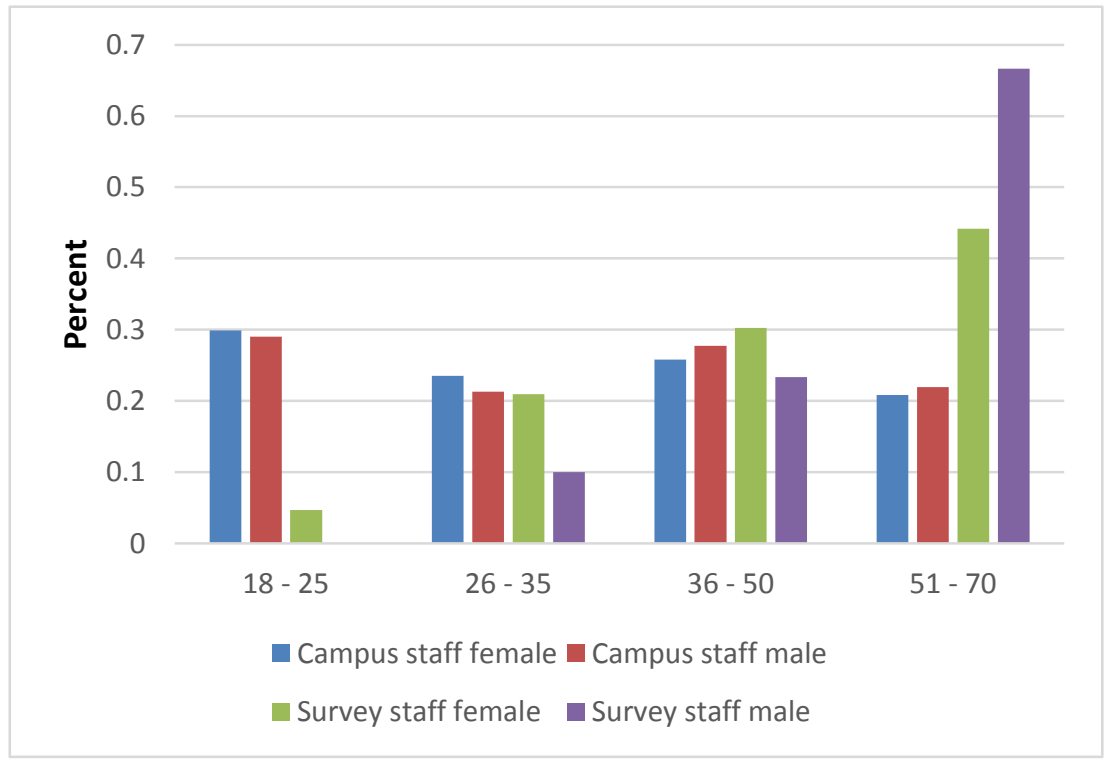

Figure 3.2: Relative age of campus staff and surveyed staff sorted into age bands. 


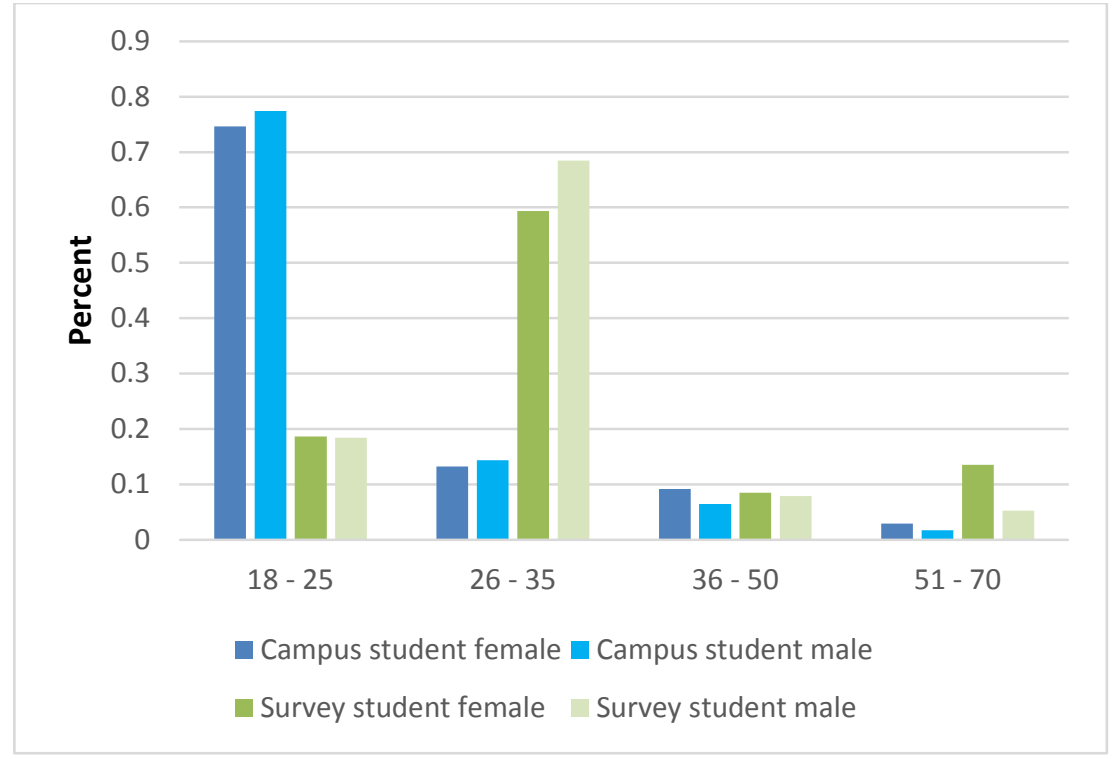

Figure 3.3: Relative number of campus students and survey students in each age band. 
$\underline{\text { Gender, age and role effects }}$

Multivariate analysis in SPSS showed that gender did not significantly influence staff or student use of green space in and around campus (MANOVA, $F_{38,254}=1.35$, $P=0.097)$. An exception was that more females than males (both students and staff) stated a preference for warm and sheltered sites (Figure 3.4). Females' preference for warm and sunny is demonstrated for both why they go to a site as well as why they like the site indicating a particularly strong preference for warmth and shelter. Male students identified sun as a reason for liking their chosen site, but not as a reason for going there. (MANOVA, Go there because warm/sunny, $F_{1,291}=9.23, P=0.003$; Like because warm sunny, $F_{1,291}=6.44, P=0.012$ ). Analysis by gender did not identify significant differences for place, distance or any themes other than warm/sunny (Ecosystem Services).

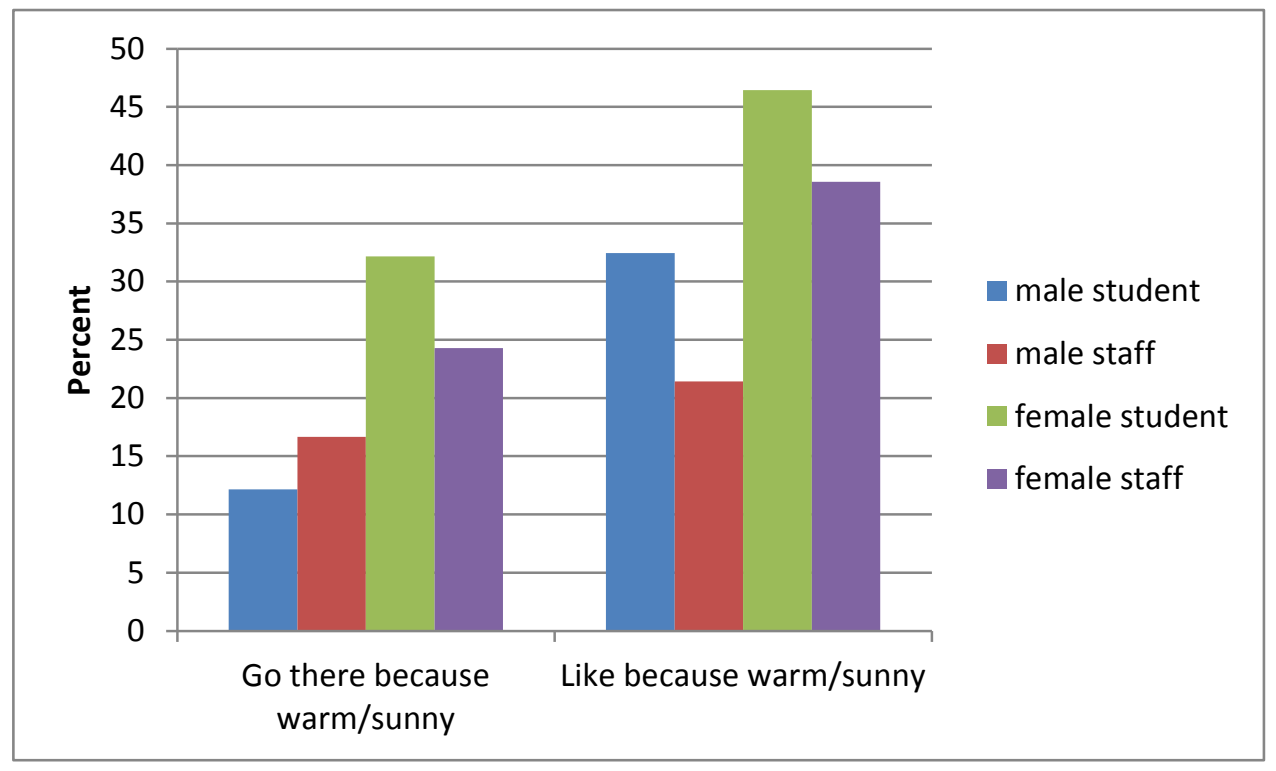

Figure 3.4: Relative differences between numbers of males and females preferring warm places in campus green space.

There was a significant overall difference in green space use by age (MANOVA, $\mathrm{F}_{38}$, $259=3.48, P=0.001)$. In particular staff and students under the age of 50 were strongly represented as favouring the Tim Beaglehole Courtyard as their favourite place, while those over 50 had a strong preference for visiting the Botanic Garden (Figure 3.5). Also, a significant number of 26-35 year olds had a preference for the 
Kirk/Stout Courtyard (MANOVA, Beaglehole CY $F_{3,294}=4.61, P=0.004$; Botanic Garden $F_{3,294}=4.32, P=0.005 ;$ Kirk/Stout CY $\left.F_{3,294}=4.00, P=0.008\right)$. Reasons for visiting and what they liked about their favourite place were not significant for age.

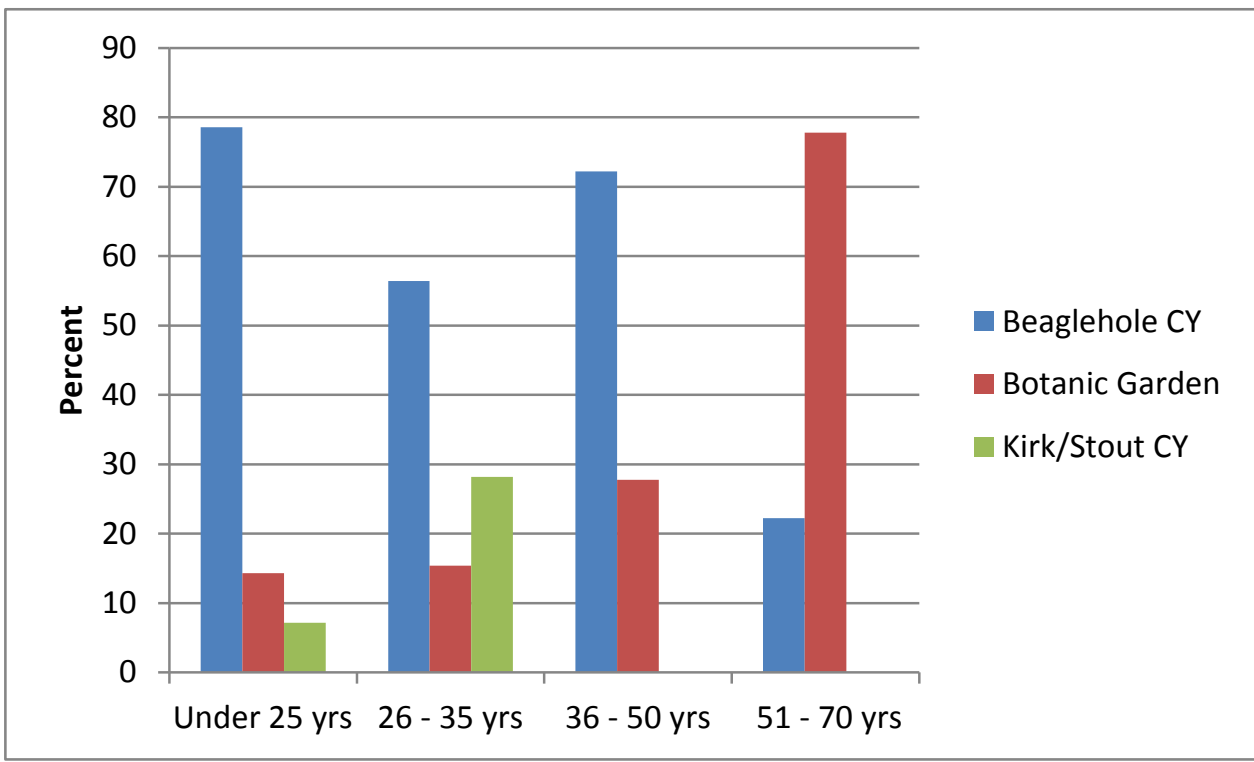

Figure 3.5: Places where there were significant differences in the ages of staff and students choosing to visit. 
There was a significant overall difference in the ways staff and students use campus green space (MANOVER: $F_{23,274}=3.12, P=0.001$ ). More specifically, students were more likely to use green space for reading and studying, relaxation, and social connection; while staff were more likely to use green space for physical exercise, and connecting with nature, and were likely to stay closer to their offices (MANOVER: intellectual pursuits $\mathrm{F}_{1,296}=6.53, \mathrm{P}=0.001$; mental health $\mathrm{F}_{1,296}=14.73, \mathrm{P}=0.000$; physical health $\mathrm{F}_{1,296}=13.99, \mathrm{P}=0.000$; flora and fauna $\mathrm{F}_{1,296}=3.95, \mathrm{P}=0.48$; proximity $\mathrm{F}_{1,296}=3.97, \mathrm{P}=0.047$ and distance $\mathrm{F}_{1,296}=15.46, \mathrm{P}=0.000$ ), (Figure 3.6). All other factors, and themes for explaining people's choices for visiting a site and what they like about it (place, non-use, ecosystem services, infrastructure services, refreshment, social and view), were not significant (see Table 3.3 for descriptions of the themes).

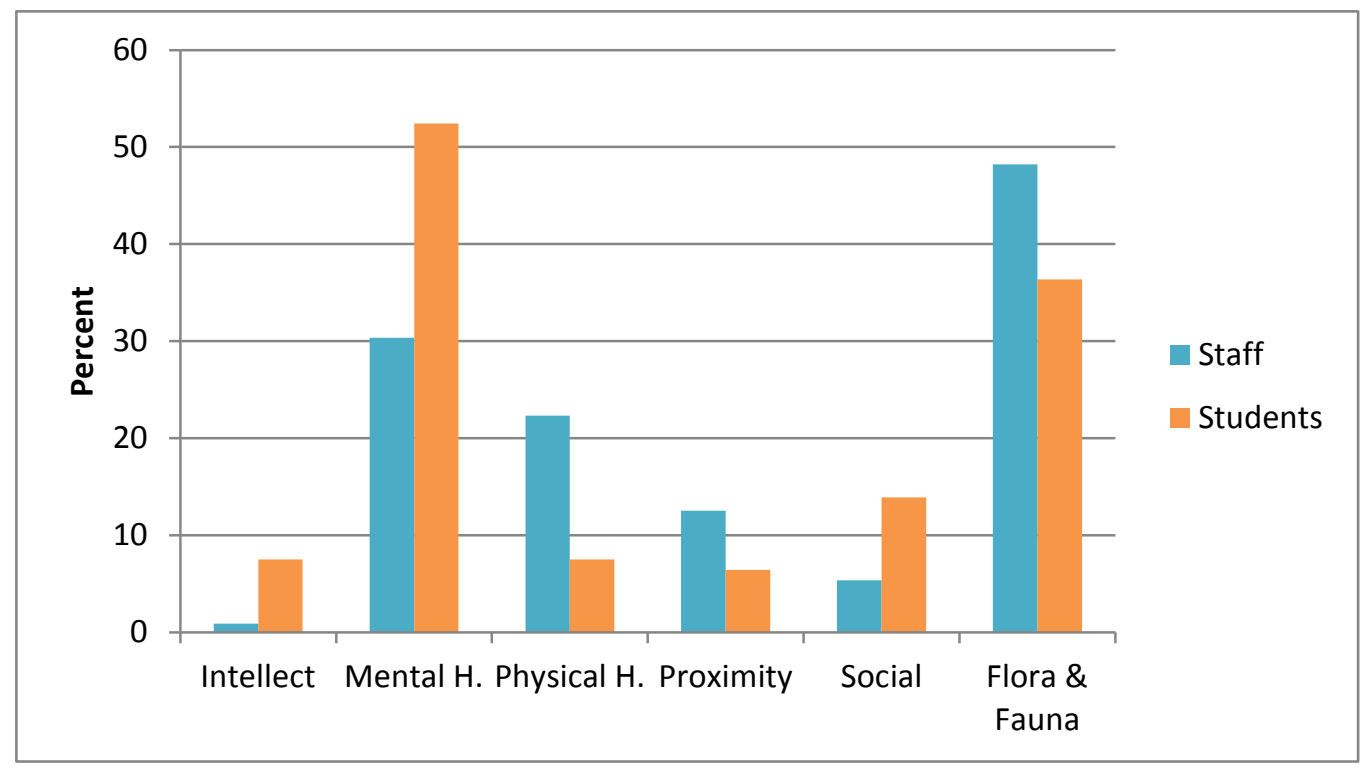

Figure 3.6: Relative numbers of staff and students identifying various reasons for use of campus green space.

\subsubsection{Favourite green space places}

Students tend to stay on campus when accessing green space with a number of hotspots standing out (Figure 3.7). The grassy knoll at the top of the Mount Street path ( $7 \%$ of students) and the Mount Street cemetery (12\% of students) combine to make the largest hotspot, closely followed by the Tim Beaglehole Courtyard (15\%). 


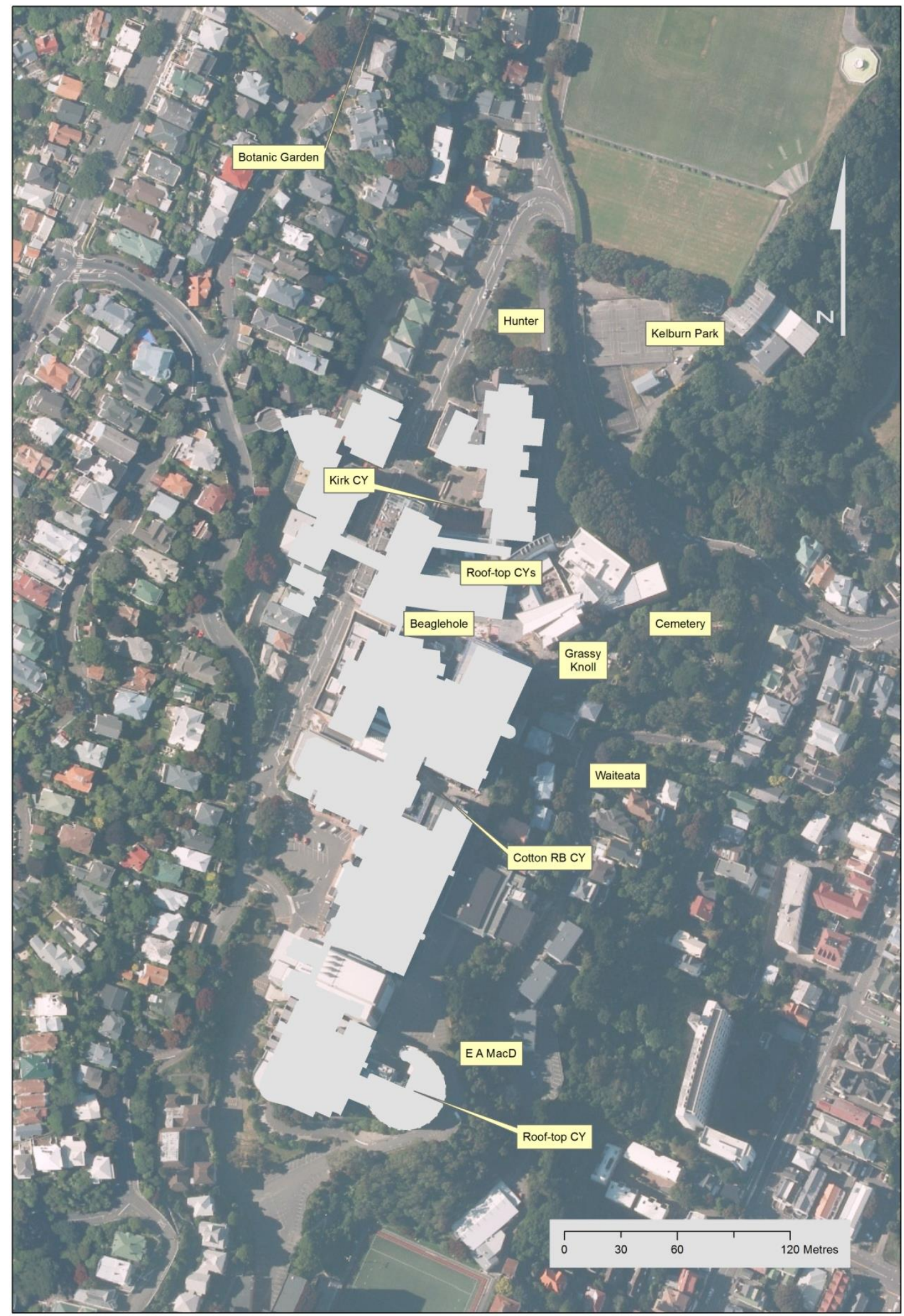

Figure 3.7: Hot spots favoured by staff and students at Kelburn campus.

Other student hotspots are the eastern side of the Alan MacDiarmid car park (9\%), Hunter lawn, Waiteata Gardens and Hunter Courtyard (all with 5\%). When moving 
off-campus students showed a preference for the Botanic Garden (9\%), Kelburn Park $(2 \%)$ and Kumutoto Reserve (2\%).

Staff had a much greater tendency to indicate off-campus places than students, although the reasons for this are unclear. Far more staff than students use the Botanic Garden (Figure 3.8). Fewer staff than students stayed close to their offices (Figure 3.9).

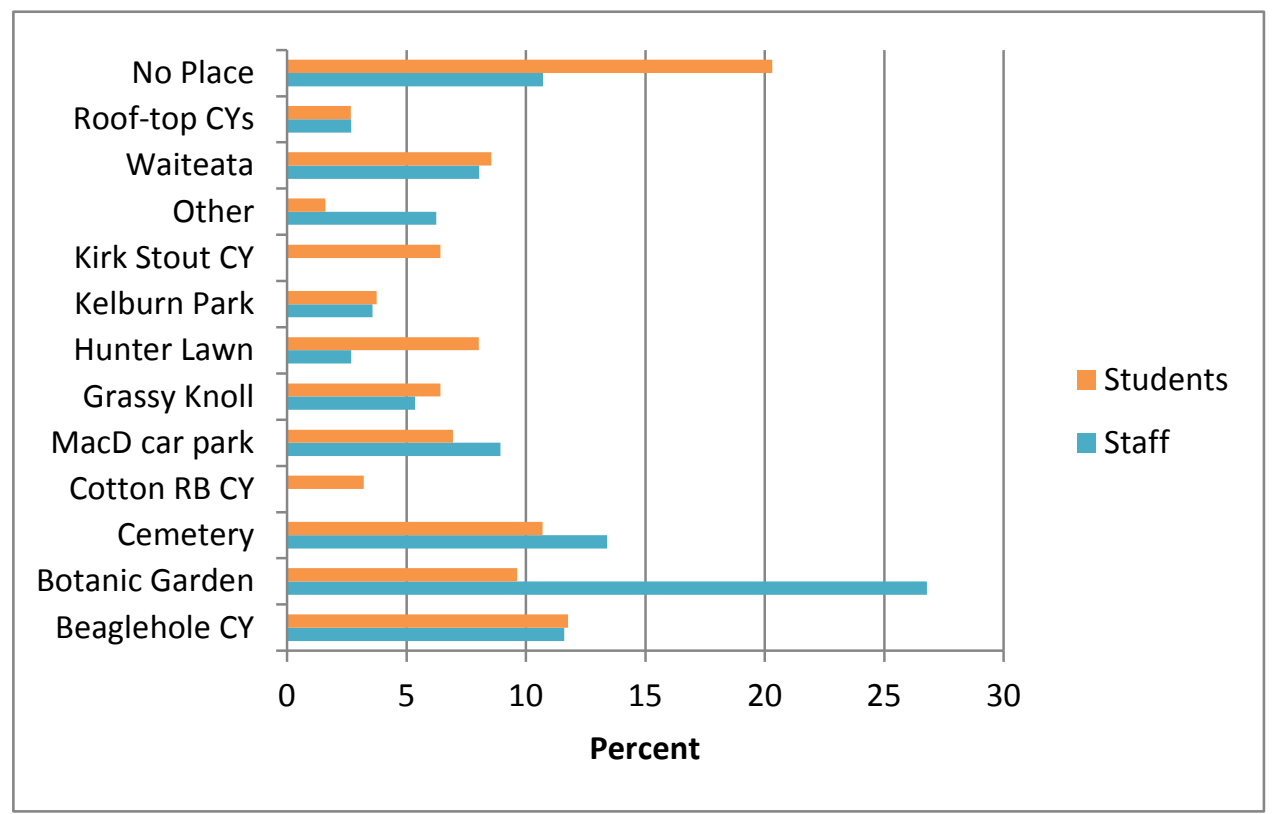

Figure 3.8: Favourite green space places and the relative number of staff and students who showed a preference for them. 


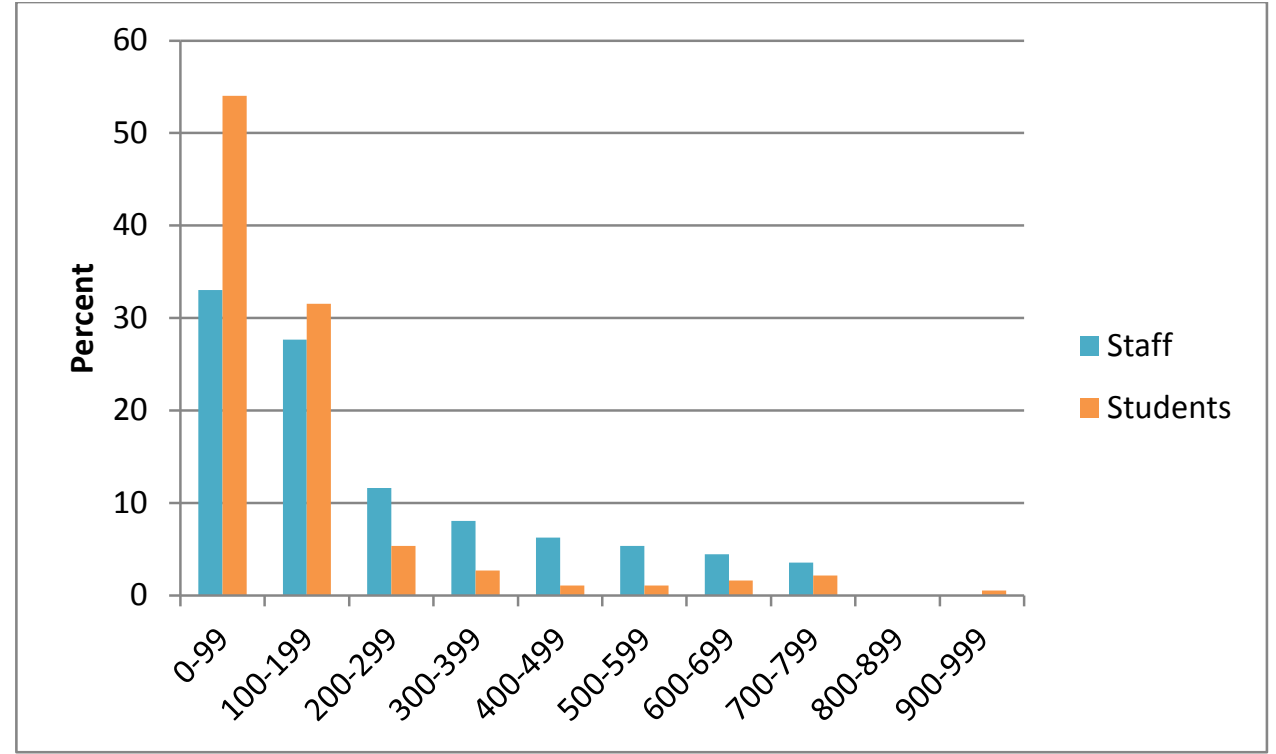

Figure 3.9: A histogram of the relative distances survey respondents would need to travel, as the crow flies, to access what they say are their favourite green space places to go to when at the Kelburn campus.

A high number of participants commented that there was not enough green space and that better facilities would make green space more accessible (Table 3.6). Fewer people mentioned issues related to biodiversity. This is reflected in the result that participants wanting better gardens and managed wilderness outnumbered those wanting fewer weeds. 
Table 3.6: What would give staff and students greater access to Kelburn Campus green space? (Note that there were multiple comments from some respondents so the total number of comments (223) is greater than the total number of participants (173).)

\begin{tabular}{|l|l|c|}
\hline Theme & Comments & $\begin{array}{c}\text { Number of } \\
\text { Comments }\end{array}$ \\
\hline More green space & Not enough green space on campus & 63 \\
\hline Facilities & $\begin{array}{l}\text { Sociable design, seating, tables, paths, wifi, power, } \\
\text { views, wheelchair access }\end{array}$ & 32 \\
\hline Get Smart & $\begin{array}{l}\text { Maximise potential by making better use of } \\
\text { available GS including: better gardens, flat lawns, } \\
\text { managed wilderness, fewer weeds, quality, rooftops }\end{array}$ & 19 \\
\hline $\begin{array}{l}\text { Location, location, } \\
\text { location }\end{array}$ & $\begin{array}{l}\text { Closer to office, more at Laby end, more at VZ and } \\
\text { M, more in central area }\end{array}$ & 18 \\
\hline Shelter & Sun, warm, dry, heaters & 16 \\
\hline Time & Too busy (staff and part-time students) & 16 \\
\hline Information & $\begin{array}{l}\text { Where is the green space? Is there any left? Hardly } \\
\text { any of significance, maps, signage }\end{array}$ & 12 \\
\hline No comment & & 47 \\
\hline
\end{tabular}

\subsubsection{Wish lists- things that staff and students want more, or less, of}

Staff and students were in agreement when asked about what they would like more, or fewer, of with regard to campus green space (Figure 3.6). Top of the list of what they want more of ( $73 \%$ of staff and $84 \%$ of students) is sunshine. This is followed by native birds (62\%:69\%), seats (61\%:55\%), large trees (49\%:62\%), native plants (54\%:53\%), flowers (49\%:56\%) and lawns (36\%:54\%). This latter feature is the one with the greatest disparity between staff and students (Figure 3.10).

When it comes to things they want less or fewer of there is even stronger agreement between staff and students (correlation coefficient 0.97). Sixty-six percent of staff and $59 \%$ of students reported that there was nothing on the survey list that they wanted fewer or less of. 


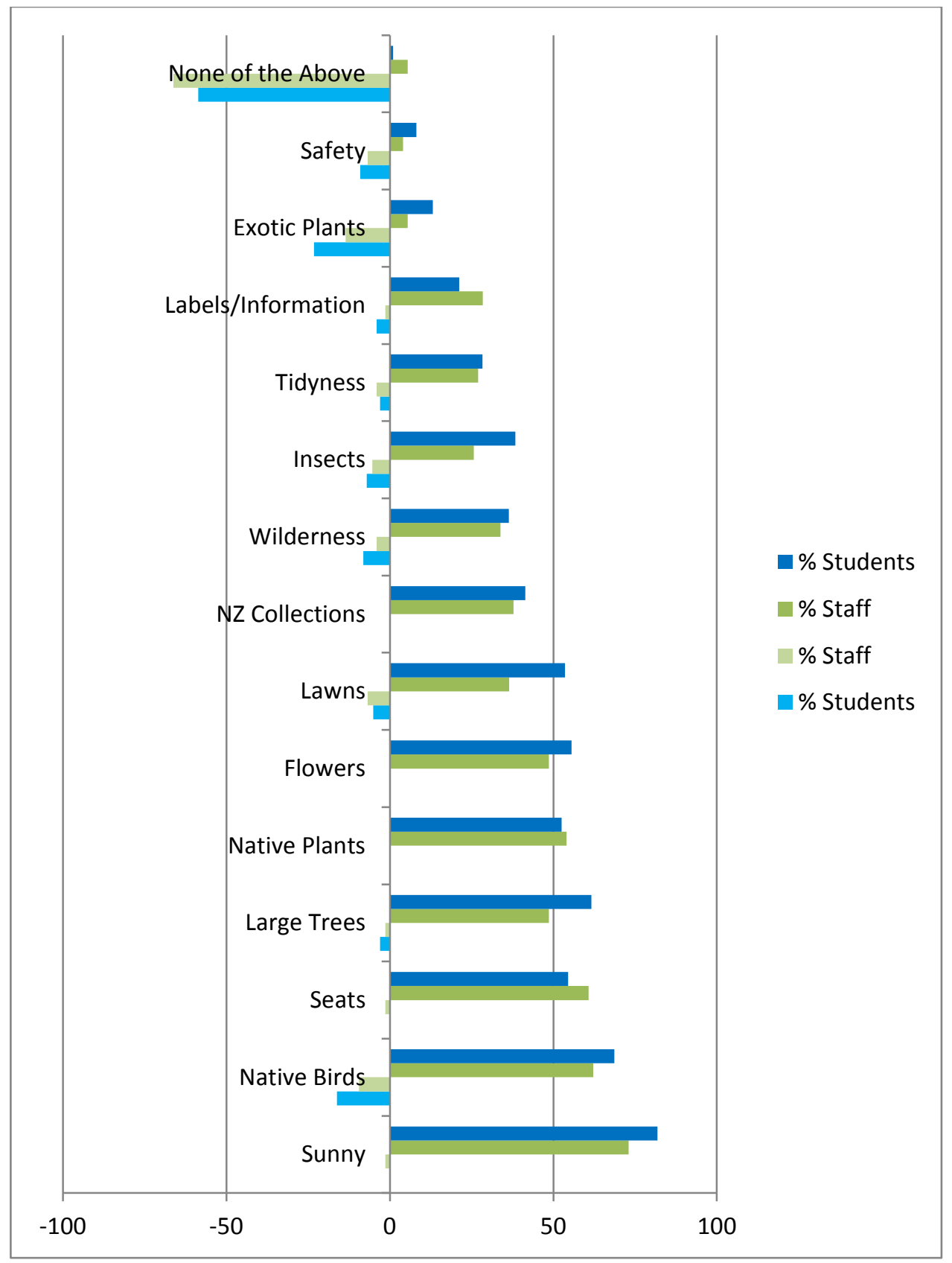

Figure 3.10: Results of the survey questions asking staff and students what they would like more (the positive responses), or fewer (the negative responses), of with regard to campus green space. The numbers are proportional, allowing staff responses $(n=74)$ to be compared with students $(\mathrm{n}=99)$. 


\subsection{Discussion}

\subsubsection{Elicitation survey}

\section{Meaning of the phrase campus green space}

Four strong themes were apparent when interviewees talked about what green space is: place (outdoors), signifier (plants), activity (accessibility), and human health (mental and physical).

However, participants were vague about what features of green space mattered to them and it was clear that the planned email survey would require more specific questions.

\section{Where participants went}

It was very interesting and useful that interviewees had a better response when prompted by a campus map. It was also interesting to know that people generally did not have names for the places that they went. This suggested that asking respondents to mark locations on a map would be a more effective way of finding out where people went than simply asking them to name places. I also determined that many people experience campus green space as an action secondary to doing something else, for instance they walked through it on the way to work or ate their lunch there. This is what informed the "why do you go there?" question and helped with teasing out the themes from the email survey replies.

Views from staff offices appeared to be important because they were mentioned often, in both positive and negative ways. However, as with cultural values of green space, this line of enquiry was too time consuming to pursue in this piece of research.

Access was discussed during the interviews but proved to be a difficult subject to develop questions about because of the wide variety of opinions about what access meant or applied to. None of the interviewees raised the subject of personal security from unwelcome contact with other people so I did not include such questions in the following survey. 


\section{$\underline{\text { Use of campus green space }}$}

It became obvious fairly early on that many people considered City Council reserves and gardens close to the campus as being a part of the campus and is the reason I included those areas in my final analysis. Participants became quite animated by the question of how they used green space. That is, while most of their responses were prosaic (they did things in it), three participants waxed lyrical about bridging the natural and built environments, places they are allowed to be in, and of lifting oneself out of the mundane. This meant that this survey question would need a comment answer rather than a multi-choice.

\section{What was important to them about campus green space}

Participant responses were aligned with the literature regarding the roles and benefits of nature for the workplace (Kaplan 1993; Kaplan 1995; Berto 2005; Horowitz and Kretsch 2015) and also with on-campus studies (Oppezzo and Schwartz 2014; Wu et al.). I allowed a comment response for this question in order to capture as many answers as possible.

\section{What else would they like to say about campus green space?}

The questions in the email survey about what people wanted more or less of were a way of capturing more direct information on subjects distilled from the interviews. Although based on a lot of negative responses from interviewees these questions were phrased, where possible, in neutral language. An attempt was made to have two identical lists so as not to lead people into thinking that there were right or wrong answers.

At the time of the survey, the University had begun work to remove campus trees to make way for a new building. This was mentioned by many interviewees, some of whom were glad to have the opportunity to talk about this loss of campus green space.

\subsubsection{Email survey}

The email survey addressed several of the issues raised by the elicitation survey. In particular by asking the same question in a number of different ways and allowing some responses to be written in the respondent's own words and others to be limited 
to a fixed number of options. It was important to capture issues raised in the elicitation survey, such as places having access, warmth and seating, while allowing potential new issues to be raised. Demographic information was useful for comparing the samples with the campus community as a whole as well as within various groups of the sample.

That the age of participants was generally higher than in the campus population was interesting. It could reflect the likelihood that older staff and students have themselves been in the position of wanting to survey the campus community and therefore feel more inclined to reciprocate.

The issue of the respondents who selected places more than a kilometre from campus was a difficult one to resolve. The elicitation survey showed that many people considered that green space close, or adjacent, to the campus counted as campus green space. These areas included: Mount Street Cemetery (owned by the Catholic church and maintained by the university and a 'Friends' group); Kumutoto Reserve (Council Reserve and site for student research and a student run 'Friends' group); Kelburn Park (Council playing field used by university sports groups); and Wellington Botanic Garden (Council reserve). There seems to be a strong case for including these places in the survey analysis given that the survey technology allowed them to be identified and separated from actual campus green space where necessary.

The removal of data from participants who travelled further away was justified on the grounds that the surveys' area of specific interest was campus green space.

The email survey provided useful information about differences in the use of green space according to gender, age and role. There appears to be a big difference between the ways staff and students use green space although they appear to be agreement on what they would like more or less of with regard to campus green space. There are also differences in where people like to go according to their age although this could be explained by the disproportionate response from staff in the 51-70 age band. The use of green space by males and females was largely similar, with the exceptions being female students and staff who signalled a preference for warm sunny places, and male students who indicated that they didn't necessarily go to a place because it 
was warm and sunny, but who definitely liked that it was warm and sunny when they were there.

Distance did not seem to be a significant factor in the way people used campus green space. However, the data for this was calculated on an 'as the crow flies' basis rather than by using Manhattan distance (the sum of horizontal and vertical components) which may have been more accurate. Measuring student distance from the Hub is also potentially flawed. However, students mostly seem to stay within several hundred metres of the Hub anyway. The Hub is a warm and central indoor area with a wide variety of facilities and easy access to the Tim Beaglehole Courtyard.

Based on the results of this survey, and taking into account that campus population may double in next few decades, I make the following recommendations:

1. Improve access to campus green space by providing information about where paths and seating in, and near, green space are located, and depicting what people might see and hear if they follow the paths.

This recommendation is based on elicitation survey results that showed people did not know the kinds of green spaces there are on campus. It also reflects email survey results which showed that, in general, people did not travel very far to reach their favourite place, and that they wanted more of some things such as birds, native plants and large trees which are already present on campus but not well known. Orr et al, (2014) found that it is important that people are able to discover and value access to green space. This is something that cannot happen on campus at present due to the lack of information.

2. Develop existing courtyard areas to enhance the warmth and shelter they provide while maintaining and enhancing natural elements within them such as large trees, native plants, flowers and lawns.

This recommendation is based on the relatively low use rates of many of the campus courtyards, and the expressed preference of respondents for warmth and shelter and natural elements. 
3. Identify potentially warm, sheltered places along campus paths alongside green space areas and enhance them by providing wind protection and seating, with canopy gaps that allow sun to reach the seats, and by establishing interesting plants.

This recommendation is to address the low use rates for a number of campus garden and wilderness areas that provide the natural elements that staff and students expressed a desire to experience but which are currently not readily accessible. For example; the escarpment above the Music Department, the pōhutukawa forest above Salamanca Road, Waiteata Road gardens, and the kānuka/eucalypt forest above the Boyd Wilson field.

4. Address the current lack of capacity of paths and seating on campus to avoid future conflict between those seeking rest and relaxation and others seeking physical exercise.

The theme of mental health is given as important by a high proportion of respondents. The levels of relaxation provided by using paths and seating to access green space is likely to diminish if the number of people using these same places increases substantially. People are unlikely to travel far to a highly favoured area if the competition for that place is high, resulting in more pressure on closer favourite places.

\subsection{Conclusions}

The email survey showed that the campus community have a strong preference for usable outdoor space that is warm and sunny, has good access and where seating is provided. This is unsurprising given that being in sunshine for short periods is highly beneficial for human health (e.g. Holick and Jenkins 2003; Mason et al. 2011, Tornhammar et al. 2014; Sandifer et al. 2015) in particular for women's health (Zhou and Rana 2012). Provision of facilities such as seats, and the implied access to them, has also been shown to be valued, for example in Hong Kong (Lo and Jim 2012; Hadavi et al. 2015; Wan and Shen 2015). Orr et al. (2014) found, when researching for a University College of London policy briefing paper that the local context of green spaces was important especially understanding local evidence for different 
areas. The university community comprises people of all ages and from many different backgrounds. My research shows that different people want different things from green space, therefore a one size fits all approach is not likely to be successful.

Both staff and students use campus green space but they value it in different ways. Students value green space where they can be with or near other people and also where they can relax, keep warm and do some reading or study. This aligns with research that shows that students' success at school is positively correlated with the 'greenness' of the school surroundings (Wu et al. 2014). Although the literature shows that younger people tend to use green space for more active pursuits (Matsuoka and Kaplan 2008), it is male campus staff in this study who value green space for physical health, and move further away than students to get to their favourite place. This might be because students exercise off-campus or in gyms, after school, while staff (being older) may have other obligations later in the day and need to use their lunch break for exercise. Staff may also be seeking the positive effects of exercise on creative thinking as reported by Oppezzo and Schwartz (2014).

The implications of this study are that, as the campus population grows, demand for access to usable green space may outstrip supply. Those staff who have the time will continue going to the Botanic Garden, while those who are time poor may be left with less access to green space except for densely populated areas close to their offices. There is also likely to be an increase in the number of people reporting that they do not have access to a favourite green place. Under pressure of increasing competition for access to warm and sheltered green space close to the Hub, students' academic achievement may fall, particularly in the winter months and for students in poor quality accommodation. This, in turn, would increase the pressure on those providing student support such as medical and counselling services, and could affect the University's reputation. Implementation of the recommendations above would go a long way towards addressing these issues. 


\section{GENERAL DISCUSSION}

\subsection{Introduction}

Urban green space is composed of street trees, parks and reserves, riparian vegetation, recreation areas, and institutional and residential gardens. Given the current worldwide decline in biodiversity (WHO 2015) these pockets of plants and wildlife are increasingly valued for multiple benefits: species protection and conservation, habitat protection, amenity and cultural values, and ecosystem services. They are also valued for the ameliorating effects they have on the process of climate change e.g. carbon sequestration. Despite this, urbanisation is responsible for the loss of a large number of indigenous species (McKinney 2010). It takes time for the effects of urbanisation to become apparent due to the long lag times between the onset of the effect and the outcome (Sarukhán and Whyte 2005; Cronk 2016) and the effects are difficult to measure McDonald et al 2013).

Victoria University of Wellington's Kelburn campus supports garden and wilderness areas totalling 3.85 ha. If managed appropriately this vegetation could make a significant contribution to city biodiversity values by providing connectivity, plant and animal propagules, genetic diversity, and a haven for indigenous species. It would also contribute to better relationships with neighbours and stakeholders.

The campus gardens also provide valuable services for staff and students including health, amenity, and education and research opportunities. With projected increases to the student population of the campus these services could come under pressure. This would reduce the value of those services to both students and staff.

\subsection{Campus vegetation}

At the completion of this campus vegetation research project I have determined that the campus has moderate biodiversity values. This does not compare well with other Wellington green spaces. It differs from both the remnant indigenous forest in the nearby Botanic Garden and the regenerating indigenous forest in Waimapihi Reserve in that it lacks a number of the species occurring in those two areas, and which might 
be expected to be present in any reasonable sized Wellington indigenous forest block. These include: tāwa, kohekohe, kōtukutuku, pukatea and rimu. The campus site differs from other green space in the city in that much of the soil was stripped during the various development phases and has never been replaced. Other bush blocks in the city have lost some, but not all, soil due to erosion following the removal of the original forest cover by Māori and early European settlers. However, the lack of good soils on the campus means it is unable to support a full range of local species. The exposed site will also limit the success of some local species.

The vegetation also includes a number of invasive plants which are recruiting into the canopy. This is unusual compared with a public garden or reserve in Wellington City where weeds are generally monitored and controlled (WCC 2015).

Finally, species richness, which rose to a high of 246 species in 1990, now stands at only 177 species, a significant loss, which mainly concerns introduced species. Species richness could fall even further given that 82 species have only 1-4 representatives on campus. What is also interesting regarding the decline in species richness is that there are no vegetation removal controls applicable to the campus under the Institutional Precinct rules of the District Plan. This differs from rules for the university's residential neighbours for whom removal of more than $100 \mathrm{~m}^{2}$ of vegetation is not a permitted activity (Myfanwy Emeny, WCC pers comm. 2/08/2016). The fact that the university cleared just over five percent of campus vegetation recently to make way for development illustrates just how vulnerable the campus vegetation is.

A thorough search of the literature failed to produce any studies directly comparable to this one. A survey of Christchurch urban forest patches undertaken by Stewart et al. (2009) assessed species richness but was not restricted to woody plants as this one was. Also the suite of indigenous plants naturally occurring in Christchurch differs from that in Wellington. The Christchurch survey was interesting in that it found that indigenous canopy dominants included Sophora, Nothofagus, and Podocarpus all of which are rare in the Kelburn canopy; at least since the loss of the Sophora molloyi grove outside Cotton. Much of this is explained by the long history of amenity planting in Christchurch and the topography of that city which means that soils have generally been better preserved. 
Although both Massey University (Palmerston North) and Unitech Technical Institute (Auckland) are reported, on their websites and in the grey literature, as having undertaken campus plant inventories there is nothing in the academic literature regarding these surveys. The Unitech inventory revealed that more than 200 species of trees were present on the campus compared with 177 on the Kelburn campus (Anon 2013). The Auckland campus was also said to have a number of rare species but how many was not reported. The Kelburn campus vegetation includes 17 species that are 'At Risk' or 'Threatened'. I am not able to say whether or not this is an exceptional number for a New Zealand campus.

My study was limited by being unable to accurately GPS individual trees and by having insufficient time to survey the VUW Karori campus. It would have been good if I had been able to create a map showing rare and unusual trees on the campus. It would also have been useful to compare the two campuses although they are very different. The Karori campus is far smaller and almost flat, and the gardens were developed from scratch in the early 1960s on deep clay rather than the rock of the Kelburn campus.

The strengths of my study are that not only has a full inventory of campus trees been recorded, but historic campus records, which were close to being lost, have been gathered together here for comparison. Those records are also now appropriately archived.

There are a number of areas where further research of campus vegetation could help with future management. These include the food values of Pseudopanax crassifolius x lessonii hybrids compared with the local five finger (Pseudopanax crassifolius), more information regarding the likelihood of the hybrid Pseudopanax outcompeting five finger and the potential for five finger to become locally extinct. It would also be very interesting to survey the soils of the campus in order to determine sites with high biodiversity potential. Finally, the conflict between university sustainability policy and District Plan Institutional Precinct rules needs to be explored in order to provide greater protection for campus vegetation. 


\subsection{Staff/student campus values}

My study into the values the campus community have for campus green space showed that people generally, and especially women, have a strong preference for warm, sunny, accessible outdoor space. This is consistent with what has been reported in the literature (Jim and Chen 2006; Lo and Jim 2012) although it must be recognised that few studies directly consulted people on how they valued urban green space (UGS). Rather, there are a great many studies that look at whether or not physical or mental health outcomes are influenced by UGS (Berto 2005; Home et al.2012; Horwitz and Kretsch 2015); and whether views of, or access to, green space is good for people at work (Kaplan 1993; Kaplan 2007; Oppezzo and Schwartz 2014).

My findings on gender and role differences regarding use of green space are also consistent with the literature (Fang et al. 2011). Again other such studies focus on determining what people should need rather than what they want (Matsuoka and Kaplan 2008).

Staff in my survey were found to be less likely than students to stay near to their offices, and male staff, in particular, were more likely to go to their favourite place for exercise while female staff and all students were after rest and relaxation. A high number of people mentioned that there was not enough green space and that better facilities would make green space more accessible. Facilities they suggested included power points, heaters and shelter. No one mentioned access to toilet facilities or personal security although these issues have been raised in the literature (Krenichyn 2006; Jorgensen and Anthopoulou 2007). Few people referred directly to biodiversity. This may not necessarily be because they do not understand the word or the concept but because they have words from common usage that describe aspects of biodiversity such as leaves rustling and birds singing.

The results of my survey were not unexpected and I am in agreement with Hadavi et al. (2015) when they suggest that it is 'advisable to investigate residents' needs and preferences before making decisions on planning and design'. Muratet et al. (2015) were also of the opinion that 'citizens' knowledge, perception and needs' should be taken into account when developing conservation management plans. Age did make a difference for green space use with younger people preferring the Beaglhole 
Courtyard and older people preferring the Botanic Garden. This was consistent with the findings of Jorgensen and Anthopoulou (2007).

What was new about my study was the recording of where people went and how far that was from their work place. This adds to a new dimension to our understanding of how people use green space when at work or travelling to and from work.

Further research particular to the VUW Kelburn campus could focus on how to advertise the green space currently available; how to provide more of the favourite types of green space for a growing population; how to make existing favourite places better in terms of provision of natural and infrastructure elements; and design aspects of pedestrian corridors to ensure that they take enough people where they want to go, in a comfortable manner, and are sized for future populations.

\subsection{Recommendations}

Through my research I have demonstrated that significant biodiversity gains can be achieved through more effective management of campus green space. This would also improve relationships with neighbours and stakeholders, and bring campus biodiversity management in-line with local government policy. In addition, I have identified green space values that are important to the campus community and which, if built upon, could result in the green space becoming a significant draw-card for students and staff alike.

1. Research into the food value for birds of Pseudopanax hybrids compared with local Pseudopanax species.

2. Research into the likelihood of local Pseudopanax species being forced into local extinction by hybrid species.

3. Develop a pest plant management plan.

4. Determine which soils in campus green space areas have high biodiversity potential and select plants accordingly.

5. Determine the needs of the multicultural campus community for green space.

6. Promote green space areas to staff and students as destinations and provide explanatory information regarding the natural values of particular sites. 
7. Enhance natural and infrastructural elements of green spaces with planting, pest control, seating, shelter, and canopy gaps for sunshine.

8. Review access routes for pedestrian comfort, future capacity, connectivity with the surrounding neighbourhood, and accessibility for variously 'abled' people. Give campus roads and pathways names and signage.

\section{REFERENCES}

Alcock I, White M.P., Wheeler B.W., Fleming L.E., Depledge M.H., 2014: Longitudinal Effects on Mental Health of Moving to Greener and Less Green Urban Areas. Environmental Science \& Technology 48: 1247-1255.

Allan H.H., 1961: Flora of New Zealand. Volume 1 Indigenous Tracheophyta, Psilopsida, Lycopsida, Filicopsida, Gymnospermae, Dicotyledones. R.E. Owen, Government Printer. Wellington, New Zealand.

Anon, 2013: Unitech's arboretum. Advance Spring 8-11. Journal produced by Unitech Institute of Technology. Accessed online at http://www.unitec.ac.nz/research/advance-magazine on 10/01/2016.

Anon, 2015: The tree project. Go Gardening Winter 26-27. The Magazine of the Nursery and Garden Industry of New Zealand.

Ashman T., Knight T.M., Steets J.A., Amarasekare P., Burd M., Campbell D.R., Michele R. Dudash M.R., Johnston M.O., Mazer S.J., Mitchell R.J., Morgan M.T. and William G. Wilson W.G., 2004: Pollen limitation of plant reproduction: ecological and evolutionary causes and consequences. Concepts \& Synthesis: Emphasizing New Ideas To Stimulate Research In Ecology 85(9): 2408-2421.

Baker S.E. and Edwards R., 2014: How many qualitative interviews is enough? Expert voices and early career reflections on sampling and cases in qualitative research. National 
Centre for Research Methods Review Paper. Accessed online at http://eprints.ncrm.ac.uk/2273/4/how_many_interviews.pdf 28/07/2016.

Barrowman R., 1999: Victoria University of Wellington 1899-1999: a history. Victoria University Press. Wellington.

Bell R., 1996: Seed dispersal by kererū (Hemiphaga novaeseelandiae) at Wenderholme Regional Park. MSc Thesis. University of Auckland.

Bellingham P.J., Stewart G.H. and Allen R.B., 1999: Tree species richness and turnover throughout New Zealand forests. Journal of Vegetation Science 10: 825-832.

Berto R., 2005: Exposure to restorative environments helps restore attentional capacity. Journal of Environmental Psychology 25: 249-259.

Bishop J., Bertrand N., Evison W., Gilbert S., Grigg A., Hwang L., Kallesoe M., Vakrou A., van der Lugt C. and Vorhies F., 2010: TEEB - The economics of ecosystems and biodiversity report for business - executive summary 2010. The United Nations Environmental Programme.

Boudial I., Baudoin E., Sanguin H., Beddiar A., Thoiulouse J., Galiana A., Prin Y., Le Roux C., Lebrun M and Dupponois R., 2013: The exotic legume tree species, Acacia mearnsii, alters microbial soil functionalities and the early development of a native tree species, Quercus suber, in North Africa. Soil Biology and Chemistry 65: 182-179.

Braun V. and Clarke V., 2006: Using thematic analysis in psychology. Qualitative Research in Psychology 3: 77-101.

Buchanan J., 1875: Notes on the Colonial Botanic Gardens, Wellington and its flora. A facsimile of a paper that was read to the Wellington Philosophical Society. (4 October 1875). Accessed online at www.nzpcn.org. 24 February 2016.

Burns K.C., 2007: Is tree diversity different in the Southern Hemisphere? Journal of Vegetation Science 18: 307-312.

Campbell K.L. 2006: A study of home ranges, movements, diet and habitat use of kererū (Hemiphaga novaeseelandiae) in the southeastern sector of Banks Peninsula, New Zealand. MSc Thesis. Lincoln University. 
Campbell K.L. 2006: A study of home ranges, movements, diet and habitat use of kererū (Hemiphaga novaeseelandiae) in the southeastern sector of Banks Peninsula, New Zealand. MSc Thesis. Lincoln University.

Charles K.E., 2013: Urban human-wildlife conflict: North Island kākā (Nestor meridionalis septentrionalis) in Wellington City. MSc Thesis. Victoria University of Wellington.

Charles K.E., 2013: Urban human-wildlife conflict: North Island kākā (Nestor meridionalis septentrionalis) in Wellington City. MSc Thesis. Victoria University of Wellington.

Chiarucci A., Bacaro G. and Scheiner S.M., 2011: Old and new challenges in using species diversity for assessing biodiversity. Philosophical Transactions of the Royal Society B 366: 2436-2437.

Cook W., 1992: Letter from John Ward to Captain William Mein Smith. Background Report 3, European History. Wellington Town Belt Management Plan Review. Wellington City Council.

Cook W., No Date: Native forest remnants in the Wellington Botanic Garden. Report produced for Friends of Wellington Botanic Garden. Accessed online at http://www.friendswbg.org.nz/nomenu/Native\%20Forest\%20Remnants\%20in\%20the \%20Wellington\%20Botanic\%20Garden.pdf 9/01/2015.

Cooke N.J., 1994: Varieties of knowledge elicitation techniques. International Journal of Human - Computer Studies. 41(6): 801-849.

Corner J., 2005: Botanical ubanism: a new project for the botanical garden at the University of Puerto Rico. Studies in the history of gardens and Designed Landscapes: An International Quarterly 25(2): 123-143.

Cronk Q., 2016: Plant extinctions take time. Science 353(6298): 446-447.

Dawson J. and Lucas R., 2011: New Zealand's native trees. Craig Potton Publishing. Nelson, New Zealand.

de Lange P.J., 2006: Myoporum aff. insulare. Fact Sheet prepared for the New Zealand Plant Conservation Network. Accessed online at http://www.nzpcn.org.nz/flora_details.aspx?ID=3210 28/03/2016. 
de Lange P., 2014: A revision of the New Zealand Kunzea ericoides (Myrtaceae) complex. PhytoKeys 40: 1-185.

de Lange P.J., Rolfe J.R., Champion P.D., Courtney S.P., Heenan P.B., Barkla J.W., Cameron E.K., Norton D.A. and Hitchmough R.A., 2013: Conservation status of New Zealand indigenous vascular plants, 2012. New Zealand Threat Classification Series 3. Department of Conservation.

Department of Conservation: Karobusting. Accessed online at http://www.doc.govt.nz/getinvolved/volunteer/in-your-region/wellington-kapiti/matiu-somes-island/ 7 April 2016.

Dolesh R.J., 2014: Why parks are essential for greener healthier cities: A conversation with urban parks and planning expert Kaid Benfield. Parks and Recreation 49(5): 54-57.

Eagle A., 2006: Eagle's complete trees and shrubs of New Zealand. Te Papa Press. Wellington.

Elmqvist T., Fragkias M., Goodness J., Güneralp B., Marcotullio P.J., McDonald R.I., Parnell S., Schewenius M., Sendstad M., Seto K.C. and Cathy Wilkinson ., Eds. 2013: Urbanization, Biodiversity and Ecosystem Services: Challenges and Opportunities. Springer. Dordrecht.

Fang J., Wu C. and Cheng L., 2011: Comparison of urban residents' use and perceptions of urban opens spaces in China, Canada and USA. Conference paper presented to the 47th ISOCARP (International Society of City and Regional Planners) Congress, Wuhan, China.

Food and Agriculture Organisation of the United Nations. 2010: Global forest resources assessment 2010. Rome.

Gaston K.J., 2010: Urbanisation. In Ed. Gaston K.J., Urban Ecology. Cambridge University Press. Cambridge.

Gentry A.H. 1988: Changes in plant community diversity and floristic composition on environmental and geographic gradients. Annals of the Missouri Botanical Garden 75: 1-34. 
Gillison A., Bignell D., Brewer K., Fernandes E., Jones D., Sheil D., May P., Watt A., Constantino R., Couto E., Hairiah K., Jepson P., Kartono A., Maryanto I., Neto G., Noordwijk M., Silveira E., Susilo F., Vosti S., Nunes P., 2013: Plant functional types and traits as biodiversity indicators for tropical forests: two biogeographically separated case studies including birds, mammals and termites. Biodiversity and Conservation 22(9): 1909-1930

Greater Wellington Regional Council, 2009: Pest plants of the Wellington region. GW/BIOG-09/67.

Gundersen V.S. and Frivold L.H., 2008: Public preferences for forest structures: a review of quantitative surveys from Finland, Norway and Sweden. Urban forestry and urban greening 7: 241-258.

Hadavi S., Kaplan R. and Hunter M.C., 2015: Environmental affordances: a practical approach for design of nearby outdoor settings in urban residential areas. Landscape and Urban Planning 134: 19-32.

Hay R. and Beckett K.A., Eds., 1978: Reader's Digest encyclopaedia of garden plants and flowers. The Reader's Digest Association. London.

Holick M. and Jenkins M., Eds. 2004: The UV advantage. I Books.

Home R., Hunziker M and Bauer N., 2012: Psychosocial outcomes as motivations for visiting nearby urban green spaces. Leisure Sciences 34(4): 350-365.

Hora B., Ed. 1981: The Oxford encyclopaedia of trees of the world. Oxford University Press. Oxford.

Horwitz P. and Kretsch C., 2015: Contribution of biodiversity and green spaces to mental and physical fitness, and cultural dimensions of health. In Lead coordinating authors: Romanelli C., Cooper D., Campbell-Lendrum D., Maiero M., Karesh W.B., Hunter D. and Golden C.D. Connecting global priorities : biodiversity and human health: a state of knowledge review. World Health Organisation and Secretariat of the Convention on Biological Diversity. Accessed online at https://www.cbd.int/health/SOKbiodiversity-en.pdf on 20/02/2016. 
Houdet J., Trommetter M. and Weber J., 2012: Understanding changes in business strategies regarding biodiversity and ecosystem services. Ecological Economics 73: 37-46

Hurlbert S.H., 1971: The non-concept of species diversity: A critique and alternative parameters. Ecology 52: 577-586.

Jenks G.F., 1967: The Data Model Concept in Statistical Mapping. International Yearbook of Cartography 7: 186-190

Jim C.Y. and Chen W.Y., 2006: Perception and attitude of residents toward urban green spaces in Guangzhou (China). Environmental Management 38(3): 338-349.

Jim C.Y. and Liu H.T., 2001: Species diversity of three major urban forest types in Guangzhou City, China. Forest Ecology and Management 146: 99-114

Jorgensen, A. and Anthopoulou, A. 2007: Enjoyment and fear in urban woodlands - Does age make a difference? Urban Forestry \& Urban Greening, 6(4): 267-278

Kabisch N., 2015: Ecosystem service implementation and governance challenges in urban green space planning - the case of Berlin, Germany. Land Use Policy 43: 537-567

Kaplan R., 1993: The role of nature in the context of the workplace. Landscape and Urban Planning 26: 193-201.

Kaplan R., 2005: Employee's reactions to nearby nature at their workplace: The wild and the tame. Landscape and Urban Planning 82: 17-24.

Kaplan S. 1995: The restorative benefits of nature: toward an integrative framework. Journal of Environmental Psychology 15: 169-182.

Kardan O., Gozdyra P., Misic B., Moola F., Palmer L.J., Paus T. and Berman M.G., 2015: Neighborhood greenspace and health in a large urban centre. Scientific Reports 5. 2015/07/09/online

Kelly D., Ladley J.J., Robertson A.W., Anderson S.H., Wotton D.M. and Wiser S.K., 2010: Mutualisms in the wreckage of an avifauna: the status of bird pollination and fruit dispersal in New Zealand. New Zealand Journal of Ecology 34(1): 66-85. 
Kent M., 2011: Vegetation description and data analysis: A practical approach. eBook, 2nd edition. John Wiley and Sons. New Jersey.

Krenichyn K., 2006: The only place to go and be in the city: women talk about exercise, being outdoors, and the meanings of a large urban park. Health and Place 12: 631643.

Kühn I., Brandl R. and Klotz S., 2004: The flora of German cities is naturally species rich. Evolutionary Ecology Research. 6: 749-764.

Leach H., 2000: Cultivating myths: fiction fact and fashion in garden history. Godwit. Auckland.

Lo A.Y.H. and Jim C.Y., 2012: Citizen attitude and expectation towards greenspace provision in compact urban milieu. Land Use Policy 29: 577-586.

Magurran A.E., 1988: Ecological diversity and its measurement. Princeton University Press. Princeton NY.

Manning A.D., Fischer J. and Lindenmayer D.B., 2006: Scattered trees are keystone structures - implications for conservation. Biological Conservation 132:311-321.

Mason R.S , Sequeira V.B. and Gordon-Thomson C., 2011: Vitamin D: the light side of sunshine. European Journal of Clinical Nutrition 65: 986-993.

Massey University arboretum and botanic gardens: accessed online at https://www.bgci.org/garden.php?id=889 on 10 April 2016

Matsuoka R.H. and Kaplan R., 2008: People needs in the urban landscape: Analysis of Landscape and Urban Planning contributions. Landscape and Urban Planning 84: 719.

Meurk C.D. 2003: Cities are cultural and ecological keys to biodiverse futures. The 2003 Banks Memorial Lecture. Presented to the Royal New Zealand Institute of Horticulture and reproduced in New Zealand Garden Journal 6(2): 3-10. 
Meurk C.D., Blaschke P.M. and Simcock R., 2013: Ecosystem services in New Zealand cities. In Dymond J.R. ed. Ecosystem services in New Zealand: conditions and trends. Manaaki Whenua Press. Lincoln, New Zealand.

McDonald R.I., Marcotullio P.J. and Güneralp B., 2013: Urbanization and Global Trends in Biodiversity and Ecosystem Services. In Eds. Elmqvist T., Fragkias M., Goodness J., Güneralp B., Marcotullio P.J., McDonald R.I., Parnell S., Schewenius M., Sendstad M., Seto K.C. and Cathy Wilkinson. Urbanization, Biodiversity and Ecosystem Services: Challenges and Opportunities. Springer. Dordrecht.

McKinney M.L., 2010: Urban futures. In Ed. Gasyon K.J., Urban Ecology. Cambridge University Press. Cambridge.

Millar Gault S. and Kalmbacher G., 1976: The color dictionary of shrubs. Crown Publishers Inc. in collaboration with The Royal Horticultural Society. New York.

Mitchell R. and Popham F., 2008: Effect of exposure to natural environment on health inequalities: an observational population study. Lancet 372: 1655-1660.

Modi N.R. and Dudani S.N., 2013: Biodiversity conservation through urban green spaces: a case study of Gujarat University campus in Ahmaedabad. International Journal of Conservation Science 4(2): 189-196.

Morgenroth J., Östberg J., van den Bosch C.K., Nielsen A.B., Hauer R., Sjöman H., Chen W. and Jansson M., 2016: Urban tree diversity-Taking stock and looking ahead. Urban Forestry \& Urban Greening 15: 1-5.

Müller N., Ignatieva M., Nilon C.H., Werner P. and Zippere W.C., 2013: Patterns and trends in urban biodiversity and landscape design. In Eds. Elmqvist T., Fragkias M., Goodness J., Güneralp B., Marcotullio P.J., McDonald R.I., Parnell S., Schewenius M., Sendstad M., Seto K.C., and Wilkinson C. Urbanization, Biodiversity and Ecosystem Services: Challenges and Opportunities A Global Assessment. A part of the cities and Biodiversity outlook project. Springer. Dordrecht.

Muratet A., Pellegrini P., Dufour A., Arrif T. and Chiron F., 2015: Perception and knowledge of plant diversity among urban park users. Landscape and Urban Planning 137: 95106. 
Muthulingam U. and Thangavel S., 2012: Density, diversity and richness of woody plants in urban green spaces: a case study in Chennai metropolitan city. Urban Forestry and Urban Greening 11: 450-459.

Myers S., 1987: Native forest remnants in Wellington's Botanic Gardens. Wellington Botanical Society Bulletin 43: 32-40

Nagendra H. and Gopal D., 2010: Street trees in Bangalore: density, diversity, composition and distribution. Urban forestry and urban greening 9: 129-137.

Nagendra H. and Gopal D., 2011: Tree diversity, distribution, history and change in urban parks: studies in Bangalore, India. Urban ecosystems 14: 211-223.

NatureWatch: Life in the Wellington Botanic Garden. Accessed online at http://naturewatch.org.nz/projects/life-in-the-wellington-botanic-garden 3/03/2016.

Nielsen A.B., Östburg J. and Delshammer T., 2014: Review of urban tree inventory methods used to collect data at single tree level. Arboriculture and Urban Forestry 40(2): 96111.

Oppezzo M and Schwartz D.L., 2014: Give your ideas some legs: the positive effect of walking on creative thinking. Journal of Experimental Psychology 40(4): 1142-1152.

Ordonez C. and Duinker P.N., Ecological integrity in urban forests. Urban Ecosystems $15: 863-877$.

Orr S., Paskins J. and Chaytor S., 2014: Valuing urban green space: challenges and opportunities. University College of London Policy Briefing Paper. Developed by the UCL Public Policy Department and published online at https://www.ucl.ac.uk/public-policy/public-policybriefings/urban_green_spaces_briefing_FINAL.pdf. Accessed 10 April 2016

Park G. 2006: Theatre country: essays on landscape and whenua. Victoria University Press. Wellington.

Perrie L., Russell P., Ogle C., Mitcalfe B., Horne C., Burton E., Rolfe J. and Elliot R., 2011: Non-local indigenous New Zealand vascular plants self-propagating in Wellington. Wellington Botanical Society Bulletin 53: 23-47. 
Poole R.W., 1974: An introduction to quantitative ecology. McGraw-Hill. New York.

Popay I., Champion P. and James T., 2010: An illustrated guide to common weeds of New Zealand. Third edition. New Zealand Plant Protection Society. Christchurch.

Porter E.E., Forschner B.R. and Blair R.B., 2001: Woody vegetation and canopy fragmentation along a forest to urban gradient. Journal of Urban Ecosystems 5: 131151.

Real L.A. and Levin S.A., 1991: The role of theory in the rise of modern ecology. In Ed.s Real L.A. and Brown J.H. Foundations of ecology: classic papers with commentaries. The University of Chicago Press. Chicago.

Rogers K., Sacre K., Goodenough J. and Doick K., 2015: Valuing London's Urban forest: results of the London i-Tree Eco Project. Treeconomics London. London. Accessed online at http://www.forestry.gov.uk/pdf/2890-Forest_Report_Pages.pdf/\$FILE/2890Forest_Report_Pages.pdf 10/4/2016.

Salmon J.T., 1999: The trees in New Zealand: exotic trees, the broadleaves. Reed Publishing New Zealand Ltd. Auckland.

Salmon J.T., 1999: The trees in New Zealand: exotic trees, the conifers. Reed Publishing New Zealand Ltd. Auckland.

Sandifer P.A., Sutton-Grier A.E. and Ward B.P., 2015: Exploring connections among nature, biodiversity, ecosystem services, and human health and well-being: Opportunities to enhance health and biodiversity conservation. Ecosystem Services 12: 1-15.

Sarukhán J., and Whyte A., Eds. and the Millenium Assessment Board of Editors. 2005: Ecosystems and human well-being: synthesis. A report of the Millennium Ecosystem Assessment. Island Press. Washington D.C.

Serret H., Raymond R., Foltête J.C., Clergeau P., Simon L. and Machon N., 2014: Potential contributions of green spaces at business sites to the ecological network in an urban agglomeration: the case of the Ile-de-France region, France. Landscape and Urban Planning 131: 27-35. 
Simpson P., 2005: Pōhutukawa and rātā: New Zealand's iron-hearted trees. Te Papa Press. Wellington.

Snep R., van Ehrland E. and Opdam P., 2009: Enhancing biodiversity at business sites: what are the options, and which of these do stakeholders prefer? Landscape and Urbna Planning 91: 26-35.

Snep R., Wallis de Vries M.F. and Opdam P., 2011: Conservation where people work: a role for business districts and industrial areas in enhancing endangered butterfly populations? Landscape and Urban Planning 103: 94-101.

Stohlgren T.J., 2007: Measuring plant diversity: lessons from the field. Oxford University Press. New York.

Sudha P and Ravindranath N.H., 2000: A study of Bangalore urban forest. Landscape and Urban Planning 471: 47-63

Thomsen P., Bühler O. and Kristoffersen P., 2016: Diversity of street tree populations in larger Danish municipalities. Urban Forestry \& Urban Greening 15: 200-210

Thorsen M.J., Dickinson K.J.M. and Seddon P.J., 2009: Seed dispersal systems in the New Zealand flora. Perspectives in Plant Ecology, Evolution and Systematics 11: 285-309

Tornhammar P., Ueda P., Hult M., Simila H., Eyles D. and Norman M., 2014: Season of birth, neonatal vitamin D status, and cardiovascular disease risk at $35 \mathrm{y}$ of age: a cohort study from Sweden. The American Journal of Clinical Nutrition 99(3): 472478.

Tzoulas K., Korpela K., Venn S., Yli-Pelkonen V., Kazmierczak A., Niemela J and James P., 2007: Promoting ecosystem and human health in urban areas using green infrastructure: a literature review. Landscape and Urban Planning 81:167-178.

Ulrich R.S., Simons R.F., Losito B.D., Fiorito E., Miles M.A. and Zelson M., 1991: Stress recovery during exposure to natural and urban environments. Journal of Environmental Psychology 11:201-230.

Unitech arboretum: accessed online at http://www.unitec.ac.nz/trees/ on 10 April 2016) 
United Nations 2014: World's population increasingly urban with more than half living in urban areas. Article accessed online at http://www.un.org/ en/development/desa/news/population/world-urbanization-prospects-2014.html 12 April 2013.

Van Kluenen M., Dawson W., Essl F., Pergl J., Winter M., Weber E., Kreft H., Weigelt P., Kartesz J., Nishino M., Antonova L.A., Barcelona J.F., Cabezas F.J., Cárdenas D., Cárdenas-Toro J., Castaño N., Chacón E., Chatelaine C., Ebel A.L., Figueiredo E., Duentes N., Groom Q.J., Henderson L., Inderjit, Kupriyanov A., Masciadri S., Meerman J., Morozova O., Moser D., Nickrent D.L., Patzelt A., Pelser P.B., Baptiste M.P., Poopath M., Schulze M., Seebens H., Shu W., Thomas J., Velayos M., Wieringa J.J. and Pysěk P., 2015: Global exchange and accumulation of non-native plants. Nature 525(7567): 100-103.

Victoria University of Wellington, no date: Environmental policy: Campus Services Policy Group. Un-published document.

VUW web post 1 July 2015: https://www.victoria.ac.nz/news/2015/07/top-scholar-andsenior-leader-appointed-provost-at-victoria-university Accessed on 9/10/2015.

Wan C. and Shen G.Q., 2015 Salient attributes of urban green spaces in high density cities. Habitat International 49: 92-99.

Wellington Botanical Society 2007: Un-published plant checklist of indigenous plant species at Waimapihi Reserve, Aro Valley, Wellington.

Wellington City Council 2013: Wellington Town Belt Management Plan - June 2013.

Wellington City Council, 2015: Our natural capital: Wellington's biodiversity strategy and action plan 2015 .

WHO 2015: Connecting global priorities: biodiversity and human health. World Health Organisation and Secretariat of the Convention on Biological Diversity. Accessed online at http://www.who.int/globalchange/publications/biodiversity-humanhealth/en/ on 12 April 2016. 
Wilson H. and Galloway T., 1993: Small-leaved shrubs of New Zealand. Manuka Press. Christchurch.

Wu C., McNeely E., Cendeno-Laurent J.G., Pan W., Adamkiewicz G., Dominici F., Lung S.C., Su H. and Spengler J.D., 2014: Linking school performance in Massachusetts elementary schools with the "greenness" of school surroundings using remote sensing. Plos One 9(10).

Zhou X. and Rana M.M.P., 2012: Social benefits of urban green space. Management of Environmental Quality 23(2): 173-189. 


\section{ALL TREE SPECIES RECORDED ON THE KELBURN CAMPUS BETWEEN 1961-2015}

Nomenclature is based on the New Zealand Plant Conservation Network (www.nzpcn.org), the Integrated Taxonomic Information System (itis.gov) a partnership of United States, Canadian and Mexican Agencies, the Electronic Plant Information Centre, Kew Gardens (epic.kew.org/index.htm), and the Australian Plant Name Index (anbg.gov.au). The naming for Kunzea spp. follows the pre de Lange (2014) revision.

References for the checklists are:

Short J., Date unknown: Victoria University of Wellington Plants growing on campus. A series of lists compiled by Mr Joe Short during his term as Grounds Superintendent 19611982. Held by the Manager of Information and Records Management, Victoria University of Wellington awaiting accession.

Orchard M. and Smith R. 1990: Victoria University plant species list. Held by the Manager of Information and Records Management, Victoria University of Wellington awaiting accession.

\begin{tabular}{|l|l|c|c|c|}
\hline SCIENTIFIC NAME & COMMON NAME & $\begin{array}{c}\text { VUW } \\
\mathbf{6 1 - 8 2}\end{array}$ & $\begin{array}{c}\text { VUW } \\
\mathbf{1 9 9 0}\end{array}$ & $\begin{array}{c}\text { VUW } \\
\mathbf{1 4 - 1 5}\end{array}$ \\
\hline INDIGENOUS GYMNOSPERMS & & & & \\
\hline Agathis australis & & & & \\
\hline Dacrycarpus dacrydioides & kauri & & $\checkmark$ & $\checkmark$ \\
\hline Dacrydium cupressinum & kahikatea & & $\checkmark$ & $\checkmark$ \\
\hline Halocarpus biformis & rimu & $\checkmark$ & $\checkmark$ & \\
\hline Libocedrus plumosa & pink pine, yellow pine & $\checkmark$ & & \\
\hline Phyllocladus trichomanoides & & & $\checkmark$ & $\checkmark$ \\
\hline Podocarpus laetus & tānekaha, celery pine & & $\checkmark$ & $\checkmark$ \\
\hline Podocarpus totara var. totara & mountain totara & & $\checkmark$ & \\
\hline Prumnopitys ferruginea & tōtara & $\checkmark$ & $\checkmark$ & $\checkmark$ \\
\hline Prumnopitys taxifolia & miro & & $\checkmark$ & $\checkmark$ \\
\hline & mataī & & & $\checkmark$ \\
\hline MONOCOT TREES & & & & \\
\hline Cordyline australis & & & & \\
\hline
\end{tabular}




\begin{tabular}{|c|c|c|c|c|}
\hline SCIENTIFIC NAME & COMMON NAME & $\begin{array}{l}\text { VUW } \\
61-82\end{array}$ & $\begin{array}{l}\text { VUW } \\
1990\end{array}$ & $\begin{array}{l}\text { VUW } \\
14-15\end{array}$ \\
\hline Cordyline banksii & tĩ ngahere, cabbage tree & & $\checkmark$ & \\
\hline Cordyline indivisa & tōī, mountain cabbage tree & $\checkmark$ & & \\
\hline Cordyline obtecta & Three Kings cabbage tree & $\checkmark$ & $\checkmark$ & \\
\hline Rhopalostylus sapida & nīkau & $\checkmark$ & $\checkmark$ & $\checkmark$ \\
\hline \multicolumn{5}{|c|}{ DICOT TREES AND SHRUBS } \\
\hline Ackama rosifolia & & & & $\checkmark$ \\
\hline Alectryon excelsus & tītoki & & & $\checkmark$ \\
\hline \multicolumn{5}{|l|}{ Alseuosmia macrophylla } \\
\hline Aristotelia serrata & makomako, wineberry & & $\checkmark$ & $\checkmark$ \\
\hline Ascarina lucida var. lucida & hutu & & $\checkmark$ & \\
\hline Brachyglottis elaeagnifolia & & $\bar{\checkmark}$ & & \\
\hline Brachyglottis greyi & & $\checkmark$ & $\checkmark$ & \\
\hline Brachyglottis monroi & & $\checkmark$ & $\checkmark$ & \\
\hline Brachyglottis repanda & rangiora & $\checkmark$ & $\checkmark$ & $\checkmark$ \\
\hline Carmichaelia arborea & & & $\checkmark$ & \\
\hline Carmichaelia australis & common broom & & $\checkmark$ & \\
\hline Carmichaelia kirkii & climbing broom & & $\checkmark$ & \\
\hline Carmichaelia muritai & coastal tree broom & & $\checkmark$ & \\
\hline Carmichaelia nana & dwarf broom & & $\checkmark$ & \\
\hline Carmichaelia oderata & scented broom & & $\checkmark$ & \\
\hline Carmichaelia sp. & & & & $\checkmark$ \\
\hline Carmichaelia stevonsonii & weeping tree broom & & $\checkmark$ & \\
\hline Carmichaelia williamsii & giant-flowered broom & & $\checkmark$ & \\
\hline Carpodetus serratus & putaputawētā, marbleleaf & & $\checkmark$ & $\checkmark$ \\
\hline Clianthus puniceus & kākā beak & $\checkmark$ & $\checkmark$ & \\
\hline Coprosma arborea & māmāngi & & $\checkmark$ & \\
\hline Coprosma foetidissima & stinkwood & & & $\checkmark$ \\
\hline Coprosma grandifolia & kanono & & $\checkmark$ & $\checkmark$ \\
\hline $\begin{array}{l}\text { Coprosma macrocarpa subs } \\
\text { macrocarpa }\end{array}$ & & & & $\checkmark$ \\
\hline Coprosma microcarpa & & & & $\checkmark$ \\
\hline Coprosma parviflora & & $\checkmark$ & & $\checkmark$ \\
\hline $\begin{array}{l}\text { Coprosma propinqua var. } \\
\text { propinqua }\end{array}$ & mingimingi & & $\checkmark$ & $\checkmark$ \\
\hline \multicolumn{5}{|c|}{ Coprosma propinqua $\times$ robusta } \\
\hline Coprosma repens & taupata & $\checkmark$ & $\checkmark$ & $\checkmark$ \\
\hline $\begin{array}{l}\text { Coprosma repens aff. Poor } \\
\text { Knights }\end{array}$ & & & & $\checkmark$ \\
\hline Coprosma rhamnoides & & & & $\checkmark$ \\
\hline
\end{tabular}




\begin{tabular}{|c|c|c|c|c|}
\hline SCIENTIFIC NAME & COMMON NAME & $\begin{array}{l}\text { VUW } \\
61-82\end{array}$ & $\begin{array}{l}\text { VUW } \\
1990\end{array}$ & $\begin{array}{l}\text { VUW } \\
14-15\end{array}$ \\
\hline Coprosma robusta & karamū & & $\bar{\checkmark}$ & $\checkmark$ \\
\hline Coprosma robusta $\mathrm{x}$ propinqua & & & & $\checkmark$ \\
\hline Coprosma sp. & & & $\checkmark$ & $\checkmark$ \\
\hline Coprosma virescens & & & & $\checkmark$ \\
\hline Coriaria pottsiana & & & $\checkmark$ & \\
\hline Corokia buddleioides & korokio & $\checkmark$ & $\checkmark$ & $\checkmark$ \\
\hline Corokia cotoneaster & korokio & $\bar{\checkmark}$ & $\checkmark$ & $\checkmark$ \\
\hline Corokia macrocarpa & korokio & & $\checkmark$ & $\checkmark$ \\
\hline Corynocarpus laevigatus & karaka & & $\checkmark$ & $\checkmark$ \\
\hline Dodonaea viscosa & akeake & $\checkmark$ & $\checkmark$ & $\checkmark$ \\
\hline Elaeocarpis dentatus var. dentatus & hīnau & & & $\checkmark$ \\
\hline Entelia arborescens & whau & $\checkmark$ & $\checkmark$ & $\checkmark$ \\
\hline Fuscospora solandri & black beech & & $\checkmark$ & $\checkmark$ \\
\hline Fuscospora truncata & hard beech & & & $\checkmark$ \\
\hline $\begin{array}{l}\text { Geniostoma rupestre var. } \\
\text { ligustrifolium }\end{array}$ & hangehange & & & $\checkmark$ \\
\hline Griselinia lucida & puka & $\checkmark$ & $\checkmark$ & 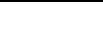 \\
\hline Griselinia littoralis & papauma, broadleaf & $\checkmark$ & $\checkmark$ & $\checkmark$ \\
\hline Hedycarya arborea & porokaiwhiri, pigeonwood & & & $\checkmark$ \\
\hline Hoheria populnea & houhere, lacebark & $\checkmark$ & $\checkmark$ & $\checkmark$ \\
\hline Hoheria sexstylosa & houhere, lacebark & & $\checkmark$ & $\checkmark$ \\
\hline Knightia excelsa & rewarewa & $\checkmark$ & $\checkmark$ & $\checkmark$ \\
\hline Kunzea ericioides & kanuka & & $\checkmark$ & $\checkmark$ \\
\hline Leionema nudum & phebalium & $\checkmark$ & 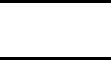 & \\
\hline Leptospermum scoparium & manuka & $\checkmark$ & $\checkmark$ & $\checkmark$ \\
\hline Leucopogon fraseri & pātōtara & & $\checkmark$ & \\
\hline Lophomyrtus bullata & ramarama & & $\checkmark$ & $\checkmark$ \\
\hline Lophomyrtus obcordatum & & & $\checkmark$ & $\checkmark$ \\
\hline Lophomyrtus cv. & & $\checkmark$ & $\checkmark$ & \\
\hline Lophonzia menziesii & silver beech & & $\checkmark$ & $\checkmark$ \\
\hline Melicope ternata & whārangi & $\checkmark$ & & $\checkmark$ \\
\hline Melicytus chathamicus & & & & $\checkmark$ \\
\hline Melicytus crassifolius & & & & $\checkmark$ \\
\hline Melicytus lanceolatus & & & & $\checkmark$ \\
\hline Melicytus macrophyllus & & & & $\checkmark$ \\
\hline Melicytus novae-zelandiae & & & & $\checkmark$ \\
\hline Melicytus obovatus & & & & $\checkmark$ \\
\hline $\begin{array}{l}\text { Melicytus ramiflorus subsp. } \\
\text { ramiflorus }\end{array}$ & māhoe, whiteywood & $\checkmark$ & $\checkmark$ & $\checkmark$ \\
\hline
\end{tabular}




\begin{tabular}{|c|c|c|c|c|}
\hline SCIENTIFIC NAME & COMMON NAME & $\begin{array}{l}\text { VUW } \\
61-82\end{array}$ & $\begin{array}{l}\text { VUW } \\
1990\end{array}$ & $\begin{array}{l}\text { VUW } \\
14-15\end{array}$ \\
\hline Meryta sinclairii & pūka & $\checkmark$ & $\checkmark$ & $\checkmark$ \\
\hline Metrosideros excelsa & pohutukawa & $\checkmark$ & $\checkmark$ & $\checkmark$ \\
\hline $\begin{array}{l}\text { Metrosideros excelsa } \mathrm{x} \\
\text { kermadecensis }\end{array}$ & & & & $\checkmark$ \\
\hline Metrosideros escelsa $\times$ robusta & & & & $\checkmark$ \\
\hline Metrosideros kermadecensis & & $\checkmark$ & $\checkmark$ & $\checkmark$ \\
\hline Metrosideros robusta & rātā & & $\checkmark$ & $\checkmark$ \\
\hline Metrosideros umbellata & & & $\checkmark$ & $\checkmark$ \\
\hline Myoporum laetum & ngaio & & $\checkmark$ & $\checkmark$ \\
\hline Myoporun semotum & & & & $\checkmark$ \\
\hline Myrsine australis & māpou & & & $\checkmark$ \\
\hline Myrsine divaricata & weeping māpou & & $\checkmark$ & \\
\hline Myrsine salicina & toro & & . & $\checkmark$ \\
\hline Muehlenbeckia astonii & & & & $\checkmark$ \\
\hline Nestegis lanceolata & maire rauriki & & $\checkmark$ & $\checkmark$ \\
\hline Olearia albida & & $\checkmark$ & $\checkmark$ & \\
\hline Olearia arborescens & & & $\checkmark$ & \\
\hline Olearia avicenniifolia & & & $\checkmark$ & $\checkmark$ \\
\hline Olearia cheesemanii & streamside tree daisy & $\checkmark$ & $\checkmark$ & \\
\hline Olearia coriacea & & & $\checkmark$ & \\
\hline Olearia ilicifolia & mountain holly & $\checkmark$ & & \\
\hline Olearia lineata & & & & $\checkmark$ \\
\hline Olearia nummulariifolia & & & $\checkmark$ & \\
\hline Olearia pachyphylla & thick-leaved tree daisy & & $\checkmark$ & \\
\hline Olearia paniculata & akiraho, golden akeake & & $\checkmark$ & $\checkmark$ \\
\hline Olearia solandri & & & & $\checkmark$ \\
\hline Olearia sp. & & & & $\checkmark$ \\
\hline Olearia traversiorum & Chathan Island tree daisy & & $\checkmark$ & \\
\hline Ozothamnus leptophylla & tauhinu & $\checkmark$ & $\checkmark$ & \\
\hline Pennantia corymbosa & kaikōmako & & & $\checkmark$ \\
\hline Piper excelsum subsp. excelsum & kawakawa & $\checkmark$ & $\checkmark$ & $\checkmark$ \\
\hline $\begin{array}{l}\text { Piper excelsum subsp. } \\
\text { psittacorum }\end{array}$ & kawakawa & & $\checkmark$ & $\checkmark$ \\
\hline Pisonia brunoniana & parapara & $\checkmark$ & & \\
\hline Pittosporum colensoi & & $\checkmark$ & & \\
\hline Pittosporum cornifolium & tāwhiri karo & $\checkmark$ & & $\checkmark$ \\
\hline Pittosporum crassifolium & & $\checkmark$ & $\checkmark$ & $\checkmark$ \\
\hline Pittosporum dallii & & $\checkmark$ & & \\
\hline Pittosporum eugenioides & tarata, lemonwood & $\checkmark$ & $\checkmark$ & $\checkmark$ \\
\hline Pittosporum obcordatum & & & & $\checkmark$ \\
\hline
\end{tabular}




\begin{tabular}{|c|c|c|c|c|}
\hline SCIENTIFIC NAME & COMMON NAME & $\begin{array}{l}\text { VUW } \\
61-82\end{array}$ & $\begin{array}{l}\text { VUW } \\
1990\end{array}$ & $\begin{array}{l}\text { VUW } \\
14-15\end{array}$ \\
\hline $\begin{array}{l}\text { Pittosporum pimeleoides subsp. } \\
\text { pimeleoides }\end{array}$ & & & $\checkmark$ & \\
\hline Pittosporum ralphii & karo & $\checkmark$ & $\checkmark$ & $\checkmark$ \\
\hline Pittosporum sp. & & & & $\checkmark$ \\
\hline Pittosporum tenuifolium & kōhūhū & $\checkmark$ & $\checkmark$ & $\checkmark$ \\
\hline Plagianthus divaricatus & salt marsh ribbonwood & & $\checkmark$ & \\
\hline Plagianthus regius subsp. regius & mānatu & $\checkmark$ & $\checkmark$ & \\
\hline Planchonella costata & & & & $\checkmark$ \\
\hline $\begin{array}{l}\text { Pomaderris apetala subsp. } \\
\text { maritima }\end{array}$ & tainui & & $\checkmark$ & $\checkmark$ \\
\hline Pomaderris kumeraho & kūmerahou & & $\checkmark$ & \\
\hline Pouzolzia australis & & & & $\checkmark$ \\
\hline Pseudopanax arboreus & whauwhaupaku, five finger & & $\checkmark$ & $\checkmark$ \\
\hline $\begin{array}{l}\text { Pseudopanax colensoi var. } \\
\text { colensoi }\end{array}$ & & & & $\checkmark$ \\
\hline Pseudopanax crassifolius & horoeka, lancewood & $\checkmark$ & $\checkmark$ & $\checkmark$ \\
\hline $\begin{array}{l}\text { Pseudopanax crassifolius } \mathrm{x} \\
\text { lessonii }\end{array}$ & hybrid pseudopanax & & $\checkmark$ & $\checkmark$ \\
\hline Pseudopanax discolor & & $\checkmark$ & & \\
\hline Pseudopanax ferox & & & $\checkmark$ & $\checkmark$ \\
\hline Pseudopanax laetus & & $\checkmark$ & $\checkmark$ & \\
\hline Pseudopanax lessonii & houpara & $\checkmark$ & & \\
\hline Pseudowintera colorata & mountain horopito & $\checkmark$ & $\checkmark$ & \\
\hline Schefflera digitata & patē & & & $\checkmark$ \\
\hline Sophora microphylla & kōwhai & $\checkmark$ & $\checkmark$ & $\checkmark$ \\
\hline Sophora microphylla $\mathrm{x}$ & & & & $\checkmark$ \\
\hline Sophora molloyi & & & & $\checkmark$ \\
\hline Sophora prostrata & & & $\checkmark$ & \\
\hline Sophora tetraptera & & $\checkmark$ & $\checkmark$ & $\checkmark$ \\
\hline Streblus banksii & tūrepo, large-leaved milk tree & & & $\checkmark$ \\
\hline Streblus heterophyllus & tūrepo, small-leaved milk tree & & & $\checkmark$ \\
\hline Syzygium maire & maire tawake & & & $\checkmark$ \\
\hline Teucridium parvifolium & & & & $\checkmark$ \\
\hline Toronia toru & toru & $\checkmark$ & & \\
\hline Veronica albicans & & & $\checkmark$ & \\
\hline Veronica angustissima & & & $\checkmark$ & \\
\hline Veronica armstrongii & Armstrongs whipcord & & $\checkmark$ & \\
\hline Veronica barkeri & Chatham Island tree hebe & & $\checkmark$ & \\
\hline Veronica breviracemosa & Kermadec koromiko & & $\checkmark$ & \\
\hline Veronica cv. wiri & & & & $\checkmark$ \\
\hline Veronica cupressoides & cypress hebe & & $\checkmark$ & \\
\hline
\end{tabular}




\begin{tabular}{|c|c|c|c|c|}
\hline SCIENTIFIC NAME & COMMON NAME & $\begin{array}{l}\text { VUW } \\
61-82\end{array}$ & $\begin{array}{l}\text { VUW } \\
1990\end{array}$ & $\begin{array}{l}\text { VUW } \\
14-15\end{array}$ \\
\hline Veronica diosmifolia & & & $\checkmark$ & \\
\hline Veronica evenosa & & & $\checkmark$ & \\
\hline Veronica glaucophylla & & & $\checkmark$ & \\
\hline Veronica hulkeana subsp. evestita & & & $\checkmark$ & \\
\hline Veronica ligustrifolia & & & & $\checkmark$ \\
\hline $\begin{array}{l}\text { Veronica macrocarpa var. } \\
\text { latisepala }\end{array}$ & & & $\checkmark$ & \\
\hline $\begin{array}{l}\text { Veronica macrocarpa var. } \\
\text { macrocarpa }\end{array}$ & & & $\checkmark$ & \\
\hline Veronica ligustrifolia & & & $\checkmark$ & $\checkmark$ \\
\hline Veronica ochracea & & & $\checkmark$ & \\
\hline Veronica odora & & & $\checkmark$ & \\
\hline Veronica parviflora & koromiko taranga, tree hebe & & $\checkmark$ & $\checkmark$ \\
\hline Veronica punicea & & & $\checkmark$ & \\
\hline Veronica rakaiensis & & & $\checkmark$ & \\
\hline Veronica salicifolia & & & $\checkmark$ & \\
\hline Veronica sp. & & & & $\checkmark$ \\
\hline Veronica speciosa & & & $\checkmark$ & $\checkmark$ \\
\hline Veronica stricta var. stricta & koromiko & & $\checkmark$ & $\checkmark$ \\
\hline Veronica topiaria & & & $\bar{\checkmark}$ & \\
\hline Veronica townsonii & & & $\checkmark$ & \\
\hline Veronica traversii & & & $\checkmark$ & \\
\hline Veronica truncatula & & & $\checkmark$ & \\
\hline Veronica venustula & & & $\checkmark$ & \\
\hline Vitex lucens & pūriri & $\checkmark$ & $\checkmark$ & $\checkmark$ \\
\hline Weinmannia racemosa & kāmahi & & $\checkmark$ & \\
\hline \multicolumn{5}{|l|}{ FERNS } \\
\hline Cyathea dealbata & ponga & & $\checkmark$ & $\checkmark$ \\
\hline Cyathea medullaris & mamaku & $\checkmark$ & $\checkmark$ & $\checkmark$ \\
\hline Cyathea smithii & kātote, soft tree fern & & $\checkmark$ & \\
\hline Dicksonia squarrosa & whekī & & & $\checkmark$ \\
\hline Dicksonia fibrosa & whekī ponga & & $\checkmark$ & \\
\hline SCIENTIFIC NAME & COMMON NAME & $\begin{array}{l}\text { VUW } \\
61-82\end{array}$ & $\begin{array}{l}\text { VUW } \\
1990\end{array}$ & $\begin{array}{l}\text { VUW } \\
14-15\end{array}$ \\
\hline \multicolumn{5}{|l|}{ INTRODUCED GYMNOSPERMS } \\
\hline Abies sp. & fir & $\checkmark$ & & \\
\hline Cedrus atlantica glauca & blue Atlas cedar & $\checkmark$ & & \\
\hline
\end{tabular}




\begin{tabular}{|c|c|c|c|c|}
\hline SCIENTIFIC NAME & COMMON NAME & $\begin{array}{l}\text { VUW } \\
61-82\end{array}$ & $\begin{array}{l}\text { VUW } \\
1990\end{array}$ & $\begin{array}{l}\text { VUW } \\
14-15\end{array}$ \\
\hline $\begin{array}{l}\text { Chamaecyparis lawsoniana } \\
\text { "Wissel's saguaro" }\end{array}$ & Lawson's cypress & $\checkmark$ & $\checkmark$ & $\checkmark$ \\
\hline Chamaecyparis obtusa & hinoki false cypress & $\checkmark$ & & \\
\hline Cryptomeria japonica & & $\checkmark$ & $\checkmark$ & \\
\hline Cupressus macrocarpa & macrocarpa & $\checkmark$ & $\checkmark$ & $\checkmark$ \\
\hline Cuprocyparis leylandii & Leyland cypress & $\checkmark$ & $\checkmark$ & \\
\hline Ginkgo biloba & & & & $\checkmark$ \\
\hline Juniperus chinensis & Chinese juniper & $\checkmark$ & $\checkmark$ & $\checkmark$ \\
\hline Juniperus communis & & $\checkmark$ & $\checkmark$ & \\
\hline Juniperus sp. & & & $\checkmark$ & \\
\hline Phyllocladus aspleniifolius & Tasmanian celery top pine & & & \\
\hline Pinus patula & Mexican weeping pine & & $\checkmark$ & $\checkmark$ \\
\hline Pinus pinaster & maritime pine & & $\checkmark$ & \\
\hline Pinus radiata & & & $\checkmark$ & $\checkmark$ \\
\hline Pinus sp & & & $\checkmark$ & $\checkmark$ \\
\hline Podocarpus sp. & & & & $\checkmark$ \\
\hline Sequoia sempervirens & & & & $\checkmark$ \\
\hline Thuja plicata & western red cedar & $\checkmark$ & & \\
\hline Thuya occidentalis & white cedar & $\checkmark$ & $\checkmark$ & \\
\hline \multicolumn{5}{|l|}{ MONOCOT TREES } \\
\hline Howea forsteriana & Lord Howe palm & & & $\checkmark$ \\
\hline Beschorneria yuccoides & yucca & $\checkmark$ & $\checkmark$ & \\
\hline \multicolumn{5}{|l|}{ DICOT TREES AND SHRUBS } \\
\hline Abelia $\times$ grandiflora & glossy abelia & & $\checkmark$ & \\
\hline Abutilon sp. & & & $\checkmark$ & \\
\hline Acacia bayleyana & & $\checkmark$ & & \\
\hline Acacia dealbata & silver wattle & $\checkmark$ & & \\
\hline Acacia longifolia & Sydney golden wattle & $\checkmark$ & & \\
\hline Acacia sp. & & & $\checkmark$ & \\
\hline Acca sellowiana & feijoa & & $\checkmark$ & \\
\hline Acer davidii & & $\checkmark$ & 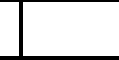 & \\
\hline Acer japonicum & & & $\checkmark$ & \\
\hline Acer palmatum & & $\checkmark$ & $\checkmark$ & \\
\hline Acer pseudoplatanus & sycamore & $\checkmark$ & $\checkmark$ & $\checkmark$ \\
\hline Agonis flexuosa & West Australian peppermint & $\checkmark$ & $\checkmark$ & \\
\hline Albizia julibrissin & Mimosa, silk tree & $\checkmark$ & & $\checkmark$ \\
\hline Aloysia citrodora & lemon verbena & $\checkmark$ & & \\
\hline
\end{tabular}




\begin{tabular}{|c|c|c|c|c|}
\hline SCIENTIFIC NAME & COMMON NAME & $\begin{array}{l}\text { VUW } \\
61-82\end{array}$ & $\begin{array}{l}\text { VUW } \\
1990\end{array}$ & $\begin{array}{l}\text { VUW } \\
14-15\end{array}$ \\
\hline Alnus rubra & red alder & & & \\
\hline $\begin{array}{l}\text { Amelanchier canadensis var. } \\
\text { canadensis }\end{array}$ & Canadian serviceberry & $\checkmark$ & $\checkmark$ & \\
\hline Anigozanthos flavidus & evergreen kangaroo paw & & $\bar{\checkmark}$ & \\
\hline Arbutus unedo & strawberry tree & & $\bar{\checkmark}$ & \\
\hline Aucuba japonica & & $\checkmark$ & $\checkmark$ & $\checkmark$ \\
\hline Banksia spinulosa var. collina & hairpin banksia & $\checkmark$ & & \\
\hline Banksia ericifolia & heath-leaved banksia & $\checkmark$ & & \\
\hline Banksia integrifolia & & $\bar{\checkmark}$ & & $\checkmark$ \\
\hline Bauera sessiliflora & Grampians bauera & $\checkmark$ & & \\
\hline Berberis darwinii & & & & $\checkmark$ \\
\hline Berberis thunbergii & Japanese berberis & $\checkmark$ & $\checkmark$ & \\
\hline Betula pendula & silver birch & & $\checkmark$ & $\checkmark$ \\
\hline Betula sp. & & & & $\checkmark$ \\
\hline Brugmansia suaveolins & datura, angel trumpet & & $\bar{\checkmark}$ & \\
\hline Buddleja davidii & & $\checkmark$ & $\checkmark$ & $\checkmark$ \\
\hline Buxus sempervirens & box & & $\bar{\checkmark}$ & \\
\hline Calistemmon citrinus & bottlebrush & $\checkmark$ & $\bar{\checkmark}$ & $\checkmark$ \\
\hline Callistemon 'Lilacinus' & bottlebrush & $\checkmark$ & . & \\
\hline Calluna vulgaris & common heather & & $\bar{\checkmark}$ & \\
\hline Camellia sp. & camellia & & $\checkmark$ & $\checkmark$ \\
\hline Camellia japonica & & $\checkmark$ & $\checkmark$ & \\
\hline Camellia reticulata & & $\checkmark$ & & \\
\hline Camellia sasanqua & & $\checkmark$ & $\checkmark$ & \\
\hline Caryopteris $\times$ clandonensis & bluebeard & $\checkmark$ & & \\
\hline Cassia sp. & & & $\bar{\checkmark}$ & \\
\hline Casuarina cunninghamiana & sheoak & $\checkmark$ & $\bar{\checkmark}$ & \\
\hline Casuarina equisetifolia & sheoak & $\checkmark$ & & $\checkmark$ \\
\hline Catha edulis & khat & & $\checkmark$ & \\
\hline $\begin{array}{l}\text { Ceanothus cuneatus var. } \\
\text { cuneatus }\end{array}$ & coastal buckbrush & $\checkmark$ & & \\
\hline $\begin{array}{l}\text { Ceanothus papillosus var. } \\
\text { roweanus }\end{array}$ & Californian lilac & $\checkmark$ & $\checkmark$ & \\
\hline Chaenomeles japonica cv. & Japanese quince & $\checkmark$ & & \\
\hline Chaenomeles $\mathrm{x}$ superba & quince & $\checkmark$ & $\bar{\checkmark}$ & \\
\hline Chamaecytisus palmensis & tree lucerne, tagasaste & $\checkmark$ & $\checkmark$ & $\checkmark$ \\
\hline Chimonanthus praecox & wintersweet & $\checkmark$ & $\bar{\checkmark}$ & $\checkmark$ \\
\hline Choisya ternata & mock orange & $\checkmark$ & $\bar{\checkmark}$ & $\checkmark$ \\
\hline Coleonema pulchellum & breath of heaven & $\checkmark$ & & \\
\hline Cornus capitata & Himalayan flowering dogwood & & & $\checkmark$ \\
\hline
\end{tabular}




\begin{tabular}{|c|c|c|c|c|}
\hline SCIENTIFIC NAME & COMMON NAME & $\begin{array}{l}\text { VUW } \\
61-82\end{array}$ & $\begin{array}{l}\text { VUW } \\
1990\end{array}$ & $\begin{array}{l}\text { VUW } \\
14-15\end{array}$ \\
\hline Cornus kousa & Japanese dogwood & $\checkmark$ & & \\
\hline Correa alba & white correa & & $\checkmark$ & \\
\hline Correa pulchella & salmon correa & & $\bar{\checkmark}$ & \\
\hline Correa sp. & & & $\checkmark$ & $\checkmark$ \\
\hline Corylopsis spicata & winter hazel & $\checkmark$ & & \\
\hline Corymbia ficifolia & red flowering gum & & $\checkmark$ & \\
\hline Cotoneaster conspicuus & Tibetan cotoneaster & $\checkmark$ & & \\
\hline Cotoneaster dammeri & bearberry & $\checkmark$ & $\checkmark$ & \\
\hline Cotoneaster lactea & & & & $\checkmark$ \\
\hline Cotoneaster microphyllus & small-leaved cotoneaster & $\checkmark$ & $\checkmark$ & \\
\hline Cotoneaster simonsii & & & $\checkmark$ & \\
\hline Cotinus coggygria & European smoketree & $\checkmark$ & & \\
\hline Crataegus monogyna & common hawthorn & $\checkmark$ & $\checkmark$ & \\
\hline Cytisus scoparius & common broom & $\checkmark$ & & $\checkmark$ \\
\hline Drymus winteri & canelo & & $\bar{\checkmark}$ & $\checkmark$ \\
\hline Erica sp. & heath, heather & & & $\checkmark$ \\
\hline Escallonia cv. & & & & $\checkmark$ \\
\hline Escallonia rubra var. macrantha & red-flowered escallonia & $\checkmark$ & $\bar{\checkmark}$ & \\
\hline Eucalyptus leucoxylon & blue gum & $\checkmark$ & & \\
\hline Eucalyptus sp. & & & & $\checkmark$ \\
\hline Euonymus japonicus & spindle tree & $\checkmark$ & $\checkmark$ & $\checkmark$ \\
\hline Fatsia japonica & Japanese aralia & $\checkmark$ & $\checkmark$ & $\checkmark$ \\
\hline Ficus carica & common fig & 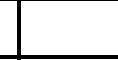 & $\checkmark$ & \\
\hline Ficus macrophylla & Moreton Bay fig & $\checkmark$ & 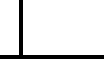 & \\
\hline Forsythia sp. & & $\checkmark$ & $\checkmark$ & \\
\hline Fraxinus excelsior & European ash & . & $\bar{\checkmark}$ & \\
\hline Fraxinus oxycarpa var. raywoodii & Raywood ash & $\checkmark$ & $\checkmark$ & \\
\hline Fuchsia arborescens & South American tree fuchsia & & $\checkmark$ & \\
\hline Fuchsia magellanica & hummingbird fuchsia & $\checkmark$ & & \\
\hline Garrya elliptica & & $\checkmark$ & & \\
\hline Genista canariensis & Canary Island broom & $\checkmark$ & & \\
\hline Genista monspessulana & Montpellier broom & $\checkmark$ & $\checkmark$ & $\checkmark$ \\
\hline Gordonia axillaris & & $\checkmark$ & & \\
\hline Grevillea fasciculata & & & $\checkmark$ & \\
\hline Grevillea juniperina & & $\checkmark$ & & \\
\hline $\begin{array}{l}\text { Grevillea juniperina subsp. } \\
\text { sulphurea }\end{array}$ & & $\checkmark$ & & \\
\hline Grevillea lavandulacea & lavender grevillea & $\checkmark$ & & \\
\hline Grevillea oleoides & & $\checkmark$ & & \\
\hline Grevillea rosmarinifolia & & $\checkmark$ & $\bar{\checkmark}$ & \\
\hline
\end{tabular}




\begin{tabular}{|c|c|c|c|c|}
\hline SCIENTIFIC NAME & COMMON NAME & $\begin{array}{l}\text { VUW } \\
61-82\end{array}$ & $\begin{array}{l}\text { VUW } \\
1990\end{array}$ & $\begin{array}{l}\text { VUW } \\
14-15\end{array}$ \\
\hline Gaultheria mucronata & prickly heath & $\checkmark$ & & \\
\hline Hakea rostrata & beaked pincushion tree & $\checkmark$ & & \\
\hline Hibiscus syriacus & & $\checkmark$ & & \\
\hline Hydrangea macrophylla & & $\checkmark$ & $\checkmark$ & \\
\hline Hypericum cv. Hidcote gold & & $\checkmark$ & & \\
\hline Hypericum sp. & & & $\checkmark$ & \\
\hline Hypercum $\mathrm{x}$ moserianum & & & $\checkmark$ & \\
\hline Idesia polycarpa & wonder tree & $\checkmark$ & 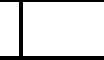 & \\
\hline Ilex aquifolium & holly & $\checkmark$ & $\checkmark$ & $\checkmark$ \\
\hline Kerria japonica & Japanese rose & & $\checkmark$ & \\
\hline Kunzea parvifolia & violet kunzea & & $\checkmark$ & \\
\hline Laurus nobilis & bay tree & & $\checkmark$ & $\checkmark$ \\
\hline Leucadendron discolor & & $\checkmark$ & & \\
\hline Leucadendron salignum & & $\checkmark$ & $\checkmark$ & \\
\hline Leucadendron sp. & & & $\checkmark$ & $\checkmark$ \\
\hline Leycesteria formosa & Himalayan honeysuckle & $\checkmark$ & & \\
\hline Ligustrum ovalifolium & privet & 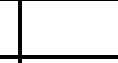 & $\checkmark$ & $\checkmark$ \\
\hline Liquidambar styraciflua & American sweetgum & $\checkmark$ & ( & \\
\hline Luculia gratissima & & $\checkmark$ & $\bar{\checkmark}$ & \\
\hline Magnolia grandiflora & & $\checkmark$ & $\checkmark$ & $\checkmark$ \\
\hline Mahonia aquifolium & Oregon grape & $\checkmark$ & . & \\
\hline Mahonia bealei & & & $\checkmark$ & \\
\hline Malus domestica & apple & $\checkmark$ & $\checkmark$ & $\checkmark$ \\
\hline Malva dendromorpha & & & & $\checkmark$ \\
\hline Maytenus boaria & & $\checkmark$ & & $\checkmark$ \\
\hline Metrosideros collina & Tahitian pohutukawa & & $\checkmark$ & \\
\hline Michelia cv. & & & & $\checkmark$ \\
\hline Morus nigra & black mulberry & 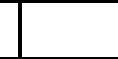 & $\checkmark$ & \\
\hline Myoporum aff. insulare & boobialla & $\checkmark$ & & $\checkmark$ \\
\hline Nematolepis squamea & satinwood & $\checkmark$ & $\checkmark$ & $\checkmark$ \\
\hline Nerium oleander & oleander & $\checkmark$ & & \\
\hline Olea europaea & olive & $\checkmark$ & & $\checkmark$ \\
\hline Olearia phlogopappa & dusty daisy bush & $\checkmark$ & & \\
\hline Osmanthus sp. & & $\checkmark$ & & \\
\hline Paraserianthes lophantha & brush wattle & $\checkmark$ & $\checkmark$ & $\checkmark$ \\
\hline Persoonia pinifolia & pine-leaved geebung & $\checkmark$ & & \\
\hline Photinia glabra & Japanese photinia & $\checkmark$ & $\checkmark$ & \\
\hline Photinia $\times$ fraseri & & & $\checkmark$ & $\checkmark$ \\
\hline Philotheca myoporoides & long-leaf wax flower & $\checkmark$ & & \\
\hline
\end{tabular}




\begin{tabular}{|c|c|c|c|c|}
\hline SCIENTIFIC NAME & COMMON NAME & $\begin{array}{l}\text { VUW } \\
61-82\end{array}$ & $\begin{array}{l}\text { VUW } \\
1990\end{array}$ & $\begin{array}{l}\text { VUW } \\
14-15\end{array}$ \\
\hline Pieris japonica & lily of the valley tree & $\checkmark$ & $\checkmark$ & $\checkmark$ \\
\hline Pittosporum undulatum & Australian cheesewood & $\checkmark$ & & \\
\hline $\begin{array}{l}\text { Platanus orientalis var. insularis } \\
\text { cv. autumn glory }\end{array}$ & plane tree & $\checkmark$ & & \\
\hline Podalyria calyptrata & & $\checkmark$ & & \\
\hline Polygala myrtifolia & myrtle-leaf milkwort & & $\checkmark$ & \\
\hline Populus sp. & poplar & & & $\checkmark$ \\
\hline Prostanthera cuneata & & & $\checkmark$ & \\
\hline Protea amplexicaulis & rodent sugarbush & & $\checkmark$ & \\
\hline Protea cynaroides & king protea & $\checkmark$ & $\checkmark$ & \\
\hline Protea grandiceps & protea & & $\checkmark$ & \\
\hline Protea lacticolor & sugarbush & $\checkmark$ & & \\
\hline Protea magnifica & queen sugarbush & $\checkmark$ & & \\
\hline Protea nana & mountain rose & & $\bar{\checkmark}$ & \\
\hline Protea neriifolia & oleander-leaf protea & $\checkmark$ & . & \\
\hline Protea scolymocephala & thistle protea & $\checkmark$ & & \\
\hline Protea sp. & & & $\checkmark$ & \\
\hline Prunus cerasifera & cherry plum & & $\checkmark$ & \\
\hline Prunus sp. & & & $\checkmark$ & $\checkmark$ \\
\hline Prunus lauracerasus & cherry laurel & & $\checkmark$ & $\checkmark$ \\
\hline Prunus mume & choke cherry & $\checkmark$ & & \\
\hline Prunus serrulata & Japanese cherry & & & $\checkmark$ \\
\hline Pyracantha coccinea & scarlet firethorn & $\checkmark$ & $\checkmark$ & \\
\hline Quercus ilex & holm oak & & & $\checkmark$ \\
\hline Raphiolepis sp. & & $\checkmark$ & $\checkmark$ & \\
\hline Rhododendron indicum & & $\checkmark$ & $\checkmark$ & \\
\hline Rhododendron eriocarpum & & $\checkmark$ & & \\
\hline Rhododenron japonicum & & $\checkmark$ & & \\
\hline Rhododendron molle & & $\checkmark$ & $\checkmark$ & \\
\hline Rhododendron sp. & & $\checkmark$ & $\checkmark$ & $\checkmark$ \\
\hline Ribes sanguineum & flowering currant & & $\checkmark$ & \\
\hline Rosa sp. & rose & . & $\checkmark$ & \\
\hline Salix alba & white willow & $\checkmark$ & & \\
\hline Salix matsudana & tortured willow & $\checkmark$ & . & \\
\hline Salix sp. & willow & . & $\checkmark$ & $\checkmark$ \\
\hline Sambucus nigra & elder & $\checkmark$ & $\checkmark$ & \\
\hline Sarcococca ruscifolia & fragrant sweetbox & $\checkmark$ & & \\
\hline Schefflera actinophylla & Queensland umbrella tree & $\checkmark$ & & \\
\hline Schinus molle & Peruvian pepper & $\checkmark$ & $\checkmark$ & \\
\hline
\end{tabular}




\begin{tabular}{|c|c|c|c|c|}
\hline SCIENTIFIC NAME & COMMON NAME & $\begin{array}{l}\text { VUW } \\
61-82\end{array}$ & $\begin{array}{l}\text { VUW } \\
1990\end{array}$ & $\begin{array}{l}\text { VUW } \\
14-15\end{array}$ \\
\hline Senecio angulatus & Cape ivy & $\checkmark$ & $\checkmark$ & \\
\hline Senna corymbosa & Argentine senna & & & \\
\hline Serruria sp. & & & $\bar{\checkmark}$ & \\
\hline Sorbus aucuparia & rowan, mountain ash & $\checkmark$ & & \\
\hline Spartium junceum & Spanish broom & $\checkmark$ & & \\
\hline Stachyurus praecox & & $\checkmark$ & & \\
\hline Stransvaesia davidiana & Chinese photinia & $\checkmark$ & & $\checkmark$ \\
\hline Syringa vulgaris & common lilac & $\checkmark$ & $\checkmark$ & \\
\hline Syzygium smithii & lilly pilly & $\checkmark$ & & $\checkmark$ \\
\hline Syzygium sp. & & & & $\checkmark$ \\
\hline Tamarix sp. & tamarisk, salt cedar & $\checkmark$ & $\checkmark$ & \\
\hline Taxandria marginata & & & & $\checkmark$ \\
\hline Taxus baccata & yew & & $\checkmark$ & \\
\hline Teucrium fruticans & silver germander & & $\checkmark$ & \\
\hline Thryptomene calycina & Grampians heath myrtle & $\checkmark$ & & \\
\hline Tibouchina semidecandra & lasiandra & & $\checkmark$ & \\
\hline Tilia americana & American basswood & & $\checkmark$ & \\
\hline Tilia $\mathrm{x}$ europaea & common lime & & & $\checkmark$ \\
\hline Toxicodendron succedaneum & Japanese wax tree & & $\bar{\checkmark}$ & \\
\hline Ugni molinae & Chilean guava & & $\checkmark$ & \\
\hline Ulex europeus & gorse & $\checkmark$ & & $\checkmark$ \\
\hline Ulmus parvifolia & Chinese elm & $\checkmark$ & & \\
\hline Viburnum carlesii & Korean spice & $\checkmark$ & & \\
\hline Viburnum davidii & viburnum & & $\checkmark$ & \\
\hline Viburnum japonicum & & $\checkmark$ & $\checkmark$ & \\
\hline Viburnum opulus & European cranberry bush & $\checkmark$ & $\checkmark$ & \\
\hline Viburnum plicatum & Japanese snowball tree & $\checkmark$ & . & \\
\hline Viburnum sp. & & & $\checkmark$ & $\checkmark$ \\
\hline Viburnum tinus & & & $\checkmark$ & \\
\hline Viburnum $\times$ burkwoodii & & & $\checkmark$ & \\
\hline Virgilia oroboides & Cape lilac & $\checkmark$ & & $\checkmark$ \\
\hline Weigela cv. & & $\checkmark$ & & $\checkmark$ \\
\hline Westringia rosmarinifolia & & & $\checkmark$ & \\
\hline
\end{tabular}


BARK (GROUNDS CONTRACTOR) MANAGEMENT ZONES

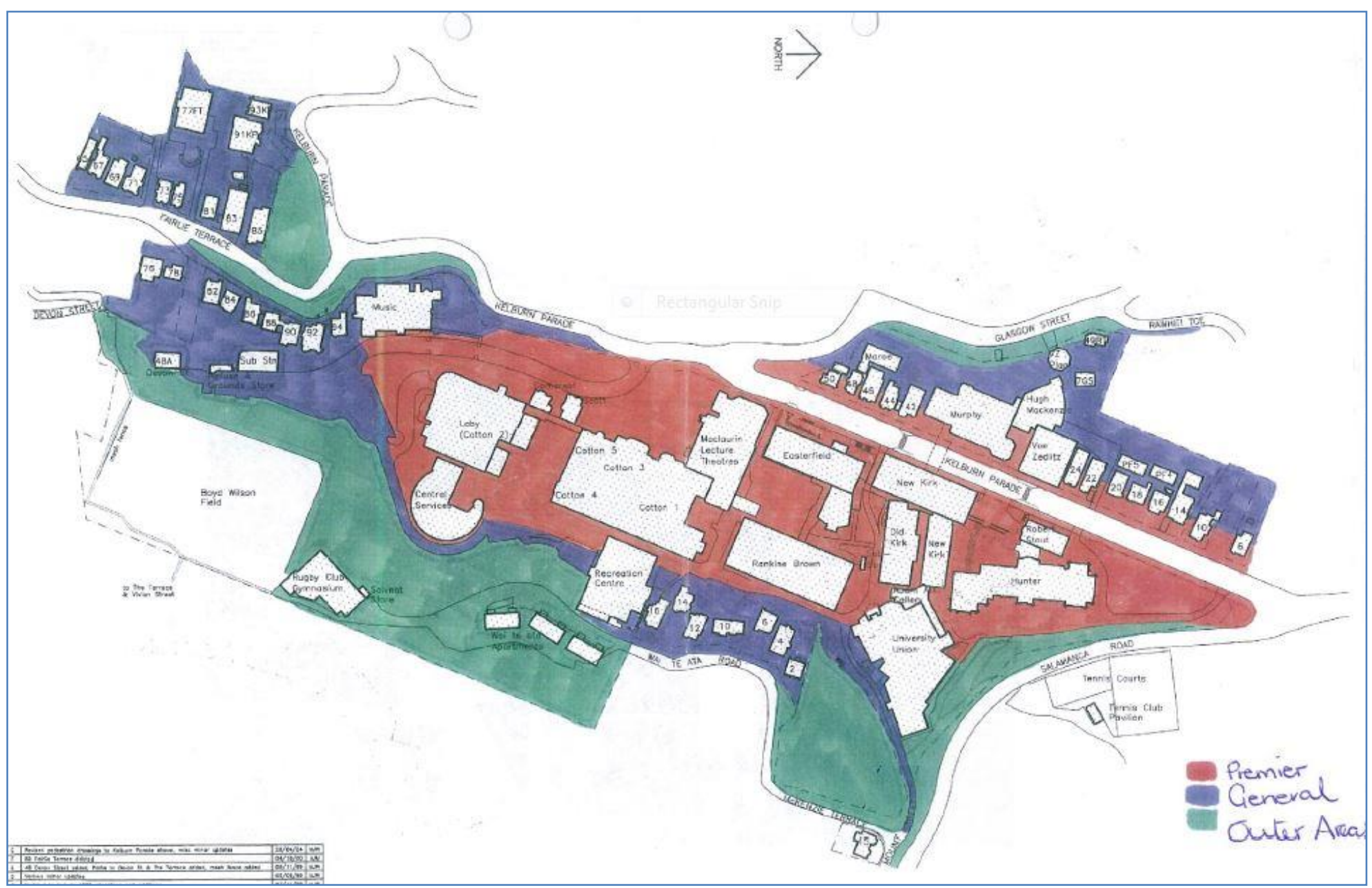




\section{INVENTORY OF ALL SPECIES OCCURRING ON THE KELBURN CAMPUS}

Nomenclature is based on the New Zealand Plant Conservation Network (www.nzpcn.org), the Integrated Taxonomic Information System (itis.gov) a partnership of United States, Canadian and Mexican Agencies, the Electronic Plant Information Centre, Kew Gardens (epic.kew.org/index.htm), and the Australian Plant Name Index (anbg.gov.au). The naming for Kunzea spp. follows the pre de Lange (2014) revision.

Campus trees. Introduced species are marked with an asterisk

177 species, 112 indigenous and 65 introduced, 115 genera from 66 taxa, and a total of 5,967 stems. There are 816 individual introduced trees and the remainder $(5,151)$ are indigenous. Indigenous trees and shrubs from 42 taxa are represented by 53 genera. Introduced trees and shrubs from 34 taxa are represented by 60 genera.

\begin{tabular}{|l|l|l|l|}
\hline Taxa & Genera & Species & Frequency \\
\hline Aceraceae & Acer & pseudoplatanus* & * \\
\hline Adoxaceae & Sambucus & nigra* $^{*}$ & 43 \\
\hline & Viburnum & sp. $^{*}$ & 6 \\
\hline Alseuosmiaceae & Alseuosmia & macrophylla $^{*}$ & 2 \\
\hline Aquifoliaceae & Ilex & aquifolium $^{*}$ & 26 \\
\hline Araliaceae & Fatsia & japonica* $^{*}$ & 22 \\
\hline & Meryta & sinclairii & 36 \\
\hline & Pseudopanax & arboreus & 226 \\
\hline & & colensoi var. colensoi & 4 \\
\hline & & crassifolius & 51 \\
\hline & & crassifolius x lessonii & 96 \\
\hline & & ferox & 85 \\
\hline & & lessonii & 39 \\
\hline & Schlefflera & digitata & 25 \\
\hline Araucariaceae & Agathis & australis & 4 \\
\hline Arecaceae & Howea & forsteriana & 3 \\
\hline & Rhopalostylis & sapida & 8 \\
\hline Argophyllaceae & Corokia & buddleioides & 1 \\
\hline & & cotoneaster & 21 \\
\hline & & macrocarpa & 24 \\
\hline Asparagaceae & Cordyline & australis & 207 \\
\hline
\end{tabular}




\begin{tabular}{|c|c|c|c|}
\hline Taxa & Genera & Species & Frequency \\
\hline \multirow[t]{6}{*}{ Asteraceae } & Brachyglottis & repanda & 322 \\
\hline & Olearia & avicenniifolia & 1 \\
\hline & & lineata & 2 \\
\hline & & paniculata & 59 \\
\hline & & solandri & 20 \\
\hline & & sp. & 2 \\
\hline Berberidaceae & Berberis & darwinii $^{*}$ & 14 \\
\hline \multirow[t]{2}{*}{ Betulaceae } & Betula & pendula* & 2 \\
\hline & & $\mathrm{sp.}^{*}$ & 4 \\
\hline Calycanthaceae & Chimonanthus & praecox $^{*}$ & 2 \\
\hline Caprifoliaceae & Weigela & cv. ${ }^{*}$ & 1 \\
\hline Casuarinaceae & Casuarina & equisetifolia* & 5 \\
\hline \multirow[t]{2}{*}{ Celastraceae } & Euonymous & japonicus* & 17 \\
\hline & Maytenus & boaria* & 3 \\
\hline Cornaceae & Cornus & capitata* $^{*}$ & 5 \\
\hline Corynocarpaceae & Corynocarpus & laevigatus & 73 \\
\hline Cunoniaceae & Ackama & rosifolia & 14 \\
\hline \multirow[t]{4}{*}{ Cupressaceae } & Chamaecyparis & lawsoniana "Wissel's saguaro"* & 1 \\
\hline & Cupressus & macrocarpa* & 1 \\
\hline & Juniperus & chinensis* $^{*}$ & 2 \\
\hline & Libocedrus & plumosa & 6 \\
\hline \multirow[t]{2}{*}{ Cyatheaceae } & Cyathea & dealbata & 27 \\
\hline & & medullaris & 137 \\
\hline Dicksoniaceae & Dicksonia & squarrosa & 18 \\
\hline \multirow[t]{2}{*}{ Elaeocarpaceae } & Aristotelia & serrata & 11 \\
\hline & Elaeocarpus & dentatus var. dentatus & 1 \\
\hline \multirow[t]{3}{*}{ Ericaceae } & Erica & sp. $^{*}$ & 1 \\
\hline & Pieris & japonica* & 1 \\
\hline & Rhododendron & $\mathrm{sp}^{*}$ & 5 \\
\hline Escalloniaceae & Escallonia & $\mathrm{CV}^{*}$ & 1 \\
\hline \multirow[t]{12}{*}{ Fabaceae } & Albizia & julibrisson & 1 \\
\hline & Carmichaelia & sp. & 8 \\
\hline & Chamaecytisus & palmensis* & 39 \\
\hline & Cytisus & scoparius* $^{*}$ & 53 \\
\hline & Genista & monspessulana* & 2 \\
\hline & Paraserianthes & lophantha* & 78 \\
\hline & Sophora & microphylla & 44 \\
\hline & & microphylla $x$ & 1 \\
\hline & & molloyi & 34 \\
\hline & & tetraptera & 15 \\
\hline & Ulex & europeus* & 151 \\
\hline & Virgilia & oroboides* & 4 \\
\hline Fagaceae & Quercus & ilex $x^{*}$ & 1 \\
\hline
\end{tabular}




\begin{tabular}{|c|c|c|c|}
\hline Taxa & Genera & Species & Frequency \\
\hline Garryaceae & Acuba & japonica* & 3 \\
\hline Ginkgoaceae & Ginkgo & biloba* $^{*}$ & 1 \\
\hline Griseliniaceae & Griselinia & littoralis & 119 \\
\hline Lamiaceae & Teucridium & parvifolium & 2 \\
\hline Lamiaceae & Vitex & lucens & 9 \\
\hline Lauraceae & Laurus & nobilis* & 10 \\
\hline Loganiaceae & Geniostoma & ligustrifolium var. ligustrifolium & 71 \\
\hline \multirow[t]{2}{*}{ Magnoliaceae } & Magnolia & grandiflora* $^{*}$ & 1 \\
\hline & Michelia & $\mathrm{CV}^{*}$ & 8 \\
\hline \multirow[t]{5}{*}{ Malvaceae } & Entelea & arborescens & 24 \\
\hline & Hoheria & populnea & 28 \\
\hline & & sexstylosa & 26 \\
\hline & Malva & dendromorpha* & 1 \\
\hline & Tilia & x europaea* & 6 \\
\hline Monimiaceae & Hedycarya & arborea & 2 \\
\hline \multirow[t]{2}{*}{ Moraceae } & Streblus & banksii & 8 \\
\hline & & heterophyllus & 3 \\
\hline \multirow[t]{15}{*}{ Myrtaceae } & Calistemmon & citrinus $^{*}$ & 4 \\
\hline & Eucalyptus & $\mathrm{sp.}^{*}$ & 65 \\
\hline & Kunzea & ericoides & 85 \\
\hline & Leptospermum & scoparium & 11 \\
\hline & Lophomyrtus & bullata & 16 \\
\hline & & obcordatum & 3 \\
\hline & Metrosideros & excelsa & 211 \\
\hline & & excelsa $\times$ kermadecensis & 5 \\
\hline & & excelsa x robusta & 2 \\
\hline & & kemadecensis & 8 \\
\hline & & robusta & 8 \\
\hline & & umbellata & 1 \\
\hline & Syzygium & smithii $^{*}$ & 2 \\
\hline & & sp. $^{*}$ & 1 \\
\hline & Taxandria & marginata* & 2 \\
\hline \multirow[t]{3}{*}{ Northofagaceae } & Fuscospora & solandri & 1 \\
\hline & & truncata & 11 \\
\hline & Lophozonia & menziesii & 4 \\
\hline \multirow[t]{3}{*}{ Oleaceae } & Ligustrum & ovalifolium* & 3 \\
\hline & Nestegis & lanceolata & 5 \\
\hline & Olea & europaea* $^{*}$ & 2 \\
\hline Pennantiaceae & Pennantia & corymbosa & 9 \\
\hline Phyllocladaceae & Phyllocladus & trichomanoides & 1 \\
\hline \multirow[t]{3}{*}{ Pinaceae } & Pinus & patula* & 4 \\
\hline & & radiata* $^{*}$ & 3 \\
\hline & & $\mathrm{sp.}^{*}$ & 4 \\
\hline
\end{tabular}




\begin{tabular}{|c|c|c|c|}
\hline Taxa & Genera & Species & Frequency \\
\hline \multirow[t]{2}{*}{ Piperaceae } & Piper & excelsum subsp. excelsum & 964 \\
\hline & & excelsum subsp. psittacorum & 12 \\
\hline \multirow[t]{7}{*}{ Pittosporaceae } & Pittosporum & cornifolium & 1 \\
\hline & & crassifolium & 128 \\
\hline & & eugenioides & 147 \\
\hline & & obcordatum & 1 \\
\hline & & ralphii & 56 \\
\hline & & sp. & 1 \\
\hline & & tenuifolium & 90 \\
\hline \multirow[t]{7}{*}{ Plantaginaceae } & Veronica & cv. wiri & 32 \\
\hline & & ligustrifolia & 44 \\
\hline & & parviflora & 14 \\
\hline & & sp. & 17 \\
\hline & & speciosa & 71 \\
\hline & & stricta var. stricta & 6 \\
\hline & & tairawhiti & 3 \\
\hline \multirow[t]{4}{*}{ Podocarpaceae } & Dacrycarpus & dacrydioides & 2 \\
\hline & Podocarpus & sp. $^{*}$ & 1 \\
\hline & & totara & 16 \\
\hline & Prumnopitys & ferruginea & 4 \\
\hline Podocarpaceae & Prumnopitys & taxifolia & 3 \\
\hline Polygonaceae & Muehlenbeckia & astonii & 5 \\
\hline \multirow[t]{2}{*}{ Primulaceae } & Myrsine & australis & 7 \\
\hline & & salicina & 1 \\
\hline \multirow[t]{3}{*}{ Proteaceae } & Banksia & integrifolia* & 1 \\
\hline & Knightia & excelsa & 10 \\
\hline & Leucadendron & $\mathrm{sp.}^{*}$ & 2 \\
\hline Rhamnaceae & Pomaderris. & apetala subsp. maritima & 5 \\
\hline \multirow[t]{7}{*}{ Roseaceae } & Cotoneaster & lactea* & 1 \\
\hline & Malus & domestica & 1 \\
\hline & Stranvaesia & davidiana* & 5 \\
\hline & Photinia & $\mathrm{x}$ fraseri $^{*}$ & 1 \\
\hline & Prunus & $\mathrm{CV}^{*}$ & 7 \\
\hline & & lauracerasus* & 3 \\
\hline & & serrulata* $^{*}$ & 36 \\
\hline Rousseaceae & Carpodetus & serratus & 4 \\
\hline \multirow[t]{7}{*}{ Rubiaceae } & Coprosma & foetidissima & 1 \\
\hline & & grandifolia & 92 \\
\hline & & macrocarpa subsp. macrocarpa & 3 \\
\hline & & microcarpa & 4 \\
\hline & & parviflora & 9 \\
\hline & & propinqua & 4 \\
\hline & & repens & 107 \\
\hline
\end{tabular}




\begin{tabular}{|c|c|c|c|}
\hline Taxa & Genera & Species & Frequency \\
\hline & & repens aff. Poor Knights & 1 \\
\hline & & rhamnoides & 6 \\
\hline & & robusta & 119 \\
\hline & & robusta $\times$ propinqua & 3 \\
\hline & & $\mathrm{sp}$. & 3 \\
\hline & & virescens & 22 \\
\hline \multirow[t]{4}{*}{ Rutaceae } & Choisya & ternata* & 3 \\
\hline & Correa & sp. $^{*}$ & 1 \\
\hline & Melicope & ternata & 55 \\
\hline & Nematolepis & squamea* & 8 \\
\hline \multirow[t]{2}{*}{ Salicaceae } & Populus & sp. $^{*}$ & 1 \\
\hline & Salix & sp. $^{*}$ & 2 \\
\hline \multirow[t]{2}{*}{ Sapindaceae } & Alectryon & excelsus & 12 \\
\hline & Dodonaea & viscosa & 52 \\
\hline Sapotaceae & Planchonella & costata & 6 \\
\hline \multirow[t]{4}{*}{ Scrophulariaceae } & Buddleja & davidii $^{*}$ & 9 \\
\hline & Myoporum & aff. insulare* & 2 \\
\hline & & laetum & 63 \\
\hline & & semotum & 1 \\
\hline Taxodiaceae & Sequoia & sempervirens* & 1 \\
\hline Theaceae & Camellia & sp. $^{*}$ & 79 \\
\hline Urticaceae & Pouzolzia & australis & 1 \\
\hline \multirow[t]{7}{*}{ Violaceae } & Melicytus & chathamicus & 2 \\
\hline & & crassifolius & 3 \\
\hline & & lanceolatus & 1 \\
\hline & & macrophyllus & 2 \\
\hline & & novae-zelandiae & 1 \\
\hline & & obovatus & 9 \\
\hline & & ramiflorus subsp. ramiflorus & 607 \\
\hline Winteraceae & Drymus & winteri* $^{*}$ & 2 \\
\hline
\end{tabular}


SPECIES THAT OCCUR ONLY INFREQUENTLY

Indigenous spp.

\begin{tabular}{|c|c|c|}
\hline Species with four specimens $t=13$ & $\begin{array}{l}\text { Species with three specimens } \\
t=14\end{array}$ & Species with two specimens $t=20$ \\
\hline Agathis australis & Acuba japonica & Alseuosmia macrophylla \\
\hline Betula sp & Choisya ternata & Betula pendula \\
\hline Calistemmon citrinus & $\begin{array}{l}\text { Coprosma macrocarpa subsp. } \\
\text { Macrocarpa }\end{array}$ & Chimonanthus praecox \\
\hline Carpodetus serratus & Coprosma sp & Dacrycarpus dacrydioides \\
\hline Coprosma microcarpa & Coprosma robusta $\mathrm{x}$ propinqua & Drymus winteri \\
\hline Coprosma propinqua & Hebe ligustrifolia & Genista monspessulana \\
\hline Lophozonia menziesii & Ligustrum ovalifolium & Hedycarya arborea \\
\hline Pinus patula & Lophomyrtus obcordatum & Juniperus chinensis \\
\hline Pinus sp & Maytenus boaria & Leucadendron sp. \\
\hline Prumnopitys ferruginea & Melicytus crassifolius & Melicytus chathamicus \\
\hline Pseudopanax colensoi var. Colensoi & Pinus radiata & Melicytus macrophyllus \\
\hline Sambuca nigra & Prunus lauracerasus & Metrosideros excelsa $x$ robusta \\
\hline \multirow[t]{6}{*}{ Virgilia oroboides } & Prumnopitys taxifolia & Myoporum aff. insulare \\
\hline & Streblus heterophyllus & Olea europaea \\
\hline & & Olearia lineata \\
\hline & & Olearia sp. \\
\hline & & Salix sp. \\
\hline & & Syzygium smithii \\
\hline
\end{tabular}

Species with one specimen $t=35$

Banksia integrifolia

Chamaecyparis lawsoniana

"Wissel's saguaro"

Coprosma foetidissima

Coprosma repens aff. Poor Knights

Corokia buddleioides

Correa sp.

Cotoneaster lactea

Cupressus macrocarpa

Erica $\mathrm{sp}$

Escallonia cv

Fuscospora solandri

Ginkgo biloba

Magnolia grandiflora

Malva dendromorpha

Malus domestica

Melicytus lanceolatus

Melicytus novae-zelandiae

Metrosideros umbellata 


\begin{tabular}{|l|l|l|l|}
\hline Species with four specimens $\mathbf{t = 1 3}$ & $\begin{array}{l}\text { Species with three specimens } \\
\boldsymbol{t = 1 4}\end{array}$ & Species with two specimens $\mathbf{t = 2 0}$ & Species with one specimen $\boldsymbol{t = 3 5}$ \\
\hline & & Taxandria marginata & Myoporum semotum \\
\hline & & Teucridium parvifolium & Myrsine salicina \\
\hline & & & Olearia avicenniifolia \\
\hline & & & Photinia $\mathrm{x}$ fraseri \\
\hline & & & Phyllocladus trichomanoides \\
\hline & & & Pieris japonica \\
\hline & & & Pittosporum cornifolium \\
\hline & & & Pittosporum obcordatum \\
\hline & & & Pittosporum sp \\
\hline & & & Podocarpus sp. \\
\hline & & & Populus sp \\
\hline & & & Pouzolzia australis \\
\hline & & & Quercus ilex \\
\hline & & & Sequoia sempervirens \\
\hline & & & Sophora microphylla $x$ \\
\hline
\end{tabular}




\section{LOCATIONS OF CAMPUS PLANT COLLECTIONS}

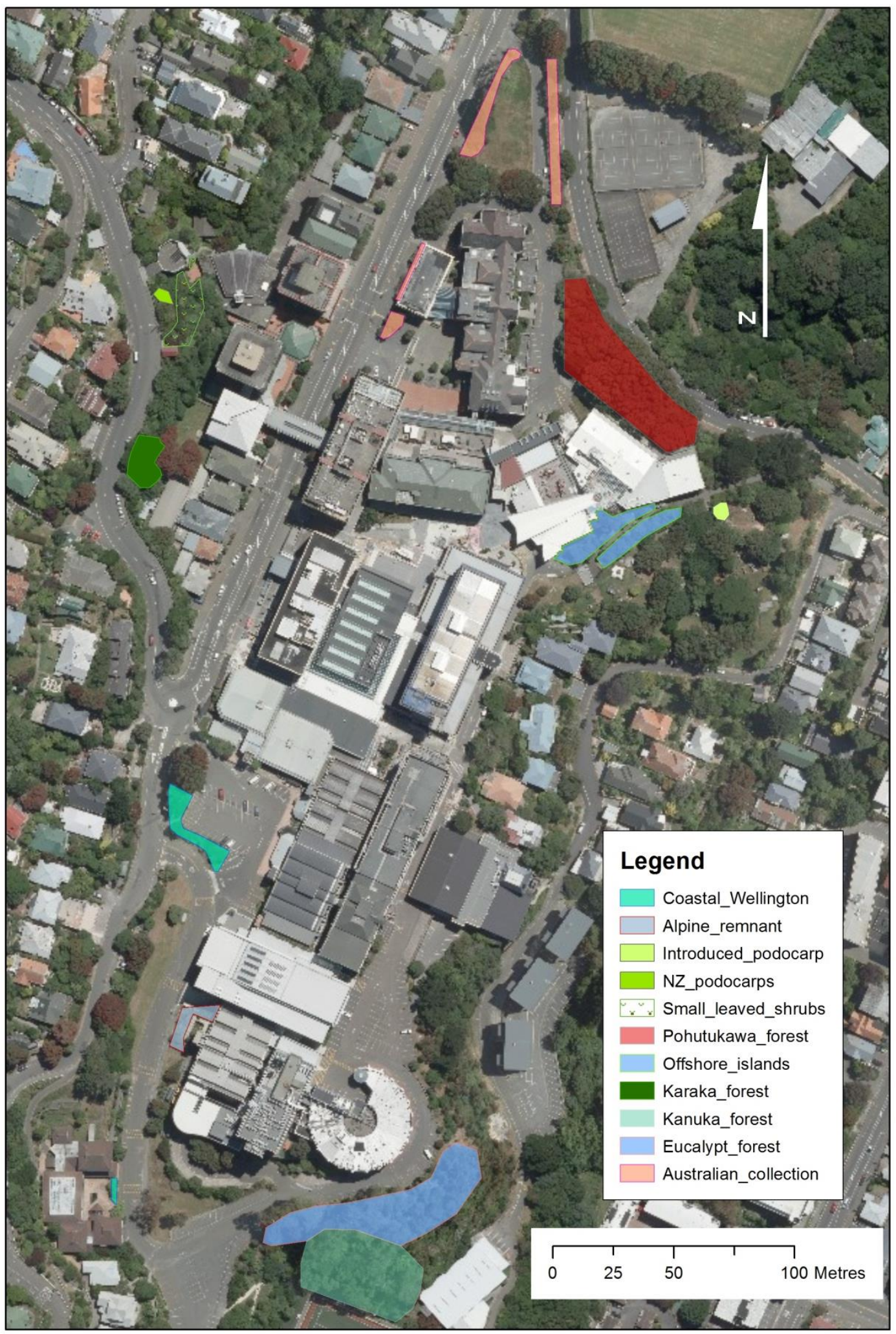




\section{TREE SPECIES RECORDED FROM THE INDIGENOUS FOREST REMNANTS AT WELLINGTON BOTANIC GARDEN AND KELBURN CAMPUS}

This table is derived from two plant checklists and provides a comparison of the current Kelburn campus indigenous trees with two lists for remnant indigenous forest at the Wellington Botanic Garden. Nomenclature is based on the New Zealand Plant Conservation Network (nzpcn.org), the Integrated Taxonomic Information System (itis.gov) a partnership of United States, Canadian and Mexican Agencies, and the Australian Plant Name Index (anbg.gov.au). The naming for Kunzea spp. follows the pre de Lange (2014) revision. The distribution column indicates non-local species. Species marked with a tick in the Myers (1987) column were also in the Buchanan (1875) list. Species marked † are known only from Buchanan.

References for the checklists are:

Myers S., 1987: Native forest remnants in Wellington's Botanic Garden. Wellington Botanical Society Bulletin 43: 32-40

Buchanan J., 1875: Notes on the Colonial Botanic Gardens, Wellington and its flora. A facsimile of a paper that was read to the Wellington Philosophical Society. (4 October 1875). Accessed online at www.nzpcn.org 24 February 2016.

\begin{tabular}{|c|c|c|c|c|}
\hline Scientific Names & Common Names & $\begin{array}{c}\text { Buchanan } \\
1875 \& \\
\text { Myers } \\
1987 \\
\end{array}$ & $\begin{array}{l}\text { Forsyth } \\
2015\end{array}$ & Distribution \\
\hline \multicolumn{5}{|l|}{ GYMNOSPERMS } \\
\hline Agathis australis & kauri & & $\checkmark$ & Not local \\
\hline Dacrycarpus dacrydioides & kahikatea & $\dagger$ & $\checkmark$ & \\
\hline Dacrydium cupressinum & rimu & $\dagger$ & & \\
\hline Libocedrus plumosa & kawaka, NZ cedar & & $\checkmark$ & \\
\hline $\begin{array}{l}\text { Phyllocladus } \\
\text { trichomanoides }\end{array}$ & celery pine & & $\checkmark$ & \\
\hline $\begin{array}{l}\text { Podocarpus totara var. } \\
\text { totara }\end{array}$ & tōtara & $\dagger$ & $\checkmark$ & \\
\hline Prumnopitys ferruginea & miro & $\dagger$ & $\checkmark$ & \\
\hline Prumnopitys taxifolia & mataī & & $\checkmark$ & \\
\hline \multicolumn{5}{|l|}{ MONOCOT TREES } \\
\hline Cordyline australis & tī kōuka, cabbage tree & & $\checkmark$ & \\
\hline Rhopalostylus sapida & nīkau & $\checkmark$ & $\checkmark$ & \\
\hline
\end{tabular}




\begin{tabular}{|c|c|c|c|c|}
\hline Scientific Names & Common Names & $\begin{array}{c}\text { Buchanan } \\
1875 \text { \& } \\
\text { Myers } \\
1987 \\
\end{array}$ & $\begin{array}{l}\text { Forsyth } \\
2015\end{array}$ & Distribution \\
\hline $\begin{array}{lll}\text { DICOT } & \text { TREES } & \text { AND } \\
\text { SHRUBS } & & \end{array}$ & & & & \\
\hline Ackama rosifolia & & & $\checkmark$ & Not local \\
\hline Alectryon excelsus & tītoki & $\checkmark$ & $\checkmark$ & \\
\hline Alseuosmia macrophylla & toropapa & & $\checkmark$ & Not local \\
\hline Aristotelia serrata & makomako, wineberry & $\checkmark$ & $\checkmark$ & \\
\hline Beilschmiedia tawa & tawa & $\checkmark$ & & \\
\hline Brachyglottis repanda & rangiora & $\checkmark$ & $\checkmark$ & \\
\hline Carmichaelia sp. & & & $\checkmark$ & \\
\hline Carpodetus serratus & putaputawētā, marbleleaf & $\checkmark$ & $\checkmark$ & \\
\hline Coprosma foetidissima & stinkwood & & $\checkmark$ & \\
\hline Coprosma grandifolia & kanono & $\checkmark$ & $\checkmark$ & \\
\hline Coprosma lucida & karamū & $\checkmark$ & & \\
\hline $\begin{array}{l}\text { Coprosma macrocarpa } \\
\text { subsp. macrocarpa }\end{array}$ & & & $\checkmark$ & Not local \\
\hline Coprosma microcarpa & & & $\checkmark$ & \\
\hline Coprosma parviflora & & & $\checkmark$ & Not local \\
\hline $\begin{array}{l}\text { Coprosma propinqua var. } \\
\text { propinqua }\end{array}$ & mingimingi & & $\checkmark$ & \\
\hline $\begin{array}{l}\text { Coprosma propinqua } \mathrm{x} \\
\text { robusta }\end{array}$ & & & $\checkmark$ & \\
\hline Coprosma repens & taupata & & $\checkmark$ & \\
\hline $\begin{array}{l}\text { Coprosma repens aff. Poor } \\
\text { Knights }\end{array}$ & & & $\checkmark$ & Not local \\
\hline Coprosma rhamnoides & & $\checkmark$ & $\checkmark$ & \\
\hline Coprosma robusta & karamū & $\checkmark$ & $\checkmark$ & \\
\hline Coprosma sp. & & & $\checkmark$ & \\
\hline Coprosma virescens & & & $\checkmark$ & \\
\hline Corynocarpus laevigatus & karaka & $\checkmark$ & $\checkmark$ & \\
\hline Corokia buddleioides & korokio & & $\checkmark$ & Not local \\
\hline Corokia cotoneaster & korokio & & $\checkmark$ & \\
\hline Corokia macrocarpa & korokio & & $\checkmark$ & Not local \\
\hline Dodonaea viscosa & akeake & $\checkmark$ & $\checkmark$ & \\
\hline Dysoxylum spectabile & kohekohe & $\checkmark$ & & \\
\hline $\begin{array}{l}\text { Elaeocarpis dentatus var. } \\
\text { dentatus }\end{array}$ & hīnau & $\checkmark$ & $\checkmark$ & \\
\hline Entelia arborescens & whau & & $\checkmark$ & \\
\hline Fuchsia excorticata & kōtukutuku, tree fuchsia & $\checkmark$ & & \\
\hline Fuscospora solandri & & & $\checkmark$ & Not local \\
\hline Fuscospora truncata & & & $\checkmark$ & Not local \\
\hline
\end{tabular}




\begin{tabular}{|c|c|c|c|c|}
\hline Scientific Names & Common Names & $\begin{array}{c}\text { Buchanan } \\
1875 \text { \& } \\
\text { Myers } \\
1987 \\
\end{array}$ & $\begin{array}{l}\text { Forsyth } \\
2015\end{array}$ & Distribution \\
\hline $\begin{array}{l}\text { Geniostoma rupestre var. } \\
\text { ligustrifolium }\end{array}$ & hangehange & $\checkmark$ & $\checkmark$ & \\
\hline Griselinia littoralis & papauma, broadleaf & & $\checkmark$ & \\
\hline Hebe cv. wiri & & & $\checkmark$ & Not local \\
\hline Hebe tairawhiti & & & $\checkmark$ & Not local \\
\hline Hedycarya arborea & porokaiwhiri, pigeonwood & $\checkmark$ & $\checkmark$ & \\
\hline Hoheria populnea & houhere, lacebark & $\checkmark$ & $\checkmark$ & \\
\hline Hoheria sexstylosa & houhere, lacebark & & $\checkmark$ & \\
\hline Knightia excelsa & rewarewa & $\checkmark$ & $\checkmark$ & \\
\hline Kunzea ericioides & kanuka & $\checkmark$ & $\checkmark$ & \\
\hline Laurelia novae-zelandiae & pukatea & $\checkmark$ & & \\
\hline Leptospermum scoparium & manuka & $\checkmark$ & $\checkmark$ & \\
\hline Leucopogon fasciatus & mingimingi & $\checkmark$ & & \\
\hline Lophomyrtus bullata & ramarama & $\checkmark$ & $\checkmark$ & \\
\hline Lophomyrtus obcordatum & & & $\checkmark$ & \\
\hline Lophonzia menziesii & & & $\checkmark$ & Not local \\
\hline Melicope ternata & whārangi & $\checkmark$ & $\checkmark$ & \\
\hline Melicytus chathamicus & & & $\checkmark$ & Not local \\
\hline Melicytus crassifolius & & & $\checkmark$ & Coastal \\
\hline Melicytus lanceolatus & & & $\checkmark$ & High rainfall \\
\hline Melicytus macrophyllus & & & $\checkmark$ & Not local \\
\hline Melicytus novae-zelandiae & & & $\checkmark$ & Coastal \\
\hline Melicytus obovatus & & & $\checkmark$ & Coastal \\
\hline $\begin{array}{l}\text { Melicytus ramiflorus subsp. } \\
\text { ramiflorus }\end{array}$ & māhoe, whiteywood & $\checkmark$ & $\checkmark$ & \\
\hline Meryta sinclairii & pūka & & $\checkmark$ & Not local \\
\hline Metrosideros excelsa & pohutukawa & & $\checkmark$ & Not local \\
\hline $\begin{array}{l}\text { Metrosideros excelsa } \mathrm{x} \\
\text { kermadecensis }\end{array}$ & & & $\checkmark$ & Not local \\
\hline $\begin{array}{l}\begin{array}{l}\text { Metrosideros escelsa } \mathrm{x} \\
\text { robusta }\end{array} \\
\end{array}$ & & & $\checkmark$ & \\
\hline $\begin{array}{l}\text { Metrosideros } \\
\text { kermadecensis }\end{array}$ & & & $\checkmark$ & Not local \\
\hline Metrosideros robusta & rātā & $\checkmark$ & $\checkmark$ & \\
\hline Metrosideros umbellata & & & $\checkmark$ & Not local \\
\hline Myoporum laetum & ngaio & $\checkmark$ & $\checkmark$ & \\
\hline Myoporun semotum & & & $\checkmark$ & Not local \\
\hline Myrsine australis & māpou & $\checkmark$ & $\checkmark$ & \\
\hline Myrsine salicina & toro & $\checkmark$ & $\checkmark$ & \\
\hline Muehlenbeckia astonii & & & $\checkmark$ & Coastal \\
\hline Nestegis cunninghamii & maire rau nui & $\checkmark$ & & \\
\hline
\end{tabular}




\begin{tabular}{|c|c|c|c|c|}
\hline Scientific Names & Common Names & $\begin{array}{c}\text { Buchanan } \\
1875 \& \\
\text { Myers } \\
1987 \\
\end{array}$ & $\begin{array}{l}\text { Forsyth } \\
2015\end{array}$ & Distribution \\
\hline Nestegis lanceolata & maire rauriki & & $\checkmark$ & \\
\hline Olearia avicenniifolia & & & $\checkmark$ & Mountain \\
\hline Olearia lineata & & & $\checkmark$ & Not local \\
\hline Olearia paniculata & akiraho, golden akeake & $\checkmark$ & $\checkmark$ & \\
\hline Olearia rani & heketara & $\checkmark$ & & \\
\hline Olearia solandri & & & $\checkmark$ & \\
\hline Pennantia corymbosa & kaikōmako & $\checkmark$ & $\checkmark$ & \\
\hline $\begin{array}{l}\text { Piper excelsum subsp. } \\
\text { excelsum }\end{array}$ & kawakawa & $\checkmark$ & $\checkmark$ & \\
\hline $\begin{array}{l}\text { Piper excelsum subsp. } \\
\text { peltatum }\end{array}$ & & & $\checkmark$ & Not local \\
\hline Pittosporum crassifolium & karo & & $\checkmark$ & Not local \\
\hline Pittosporum cornifolium & tāwhiri karo & & $\checkmark$ & Perching \\
\hline Pittosporum eugenioides & tarata, lemonwood & $\checkmark$ & $\checkmark$ & \\
\hline Pittosporum obcordatum & & & $\checkmark$ & Not local \\
\hline Pittosporum ralphii & karo & $\checkmark$ & $\checkmark$ & Not local \\
\hline Pittosporum sp. & & & $\checkmark$ & \\
\hline Pittosporum tenuifolium & kōhūhū & $\checkmark$ & $\checkmark$ & \\
\hline Planchonella costata & & & $\checkmark$ & Not local \\
\hline $\begin{array}{l}\text { Pomaderris apetala subsp. } \\
\text { maritima }\end{array}$ & tainui & $\checkmark$ & $\checkmark$ & \\
\hline Pouzolzia australis & & & $\checkmark$ & Not local \\
\hline Pseudopanax arboreus & whauwhaupaku, five finger & $\checkmark$ & $\checkmark$ & \\
\hline $\begin{array}{l}\text { Pseudopanax colensoi var. } \\
\text { colensoi }\end{array}$ & & & $\checkmark$ & Mountain \\
\hline Pseudopanax crassifolius & horoeka, lancewood & $\checkmark$ & $\checkmark$ & \\
\hline $\begin{array}{l}\text { Pseudopanax crassifolius } \mathrm{x} \\
\text { lessonii }\end{array}$ & hybrid pseudopanax & & $\checkmark$ & \\
\hline Pseudopanax lessonii & & & $\checkmark$ & Not local \\
\hline Pseudowintera axillaris & horopito & $\checkmark$ & & \\
\hline Raukawa edgerleyi & raukawa & $\checkmark$ & & \\
\hline Schefflera digitata & patē & $\checkmark$ & $\checkmark$ & \\
\hline Sophora microphylla & kōwhai & & $\checkmark$ & \\
\hline Sophora microphylla $x$ & & & $\checkmark$ & \\
\hline Sophora molloyi & & & $\checkmark$ & Coastal \\
\hline Sophora tetraptera & & & $\checkmark$ & Not local \\
\hline Streblus banksii & $\begin{array}{l}\text { tūrepo, large-leaved milk } \\
\text { tree }\end{array}$ & & $\checkmark$ & \\
\hline Streblus heterophyllus & $\begin{array}{l}\text { tūrepo, small-leaved milk } \\
\text { tree }\end{array}$ & & $\checkmark$ & \\
\hline Syzygium maire & maire tawake & & $\checkmark$ & \\
\hline Veronica ligustrifolia & & & $\checkmark$ & Not local \\
\hline
\end{tabular}




\begin{tabular}{|l|l|c|c|l|}
\hline Scientific Names & Common Names & $\begin{array}{c}\text { Buchanan } \\
\mathbf{1 8 7 5} \text { \&yers } \\
\mathbf{1 9 8 7}\end{array}$ & $\begin{array}{c}\text { Forsyth } \\
\mathbf{2 0 1 5}\end{array}$ & Distribution \\
\hline Veronica parviflora & $\begin{array}{l}\text { koromiko taranga, tree } \\
\text { hebe }\end{array}$ & & $\checkmark$ & \\
\hline Veronica sp. & & & $\checkmark$ & \\
\hline Veronica speciosa & koromiko & $\checkmark$ & $\checkmark$ & Coastal \\
\hline Veronica stricta var. stricta & pūriri & $\checkmark$ & $\checkmark$ & Not local \\
\hline Vitex lucens & kāmahi & $\checkmark$ & & \\
\hline Weinmannia racemosa & & & & \\
\hline & & $\checkmark$ & $\checkmark$ & \\
\hline TREE FERNS & ponga & $\checkmark$ & $\checkmark$ & \\
\hline Cyathea dealbata & mamaku & & $\checkmark$ & \\
\hline Cyathea medullaris & whekī & & $\checkmark$ & \\
\hline Dicksonia squarrosa & & & \\
\hline
\end{tabular}




\section{COMPARISON OF CAMPUS INDIGENOUS SPECIES WITH A CHECKLIST FOR WAIMAPIHI RESERVE, ARO VALLEY}

This species checklist was created during a field trip by the Wellington Botanical Society to Waimapihi Reserve on 22 January 2007. This reserve lies less than one kilometre from the Victoria University Kelburn campus. The species mix in this regenerating secondary broadleaf podocarp forest is representative of Wellington lowland forest that has been managed by volunteers for restoration purposes over three decades. It comprises a mix of naturally regenerating and planted species and includes some species that are not local to Wellington City.

\begin{tabular}{|c|c|c|c|}
\hline SCIENTIFIC NAME & COMMON NAME & WAIMAIPIHI & VUW 14-15 \\
\hline \multicolumn{4}{|l|}{$\begin{array}{l}\text { INDIGENOUS } \\
\text { GYMNOSPERMS }\end{array}$} \\
\hline Agathis australis & kauri & $\checkmark$ & $\checkmark$ \\
\hline Dacrycarpus dacrydioides & kahikatea & $\checkmark$ & $\checkmark$ \\
\hline Dacrydium cupressinum & rimu & $\checkmark$ & \\
\hline Libocedrus plumosa & & & $\checkmark$ \\
\hline Phyllocladus trichomanoides & tānekaha, celery pine & $\checkmark$ & $\checkmark$ \\
\hline Podocarpus totara var. totara & tōtara & $\checkmark$ & $\checkmark$ \\
\hline Prumnopitys ferruginea & miro & $\checkmark$ & $\checkmark$ \\
\hline Prumnopitys taxifolia & mataī & $\checkmark$ & $\checkmark$ \\
\hline \multicolumn{4}{|l|}{ MONOCOT TREES } \\
\hline Cordyline australis & tī kōuka, cabbage tree & $\checkmark$ & $\checkmark$ \\
\hline Rhopalostylus sapida & nīkau & $\checkmark$ & $\checkmark$ \\
\hline \multicolumn{4}{|l|}{\begin{tabular}{lll|} 
DICOT & TREES & AND \\
SHRUBS & & \\
\end{tabular}} \\
\hline Ackama rosifolia & & & $\checkmark$ \\
\hline Alectryon excelsus & tītoki & $\checkmark$ & $\checkmark$ \\
\hline Aristotelia serrata & makomako, wineberry & $\checkmark$ & $\checkmark$ \\
\hline Brachyglottis repanda & rangiora & $\bar{\checkmark}$ & $\checkmark$ \\
\hline Carmichaelia australis & common broom & $\checkmark$ & \\
\hline Carmichaelia sp. & & & $\checkmark$ \\
\hline Carpodetus serratus & putaputawētā, marbleleaf & & $\checkmark$ \\
\hline
\end{tabular}




\begin{tabular}{|c|c|c|c|}
\hline SCIENTIFIC NAME & COMMON NAME & WAIMAIPIHI & VUW 14-15 \\
\hline Coprosma areolata & & $\checkmark$ & \\
\hline Coprosma foetidissima & stinkwood & & $\checkmark$ \\
\hline Coprosma grandifolia & kanono & $\checkmark$ & $\checkmark$ \\
\hline $\begin{array}{l}\text { Coprosma macrocarpa } \\
\text { subsp. macrocarpa }\end{array}$ & & & $\checkmark$ \\
\hline Coprosma microcarpa & & & $\checkmark$ \\
\hline Coprosma parviflora & & & $\checkmark$ \\
\hline $\begin{array}{l}\text { Coprosma propinqua var. } \\
\text { propinqua }\end{array}$ & mingimingi & $\checkmark$ & $\checkmark$ \\
\hline Coprosma repens & taupata & $\checkmark$ & $\checkmark$ \\
\hline $\begin{array}{l}\text { Coprosma repens aff. Poor } \\
\text { Knights }\end{array}$ & & & $\checkmark$ \\
\hline Coprosma rhamnoides & & $\checkmark$ & $\checkmark$ \\
\hline Coprosma robusta & karamū & $\checkmark$ & $\checkmark$ \\
\hline $\begin{array}{lll}\begin{array}{l}\text { Coprosma } \\
\text { propinqua }\end{array} & \text { robusta } & \mathrm{x} \\
\end{array}$ & & & $\checkmark$ \\
\hline Coprosma sp. & & & $\checkmark$ \\
\hline Coprosma virescens & & & $\checkmark$ \\
\hline Corokia buddleioides & korokio & & $\checkmark$ \\
\hline Corokia cotoneaster & korokio & $\checkmark$ & $\checkmark$ \\
\hline Corokia macrocarpa & korokio & $\checkmark$ & $\checkmark$ \\
\hline Corynocarpus laevigatus & karaka & & $\checkmark$ \\
\hline Dodonaea viscosa & akeake & $\checkmark$ & $\checkmark$ \\
\hline Dysoxolum spectabile & kohekohe & $\checkmark$ & \\
\hline $\begin{array}{l}\begin{array}{l}\text { Elaeocarpis dentatus var. } \\
\text { dentatus }\end{array} \\
\end{array}$ & hīnau & $\checkmark$ & $\checkmark$ \\
\hline Entelia arborescens & whau & $\checkmark$ & $\checkmark$ \\
\hline Fuchsia excorticata & kōtukutuku, tree fuchsia & $\checkmark$ & \\
\hline Fuscospora fusca & red beech & $\checkmark$ & \\
\hline Fuscospora solandri & black beech & $\checkmark$ & $\checkmark$ \\
\hline Fuscospora truncata & hard beech & $\checkmark$ & $\checkmark$ \\
\hline $\begin{array}{l}\text { Geniostoma rupestre var. } \\
\text { ligustrifolium }\end{array}$ & hangehange & $\checkmark$ & $\checkmark$ \\
\hline Griselinia littoralis & papauma, broadleaf & $\checkmark$ & $\checkmark$ \\
\hline Hedycarya arborea & porokaiwhiri, pigeonwood & & $\checkmark$ \\
\hline Hoheria populnea & houhere, lacebark & $\checkmark$ & $\checkmark$ \\
\hline Hoheria sexstylosa & houhere, lacebark & & $\checkmark$ \\
\hline Knightia excelsa & rewarewa & $\checkmark$ & $\checkmark$ \\
\hline Kunzea ericioides & kanuka & & $\checkmark$ \\
\hline Leptospermum scoparium & manuka & $\checkmark$ & $\checkmark$ \\
\hline Lophomyrtus bullata & ramarama & & $\checkmark$ \\
\hline
\end{tabular}




\begin{tabular}{|c|c|c|c|}
\hline SCIENTIFIC NAME & COMMON NAME & WAIMAIPIHI & VUW 14-15 \\
\hline Lophomyrtus obcordatum & & & $\checkmark$ \\
\hline Lophonzia menziesii & silver beech & $\checkmark$ & $\checkmark$ \\
\hline Melicope ternata & whārangi & $\checkmark$ & $\checkmark$ \\
\hline Melicytus chathamicus & & & $\checkmark$ \\
\hline Melicytus crassifolius & & & $\checkmark$ \\
\hline Melicytus lanceolatus & & & $\checkmark$ \\
\hline Melicytus macrophyllus & & & $\checkmark$ \\
\hline Melicytus novae-zelandiae & & & $\checkmark$ \\
\hline Melicytus obovatus & & & $\checkmark$ \\
\hline $\begin{array}{l}\text { Melicytus ramiflorus subsp. } \\
\text { ramiflorus }\end{array}$ & māhoe, whiteywood & $\checkmark$ & $\checkmark$ \\
\hline Meryta sinclairii & pūka & $\checkmark$ & $\checkmark$ \\
\hline Metrosideros excelsa & pohutukawa & $\checkmark$ & $\checkmark$ \\
\hline $\begin{array}{l}\text { Metrosideros excelsa } \mathrm{x} \\
\text { kermadecensis }\end{array}$ & & & $\checkmark$ \\
\hline $\begin{array}{l}\begin{array}{l}\text { Metrosideros } \\
\text { robusta }\end{array} \\
\text { roscelsa } \\
\text { x }\end{array}$ & & & $\checkmark$ \\
\hline Metrosideros kermadecensis & & & $\checkmark$ \\
\hline Metrosideros robusta & rātā & & $\checkmark$ \\
\hline Metrosideros umbellata & & & $\checkmark$ \\
\hline Myoporum laetum & ngaio & $\checkmark$ & $\checkmark$ \\
\hline Myoporun semotum & & & $\checkmark$ \\
\hline Myrsine australis & māpou & $\checkmark$ & $\checkmark$ \\
\hline Myrsine salicina & toro & $\checkmark$ & $\checkmark$ \\
\hline Muehlenbeckia astonii & & $\checkmark$ & $\checkmark$ \\
\hline Nestegis lanceolata & maire rauriki & $\checkmark$ & $\checkmark$ \\
\hline Olearia avicenniifolia & & & $\checkmark$ \\
\hline Olearia lineata & & & $\checkmark$ \\
\hline Olearia paniculata & akiraho, golden akeake & & $\checkmark$ \\
\hline Olearia solandri & & & $\checkmark$ \\
\hline Olearia sp. & & & $\checkmark$ \\
\hline Pennantia corymbosa & kaikōmako & $\checkmark$ & $\checkmark$ \\
\hline $\begin{array}{l}\text { Piper excelsum subsp. } \\
\text { excelsum }\end{array}$ & kawakawa & $\checkmark$ & $\checkmark$ \\
\hline $\begin{array}{l}\text { Piper excelsum subsp. } \\
\text { psittacorum }\end{array}$ & kawakawa & & $\checkmark$ \\
\hline Pittosporum cornifolium & tāwhiri karo & & $\checkmark$ \\
\hline Pittosporum crassifolium & & $\checkmark$ & $\checkmark$ \\
\hline Pittosporum eugenioides & tarata, lemonwood & $\checkmark$ & $\checkmark$ \\
\hline Pittosporum obcordatum & & & $\checkmark$ \\
\hline Pittosporum ralphii & karo & $\checkmark$ & $\checkmark$ \\
\hline
\end{tabular}




\begin{tabular}{|c|c|c|c|}
\hline SCIENTIFIC NAME & COMMON NAME & WAIMAIPIHI & VUW 14-15 \\
\hline Pittosporum sp. & & & $\checkmark$ \\
\hline Pittosporum tenuifolium & kōhūhū & $\checkmark$ & $\checkmark$ \\
\hline $\begin{array}{l}\text { Plagianthus regius subsp. } \\
\text { regius }\end{array}$ & mānatu & $\checkmark$ & \\
\hline Planchonella costata & & & $\checkmark$ \\
\hline $\begin{array}{l}\text { Pomaderris apetala subsp. } \\
\text { maritima }\end{array}$ & tainui & & $\checkmark$ \\
\hline Pouzolzia australis & & & $\checkmark$ \\
\hline Pseudopanax arboreus & whauwhaupaku, five finger & $\checkmark$ & $\checkmark$ \\
\hline $\begin{array}{l}\text { Pseudopanax colensoi var. } \\
\text { colensoi }\end{array}$ & & & $\checkmark$ \\
\hline Pseudopanax crassifolius & horoeka, lancewood & $\checkmark$ & $\checkmark$ \\
\hline $\begin{array}{l}\text { Pseudopanax crassifolius } \mathrm{x} \\
\text { lessonii }\end{array}$ & hybrid pseudopanax & & $\checkmark$ \\
\hline Pseudopanax ferox & & $\checkmark$ & $\checkmark$ \\
\hline Schefflera digitata & patē & $\checkmark$ & $\checkmark$ \\
\hline Sophora microphylla & kōwhai & $\checkmark$ & $\checkmark$ \\
\hline Sophora microphylla $\mathrm{x}$ & & & $\checkmark$ \\
\hline Sophora molloyi & & & $\checkmark$ \\
\hline Sophora prostrata & & $\checkmark$ & \\
\hline Sophora tetraptera & & $\checkmark$ & $\checkmark$ \\
\hline Streblus banksii & tūrepo, large-leaved milk tree & & $\checkmark$ \\
\hline Streblus heterophyllus & tūrepo, small-leaved milk tree & & $\checkmark$ \\
\hline Syzygium maire & maire tawake & & $\checkmark$ \\
\hline Teucridium parvifolium & & & $\checkmark$ \\
\hline Veronica cv. wiri & & & $\checkmark$ \\
\hline Veronica ligustrifolia & & & $\checkmark$ \\
\hline Veronica ligustrifolia & & & $\checkmark$ \\
\hline Veronica parviflora & koromiko taranga, tree hebe & & $\checkmark$ \\
\hline Veronica sp. & & & $\checkmark$ \\
\hline Veronica speciosa & & & $\checkmark$ \\
\hline Veronica stricta var. stricta & koromiko & $\checkmark$ & $\checkmark$ \\
\hline Vitex lucens & pūriri & $\checkmark$ & $\checkmark$ \\
\hline Weinmannia racemosa & kāmahi & $\checkmark$ & \\
\hline \multicolumn{4}{|l|}{ FERNS } \\
\hline Cyathea dealbata & ponga & $\checkmark$ & $\checkmark$ \\
\hline Cyathea medullaris & mamaku & $\checkmark$ & $\checkmark$ \\
\hline Dicksonia squarrosa & whekī & & $\checkmark$ \\
\hline
\end{tabular}




\section{ETHICS COMMITTEE APPROVAL FOR AN ELICITATION SURVEY}

TE WHARE WX̃NANGA O TE ÖPOKO O TE TKA A MŘUI

\section{MEMORANDUM

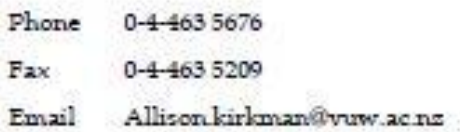

\begin{tabular}{l|l}
\hline TO & Frances Forsyth \\
\hline COPY TO & Wayne Linklater \\
\hline FROM & Dr Allison Kirkman, Convener, Human Ethics Committee \\
\hline
\end{tabular}

\begin{tabular}{l|l}
\hline DATE & 13 March 2015 \\
\hline PAGES & 1 \\
\hline
\end{tabular}

\begin{tabular}{l|l}
\hline SUBJECT & $\begin{array}{l}\text { Ethics Approval: } 21538 \\
\text { Biodiversity values of campus green space: opinions held by staff } \\
\text { at the VUW Kellburn and Karori campuses }\end{array}$ \\
\hline
\end{tabular}

Thank you for your application for ethical approval, which has now been considered by the Standing Committee of the Human Ethics Committee.

Your application has been approved from the above date and this approval continues until 31 December 2015. If your data collection is not completed by this date you should apply to the Human Ethics Committee for an extension to this approval.

Best wishes with the research.

Allison Kirkman

Human Ethics Committee 


\title{
ELICITATION SURVEY QUESTIONS
}

\author{
VICTORIA UNIVERSITY OF WELLINGTON \\ Te Whare Wānanga o te Ūpoko o te Ika a Māui
}

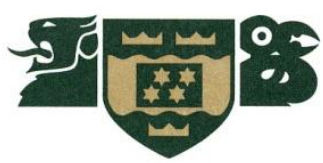

\section{QUESTIONS REGARDING GREEN SPACE VALUES HELD BY STAFF AT THE VUW KELBURN AND KARORI CAMPUSES}

\section{Introduction}

My name is Frances Forsyth and I am a MSc student with the Centre for Biodiversity and Restoration Ecology, Victoria University. I would like your help with this pilot study to find out from people working on the Kelburn and Karori campuses what they think campus green space is, how they use it and its importance. Results from this study will help better understand peoples' attitudes towards the green space on campus and may contribute to campus planning.

Your have been chosen from people employed by the University and the information you provide will be anonymous. This research has been approved by the Victoria University Ethics Committee. The results of this interview will be used only for this study and will form the basis of my masters' thesis research. This survey is voluntary.

I would like to start by asking you some demographic questions relevant to the campus community and then to talk about campus green space. I would like to reassure you that your response to this survey will be anonymous. 


\section{Questions}

1.1 Are you:

$\square$ Female $\quad \square$ Male

1.2 What age band do you belong to?
$18-25$
$\square 26-35$
$\square 36-50$
$51-70$
$\square$ over 70

1.3 What is your role at the university? $\square$ Administrative $\square$ Support \& Technical $\square$ Academic

2.1 What do you understand the phrase campus green space to mean?

2.2 What do you use campus green space for?

2.3 What campus green space do you use?

2.4 What about campus green space is important to you?

2.5 Is there anything else you would like to tell me about campus green space?

\section{SCHOOL OF BIOLOGICAL SCIENCES \\ Te Kura Mātauranga Koiora \\ FACULTY OF SCIENCE \\ Te Wāhanga Pūtaiao \\ P.O. Box 600, Wellington, New Zealand}

Telephone +64-4-463-5339, Facsimile +64-4-463-5331

Email Biosci@vuw.ac.nz 


\section{PERMISSION FORM FOR ELICITATION SURVEY}

\section{PARTICIPANTS}

\section{Consent Form for Biodiversity Elicitation Survey}

My name is Frances Forsyth and I am a MSc student with the Centre for Biodiversity and Restoration Ecology, Victoria University. I would like your help with this pilot study to find out from people working on the Kelburn and Karori campuses what they think campus green space is, how they use it and its importance. Results from this study will help better understand peoples' attitudes towards the green space on campus and may contribute to campus planning.

Your have been chosen from people employed by the University and the information you provide will be anonymous. This research has been approved by the Victoria University Ethics Committee. The results of this interview will be used only for this study and will form the basis of my masters' thesis research. This survey is voluntary.

\section{Permission}

I give permission for this interview to be recorded.

Participant name

Participant signature

Date. ...

I give permission for my responses to be used in the study of campus green space. I understand my answers will be anonymous.

Participant name

Participant

signature.

Date. 


\section{STAFF EMAIL SURVEY QUESTIONS}

\section{Values of workplace greenspace - staff survey}

Q1. The view from my office is mostly of

1st choice 2nd choice 3rd choice

- Campus green space

- Building/s

- Road/footpath

- Neighbouring houses and gardens

- Harbour

- Sky

Q2. What I like best about the view from my office is

Q3. I would prefer it if the view from my office included more

Tick all that apply

- Campus green space

- Building/s

- Road/footpath

- Neighbouring houses and gardens

- Harbour

- Sky

Q4. During my working day my favourite outdoor place to go is here

Use your mouse to scroll/zoom/click on the map to find and record your favourite place. The latitude and longitude details will show automatically. Don't worry about altitude and accuracy. If you make a mistake delete the latitude and longitude coordinates and start again.

latitude $\left(\mathrm{x} . \mathrm{y}^{\circ}\right) \quad$ longitude $\left(\mathrm{x} . \mathrm{y}^{\circ}\right)$ 


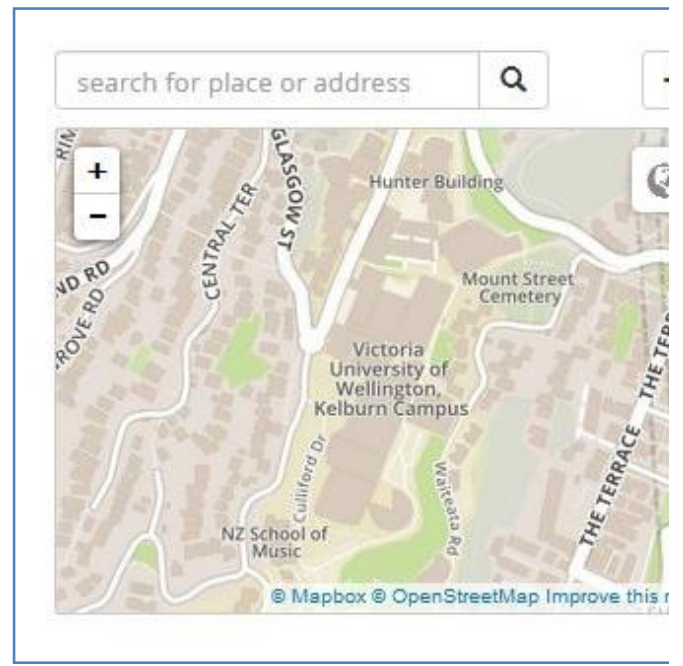

Q5. Why do I go there?

E.g. to relax, to eat lunch

Q6. What I like about this place is

Write about what makes this place preferable to you than some other place

Q7. In the warmer months of the year I go to my favourite place

Choose one option

- Several times a day

- Most days

- About once a week

- Several times a month

- About once a month

- Rarely

Q8. In the cooler months of the year I go to my favourite place

Choose one option

- Several times a day

- Most days

- About once a week

- Several times a month

- About once a month 


\section{Q9. My second most favourite outdoor place to go is here}

Use your mouse to scroll/zoom/click on the map to find and record your favourite place. The latitude and longitude details will show automatically. Don't worry about altitude and accuracy. If you make a mistake delete the latitude and longitude coordinates and start again.

latitude $\left(\mathrm{x} . \mathrm{y}^{\circ}\right) \quad$ longitude $\left(\mathrm{x} . \mathrm{y}^{\circ}\right)$

altitude $(\mathrm{m}) \quad$ accuracy $(\mathrm{m})$

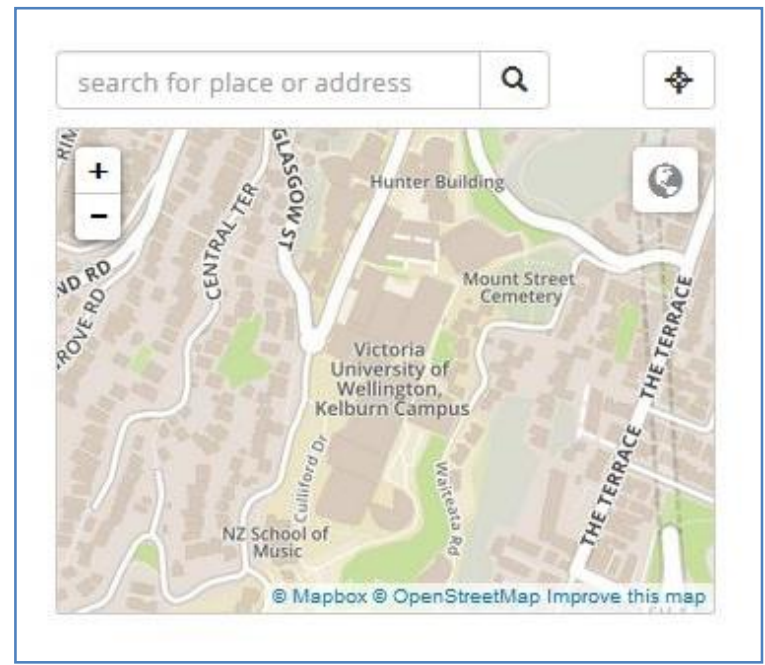

Q10. Why do I go there?

E.g. to relax, to eat lunch

\section{Q11. What I like about this place is}

Write about what makes this place preferable to you than some other place

Q12. In the warmer months of the year I go to my second favourite place

Choose one option

- Several times a day

- Most days

- About once a week

- Several times a month

- About once a month

- Rarely

Q13. In the cooler months of the year I go to my second favourite place

Choose one option

- Several times a day 
- Most days

- About once a week

- Several times a month

- About once a month

- Rarely

\section{Q14. Regarding your access to Kelburn campus green space}

Access means you can get to green space and be in it

- I have as much access to campus green space as I want

- I have less access to campus green space than I would like

- I do not have access to campus green space

Q15. What would give you greater access to Kelburn campus green space?

\section{Q16. Regarding Kelburn campus green space: I would like more}

Tick all that apply

- Native birds

- Seats

- Large trees

- Information about plants and animals on campus

- Collections of New Zealand plants

- Flowering plants and trees

- Information about campus walkways and seats

- Nicely maintained gardens

- Lawns

- Native plants

- Plants from other countries

- Wilderness areas

- Confidence that I will be safe from dangerous plants and animals

- Sunny sheltered places to go

- None of the above

Q17. Regarding campus green space: I would like fewer/less

Tick all that apply

- Birds from overseas

- Seats

- Large trees

- Information about plants and animals on campus

- Collections of New Zealand plants

- Flowering plants and trees

- Information about campus walkways and seats 
- Nicely maintained gardens

- Lawns

- Native plants

- Plants from other countries

- Wilderness areas

- Fear of dangerous plants and animals

- Sunny sheltered places to go

- None of the above

\section{Q18. My usual workplace on Kelburn campus is here}

Click on a building on the map to show where your office is. If you make a mistake delete the latitude and longitude coordinates and start again

latitude (x. $\left.\mathrm{y}^{\circ}\right) \quad$ longitude $\left(\mathrm{x} . \mathrm{y}^{\circ}\right)$

altitude (m) accuracy (m)

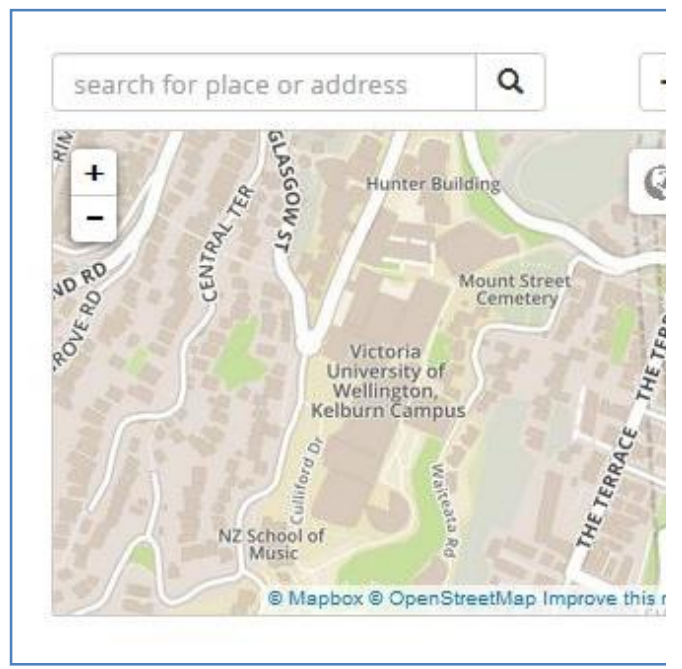


Q19. I describe myself as

- Female

- Male

Q20. My age is

- 15-19

- 20-29

- 30-39

- 40-49

- 50-59

- 60-69

- 70 and above

Q21. My role at university is

- Administrative

- Support (campus services)

- Technical (teaching and research technician)

- Academic

Q22. I have worked at the campus for

- Less than one year

- 1-3 years

- 4-10 years

- More than 10 years 


\section{STUDENT EMAIL SURVEY QUESTIONS}

\section{Values of workplace greenspace - student survey}

\section{Q1. During my day at university in Kelburn my favourite outdoor place to go is here}

Use your mouse to scroll/zoom/click on the map to find and record your favourite place. The latitude and longitude details will show automatically. Don't worry about altitude and accuracy. If you make a mistake delete the latitude and longitude coordinates and start again.

latitude (x. $\left.\mathrm{y}^{\circ}\right) \quad$ longitude $\left(\mathrm{x} . \mathrm{y}^{\circ}\right)$

altitude (m) accuracy (m)

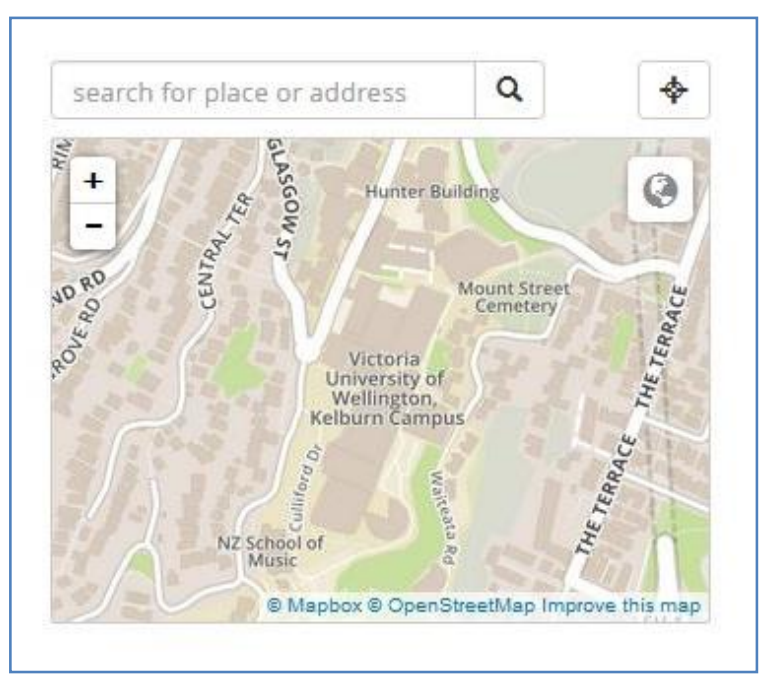

\section{Q2. Why do I go there?}

E.g. to relax, to eat lunch

\section{Q3. What I like about this place is}

Write about what makes this place preferable to you than some other place

Q4. In the warmer months of the year I go to my favourite place

Choose one option

- Several times a day

- Most days 
- About once a week

- Several times a month

- About once a month

- Rarely

\section{Q5. In the cooler months of the year I go to my favourite place}

Choose one option

- Several times a day

- Most days

- About once a week

- Several times a month

- About once a month

- Rarely

\section{Q6. My second most favourite outdoor place to go is here}

Use your mouse to scroll/zoom/click on the map to find and record your favourite place. The latitude and longitude details will show automatically. Don't worry about altitude and accuracy. If you make a mistake delete the latitude and longitude coordinates and start again.

latitude (x. $\left.\mathrm{y}^{\circ}\right) \quad$ longitude $\left(\mathrm{x} . \mathrm{y}^{\circ}\right)$

altitude (m) accuracy (m)

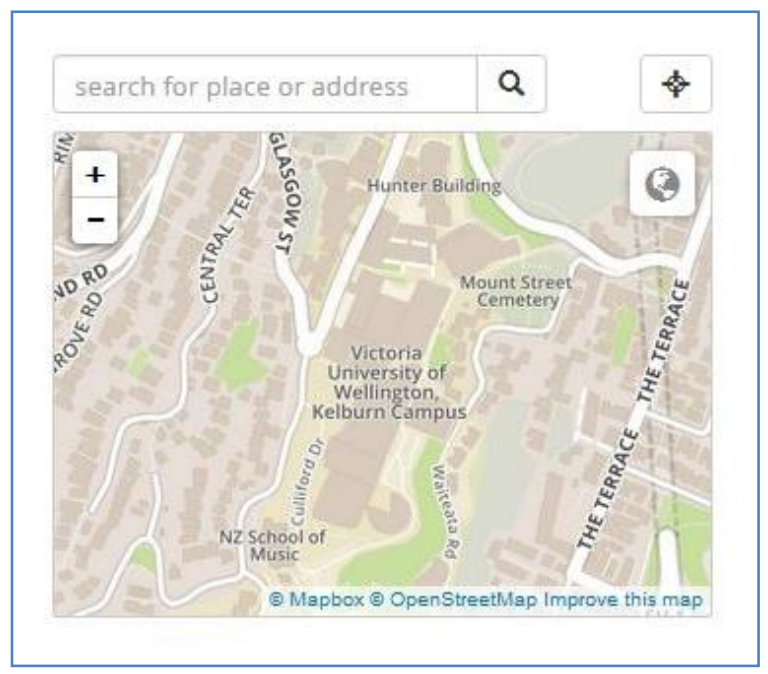




\section{Q7. Why do I go there?}

E.g. to relax, to eat lunch

Q8. What I like about this place is

Write about what makes this place preferable to you than some other place

Q9. In the warmer months of the year I go to my second favourite place Choose one option

- Several times a day

- Most days

- About once a week

- Several times a month

- About once a month

- Rarely

Q10. In the cooler months of the year I go to my second favourite place Choose one option

- Several times a day

- Most days

- About once a week

- Several times a month

- About once a month

- Rarely

\section{Q11. Regarding your access to Kelburn campus green space}

Access means you can get to green space and be in it

- I have as much access to campus green space as I want

- I have less access to campus green space than I would like

- I do not have access to campus green space

Q12. What would give you greater access to Kelburn campus green space?

Q13. Regarding Kelburn campus green space: I would like more Tick all that apply

- Native birds

- Seats 
- Large trees

- Information about plants and animals on campus

- Collections of New Zealand plants

- Flowering plants and trees

- Information about campus walkways and seats

- Nicely maintained gardens

- Lawns

- Native plants

- Plants from other countries

- Wilderness areas

- Confidence that I will be safe from dangerous plants and animals

- Sunny sheltered places to go

- None of the above

Q14. Regarding campus green space: I would like fewer/less

Tick all that apply

- Birds from overseas

- Seats

- Large trees

- Information about plants and animals on campus

- Collections of New Zealand plants

- Flowering plants and trees

- Information about campus walkways and seats

- Nicely maintained gardens

- Lawns

- Native plants

- Plants from other countries

- Wilderness areas

- Fear of dangerous plants and animals

- Sunny sheltered places to go

- None of the above

\section{Q15. I describe myself as}

- Female

- Male

\section{Q16. My age is}

- $15-19$

- 20-29

- 30-39

- 40-49

- 50-59

- 60-69

- 70 and above 
Q17. I have studied at the campus for

- Less than one year

- 1-3 years

- 4-5 years

- More than 5 years 


\section{ETHICS COMMITTEE APPROVAL FOR AN EMAIL SURVEY}

\section{MEMORANDUM}

Phone $\quad 0-4-4635205$

Email stephen markhallevuw.acna

\begin{tabular}{l|l}
\hline TO & Frances Forsyth \\
\hline COPY TO & Wayne Linklater \\
\hline FROM & Dr Stephen Marshall, Acting Convener, Human Ethics Committee \\
\hline DATE & 27 August 2015 \\
\hline PAGES & 1 \\
\hline \multicolumn{2}{|l}{} \\
\hline SUBJECT & $\begin{array}{l}\text { Ethics Approval: 22271 } \\
\text { VUW Kelburn Campus Green Space Values }\end{array}$ \\
\hline
\end{tabular}

Thank you for your application for ethical approval. Your application has been considered by the Acting Convener of the Human Ethics Committee and identified as research involving anonymous participation.

Your application has been approved from the above date and this approval continues until 31 December 2015 . If your data collection is not completed by this date you should apply to the Human Ethics Committee for an extension to this approval.

Best wishes with the research.

Stephen Marshall,

Acting Convener, Victoria University Human Ethics Committee 


\section{HAVE YOUR SAY TEAR TAB POSTER FOR STUDENTS}

\section{Have your \\ say \\ about campus}

\section{trees}

Do you love spending time outdoors on campus? Watching trees from a window? Walking through the campus on your way to and from university?

If you would like to influence the management of our campus gardens, take a tab from the right and go online to complete this five minute survey.

The survey will ask you questions about where you go and what you'd like to see more - and less of - in campus green space. The results will help me write a green space management plan for Campus Services.

This survey has the approval of the Victoria University Human Ethics committee (application number 0000022271).
Campus trees student survey

https://iyuiy.enketo.kobotoolbox.org/webform

Campus trees student survey

https://iyuiy.enketo.kobotoolbox.org/webform

Campus trees student survey

https://iyuiy.enketo.kobotoolbox.org/webform

Campus trees student survey

https://iyuiy.enketo.kobotoolbox.org/webform

Campus trees student survey

https://iyuiy.enketo.kobotoolbox.org/webform

Campus trees student survey

https://iyuiy.enketo.kobotoolbox.org/webform

Campus trees student survey

https://iyuiy.enketo.kobotoolbox.org/webform

Campus trees student survey

https://iyuiy.enketo.kobotoolbox.org/webform

Campus trees student survey

https://iyuiy.enketo.kobotoolbox.org/webform

Campus trees student survey

https://iyuiy.enketo.kobotoolbox.org/webform

Campus trees student survey

https://iyuiy.enketo.kobotoolbox.org/webform

Campus trees student survey

https://iyuiy.enketo.kobotoolbox.org/webform

Campus trees student survey

https://iyuiy.enketo.kobotoolbox.org/webform

Campus trees student survey

https://iyuiy.enketo.kobotoolbox.org/webform 


\section{VIC NEWS ARTICLE}

\section{Victoria's green space - you can help with research}

Ecological restoration Master's student, Frances Forsyth, from the School of Biological Sciences, is nearing the end of her research looking at the biodiversity on Victoria's campuses and how staff and students use and value green space.

As part of her research, Frances is conducting a survey (which has Human Ethics Committee approval) to investigate how staff and students use green space on Victoria's campuses and what value green space provides. It includes questions on where people go and what they would like to see more and less of in the green spaces. The results from the survey will contribute to a green space management plan which will be provided to Campus Services.

To participate in the green space survey go to: https://emsrd.enketo.kobotoolbox.org/webform

The other component of Frances' research includes the compilation of an extensive inventory of trees on Kelburn campus and a partial inventory of trees on Karori campus.

"I was not surprised by the variety of tree species that there are on the Kelburn campus. There are some quite unusual species reflecting the choices of a number of grounds superintendents and botany staff over many years. Along with these I have also found some weed species that can limit biodiversity," Frances says.

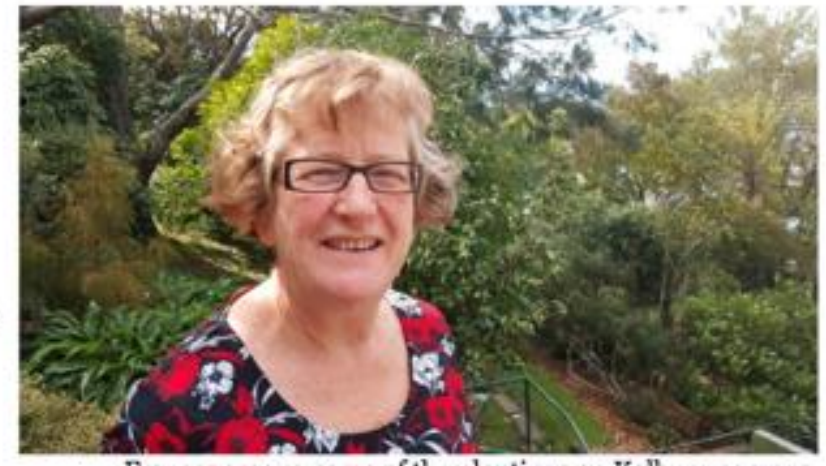

Frances among some of the plantings on Kelburn campus.

Frances' initial findings from this research have already been discussed with the grounds maintenance team that is developing a plan to support enhanced biodiversity.

This project is the result of collaboration between the Centre for Biodiversity and Restoration Ecology and Campus Services, with scholarship funding from the University's preferred office products supplier, Staples.

Promotion of the survey, and link to the survey, from the VIC News intranet newsletter for staff at Victoria University. 15 September 2015. 


\section{VUWSA FACEBOOK PAGE ABOUT THE STUDENT SURVEY}

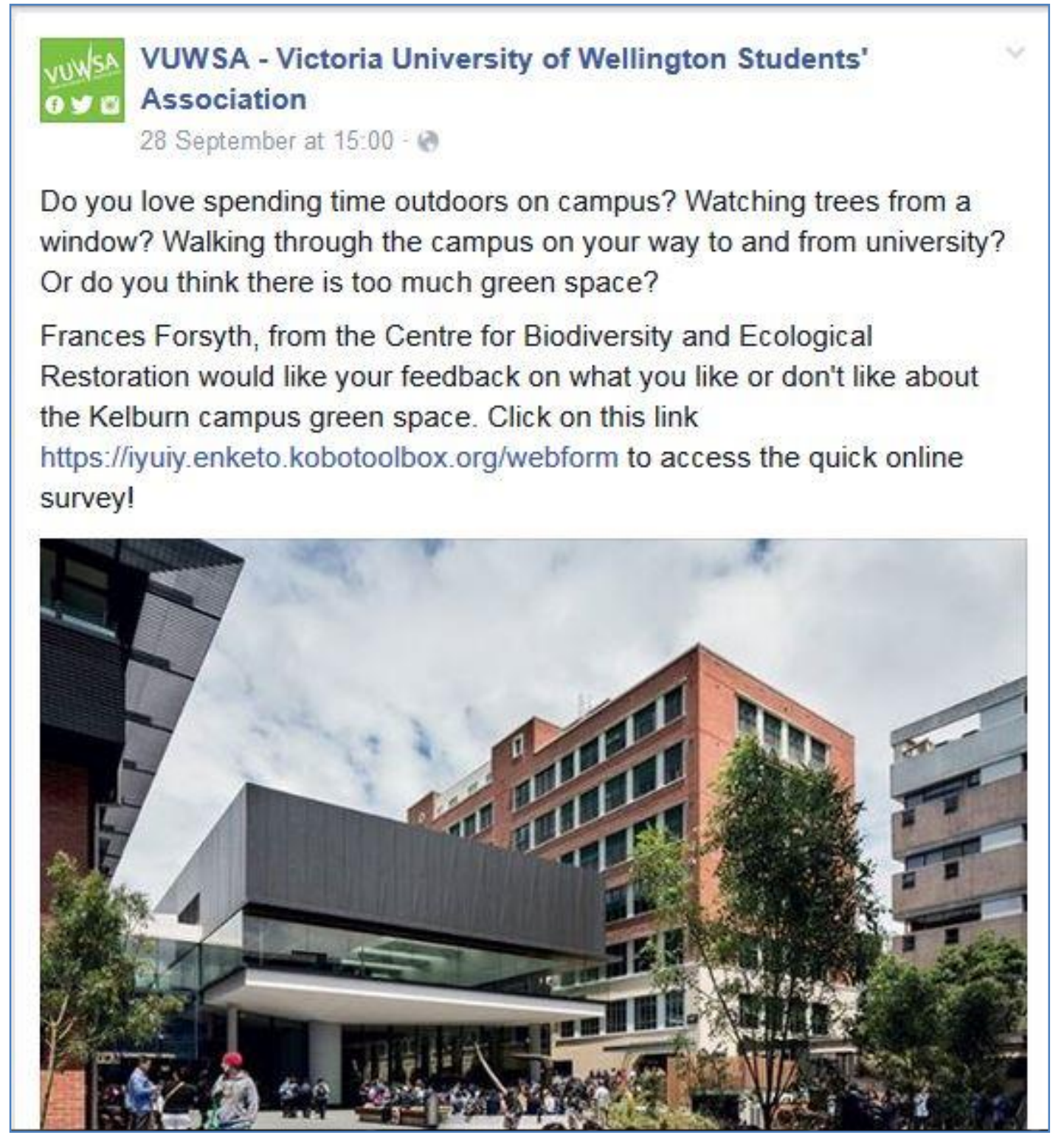

Promotion of the email survey for students on the Victoria University of Wellington Students Association Facebook page. 28 September 2015. 
STAFF/STUDENT FAVOURITE GREEN SPACE PLACES

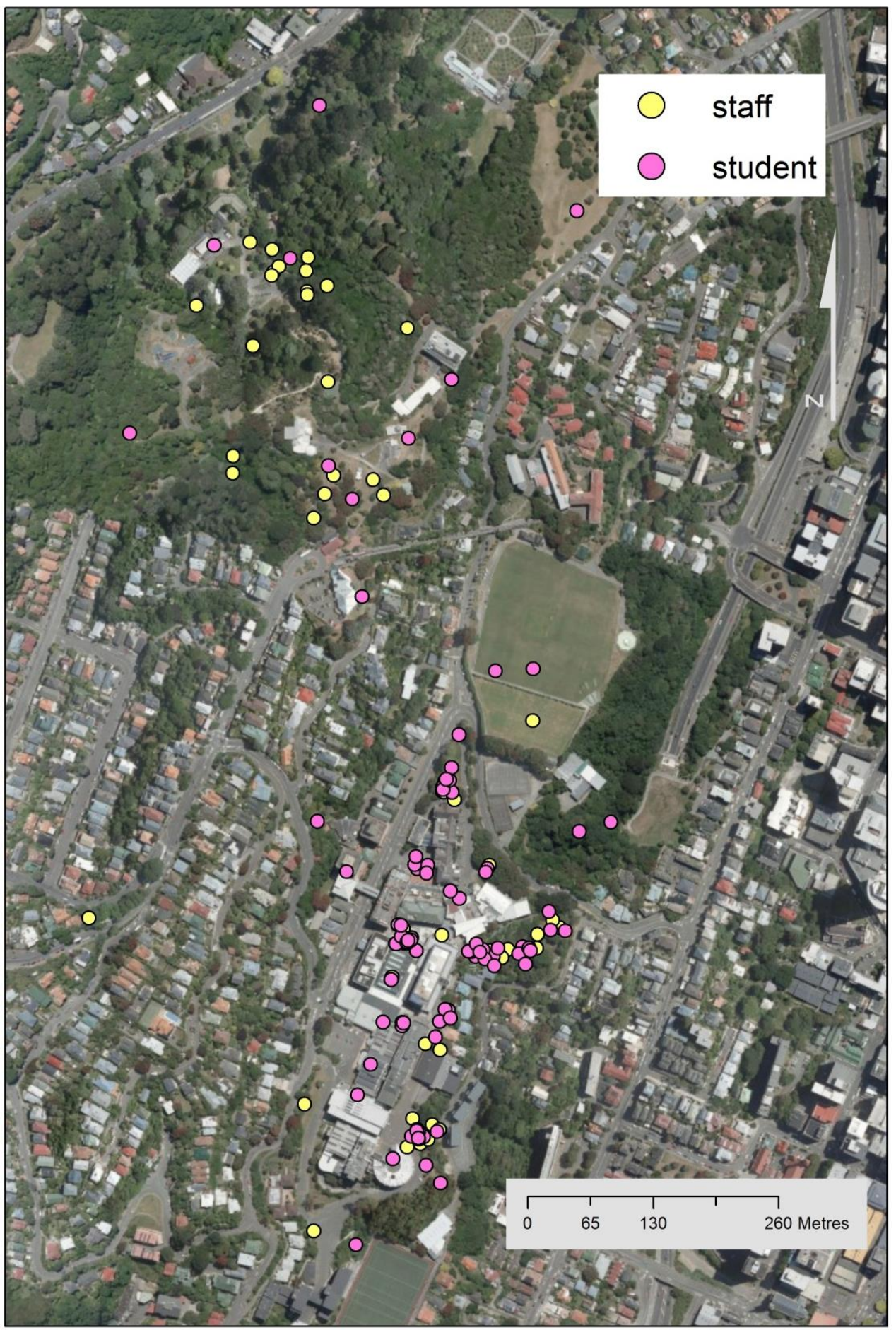

First favourite green spaces where staff and students like to go when they are at university. Hotspots include places that are close to the centre of campus and have great views. The top favourite green space for staff is the Botanic Garden. 


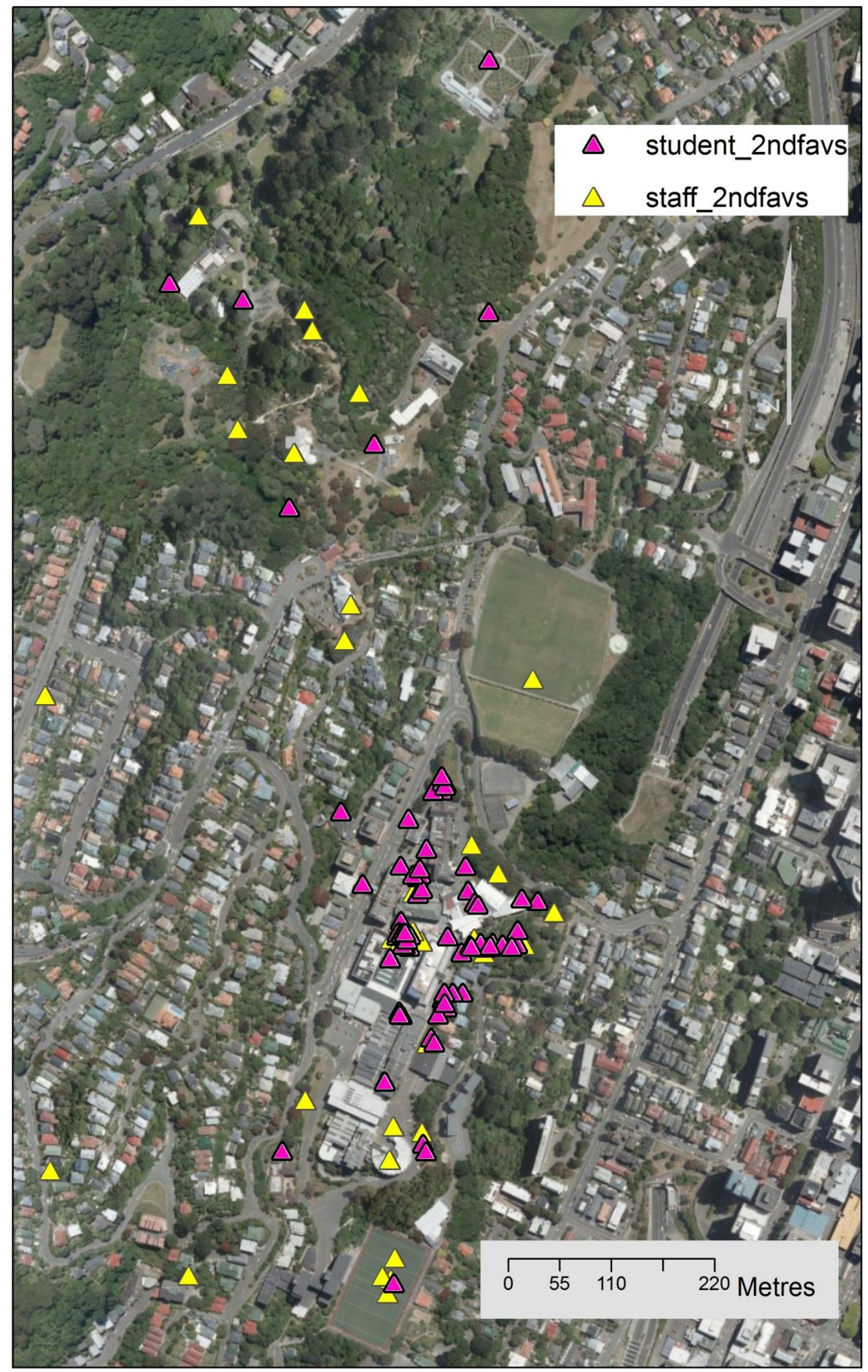

Second favourite places for students and staff. 


\section{DISTANCE STAFF ARE PREPARED TO TRAVEL TO THEIR FAVOURITE GREEN SPACE}

The pale circles with black outline are the places where staff usually work and the yellow circles with red surrounds are their favourite places to go when they are at work. The blue lines link each staff member's office with their favourite place.

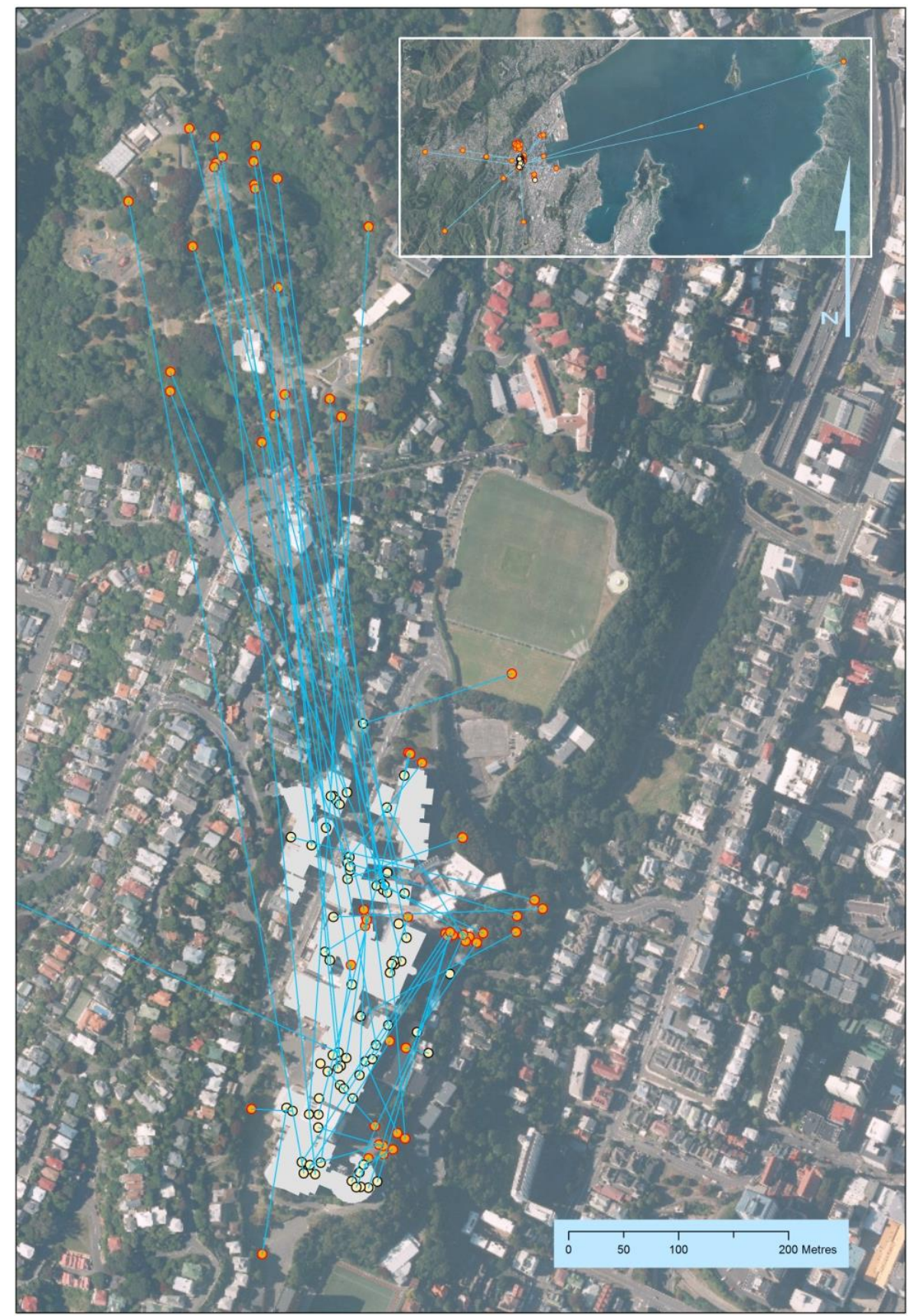


